\title{
The Evolving Role of Archaeology in Cultural Resource Management on National Historic Sites in Ontario
}

\author{
By Melissa E. Novak, Hons. B.A. \\ A thesis submitted to the Faculty of \\ Graduate Studies and Research in partial fulfillment \\ of the requirements for the degree of \\ Master of Arts \\ in Canadian Studies.
}

\author{
Carleton University \\ Ottawa, Ontario \\ February, 2007 \\ (C) Melissa E. Novak, 2007.
}




$\begin{array}{ll}\begin{array}{l}\text { Library and } \\ \text { Archives Canada }\end{array} & \begin{array}{l}\text { Bibliothèque et } \\ \text { Archives Canada }\end{array} \\ \begin{array}{l}\text { Published Heritage } \\ \text { Branch }\end{array} & \begin{array}{l}\text { Direction du } \\ \text { Patrimoine de l'édition }\end{array} \\ \begin{array}{l}\text { 395 Wellington Street } \\ \text { Ottawa ON K1A ON4 } \\ \text { Canada }\end{array} & \begin{array}{l}\text { 395, rue Wellington } \\ \text { Ottawa ON K1A 0N4 } \\ \text { Canada }\end{array}\end{array}$

Yourfile Votre référence

ISBN: 978-0-494-26964-0

Our file Notre référence

ISBN: 978-0-494-26964-0

NOTICE:

The author has granted a nonexclusive license allowing Library and Archives Canada to reproduce, publish, archive, preserve, conserve, communicate to the public by telecommunication or on the Internet, loan, distribute and sell theses worldwide, for commercial or noncommercial purposes, in microform, paper, electronic and/or any other formats.

The author retains copyright ownership and moral rights in this thesis. Neither the thesis nor substantial extracts from it may be printed or otherwise reproduced without the author's permission.
AVIS:

L'auteur a accordé une licence non exclusive permettant à la Bibliothèque et Archives Canada de reproduire, publier, archiver, sauvegarder, conserver, transmettre au public par télécommunication ou par l'Internet, prêter, distribuer et vendre des thèses partout dans le monde, à des fins commerciales ou autres, sur support microforme, papier, électronique et/ou autres formats.

L'auteur conserve la propriété du droit d'auteur et des droits moraux qui protège cette thèse. $\mathrm{Ni}$ la thèse ni des extraits substantiels de celle-ci ne doivent être imprimés ou autrement reproduits sans son autorisation.
In compliance with the Canadian

Privacy Act some supporting forms may have been removed from this thesis.

While these forms may be included in the document page count, their removal does not represent any loss of content from the thesis.
Conformément à la loi canadienne sur la protection de la vie privée, quelques formulaires secondaires ont été enlevés de cette thèse.

Bien que ces formulaires aient inclus dans la pagination, il n'y aura aucun contenu manquant. 


\begin{abstract}
This thesis argues that archaeology is a valuable tool for cultural resource management on national historic sites across Canada. It examines the historical development of the archaeology and cultural resource management and within a Canadian and North American context. The development of the Parks Canada Agency, its Cultural Resource Management Policy and the Historic Sites and Monuments Board of Canada are explored to illuminate the development of the National Historic Site system and to evaluate the contribution each organization has made to the establishment and protection of national historic sites across the country. By applying the Parks Canada Cultural Resource Management Policy to examples of the ways archaeology has been used at Fort Wellington National Historic Site and Fort Henry National Historic Site, the contribution of archaeology in the management of national historic sites will be demonstrated.
\end{abstract}




\section{Acknowledgements}

I would like to thank many people for the guidance and support they offered not only as I pursued my Master of Arts degree, but also during prior pursuits of education and experiences. Above all I would like to thank the professors within the Carleton University School of Canadian Studies. Specifically, I would like to thank my thesis supervisor Herb Stovel, who has exposed me to many new ideas and ways of seeing the world. He has always encouraged my strong desires to prove the relevance of archaeology to new audiences. Several archaeologists have also enlightened my perspectives and have shown me the practical ways that archaeology is being used throughout the province and across the world; I must thank Dr. John Triggs, Joseph Last and Henry Cary for sharing their wisdom with me.

My parents, Mary Jane and Randy Novak have always supported my inner passions and expected me to not only to succeed, but to work my very hardest. They, along with my sister, Monica, have proof-read countless essays and shown tremendous patience with me.

Elizabeth and Adam Fulton have also provided great encouragement and, in some ways acted as a catalyst for my studies at Carleton.

Finally, but no less significantly, I would like to thank Alain who has been a great source of strength to me during the completion of this thesis and who has spent many hours encouraging, editing and brainstorming with me. 


\section{Table of Contents}

$\begin{array}{lll}\text { Abstract } & \text { ii }\end{array}$

Acknowledgements

Table of Contents iv

List of Illustrations (Figures) vi

Glossary of Terms viii

Abbreviations $\quad$ xii

Introduction 1

Chapter One $\quad 9$

Archaeology in Ontario: $1945-1985$

Parks Canada and the National Historic Site System 20

$\begin{array}{ll}\text { Chapter Two } & 30\end{array}$

The Foundations of Cultural Resource Management 31

Cultural Resource Management and Parks Canada 39

$\begin{array}{ll}\text { Chapter Three } & 44\end{array}$

Charters, Standards and Guidelines: Policy Comparison from Around the World 45

The Parks Canada Cultural Resource Management Policy $\quad 52$

Fort Henry Historical Overview $\quad 58$

Fort Wellington Historical Overview 61

The Use of Archaeology on National Historic Sites: Two

Case Studies from Ontario

65

The Principles Exemplified: Understanding and Public

Benefit: Discovering New Information for Site

Interpretations and a Better Comprehension of the Social

Use of a Site

The Principles Exemplified: Understanding and Integrity: Illuminating of Methods of Historic Construction and Allowing for the Location of Previously Unrecorded Resources Furthering Appropriate Physical Interpretation of a Site

The Principles Exemplified: Respect and Value:

Enabling Appropriate Maintenance and Restoration $\quad 80$

Conclusion 
$\begin{array}{lr}\text { Figures } & 93\end{array}$

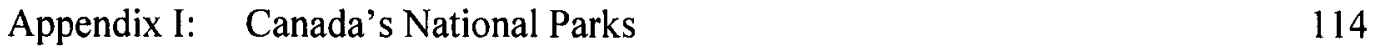

Appendix II: Expanded History: Fort Henry Redoubt and Advanced Battery

Appendix III: Charters Pertaining to Cultural Resource and Archaeological Management

International: ICOMOS Charter for the Protection and Management of the Archaeological Heritage (1990)

Australia: The Burra Charter: The Australia ICOMOS charter for the conservation of places of cultural significance (1999) (excerpts)

New Zealand: Charter for the Conservation of Places of Cultural Heritage Value (1992)

United States of America:

Charter for Historic Towns: A Preservation Charter for the Historic Towns and Areas of the United States of America (1992)

Canada: $\quad$ The Appleton Charter for the Protection and Enhancement of the Built Environment (1983) 


\section{List of Illustrations (Figures)}

Figure 1: $\quad$ Fort Henry Plan circa. 1837 with labelled fortification features. xi

Figure 2: $\quad$ Evolution of the First Fort Henry 1812 to $1832 . \quad 100$

Figure 3: $\quad$ Fort Henry after the addition of the Advanced Battery and Commissariat Ranges circa. 1837.

Figure 4: $\quad$ Plan of the Advanced Battery (Upper Fort) at Fort Henry. $\quad 102$

Aerial Photograph of the Advanced Battery at Fort Henry, 2003. 102

Figure 5: $\quad$ The Redoubt Casemates at Fort Henry during Ronald Way's 1930s reconstruction.

Figure 6: $\quad$ Mackenzie King at the opening of Fort Henry as a historic site museum August 1, 1938.

Figure 7: $\quad$ Plan of original Fort Wellington circa. 1823.

Figure 8: $\quad$ Plan of Fort Wellington after the 1838 reconstruction (circa. 1854).

Plan of Fort Wellington National Historic Site circa. 2001.

Figure 9: $\quad$ Marbles on display in the communal eating area of the second floor barracks room in the blockhouse of Fort Wellington.

Figure 10: Glass tumbler and stemmed drinking glass recovered during the latrine excavation at Fort Wellington.

Close up of Table Setting in the Officers' Dining Room display at Fort Wellington

The Officers' Dining Room display at Fort Wellington.

Figure 11: A portion of 1813 Blockhouse in relation to 1838 Blockhouse (Fort Wellington) as determined in E.A. Wylie's 1966 archaeological investigation of the interior of the Blockhouse.

Figure 12: The blockhouse, Fort Wellington, circa. 1921. 
The blockhouse, Fort Wellington, in 2006.

Figure 13: Historic shingle as discovered during a 2003 archaeological Excavation at Fort Henry.

Figure 14: The Fort Henry Commissariat Range Roof prior to restoration (circa. December 2003).

The Fort Henry Commissariat Range Roof after restoration (September, 2006).

Figure 15: The Entrance Ramp at Fort Henry.

Figure 16: $\quad$ Bowing and frost damage in the East Ramp Wall, Fort Henry prior to the 2002 stabilization.

Figure 17: $\quad$ Standing water at Fort Henry.

Figure 18: Historic Plan of the Officers' Quarters at Fort Henry, 1825.

Figure 19: Archaeological profile of Officers Quarters Foundation, Fort Henry.

Figure 20: $\quad$ Examples of Wall Plaster Fragments and associated paint colours excavated from inside Officers' Quarters, Fort Henry.

Figure 21: The installation of new infrastructure via an existing utilities corridor. 


\section{Glossary of Terms ${ }^{1}$}

\section{Advanced Battery*}

Used to refer to the whole fortified area south of the redoubt at Fort Henry, also referred to as the Upper Fort (Cary and Last, 2004: 2).

\section{Banquette}

The platform behind the parapet on which the soldier stands to fire. Immediately after firing, the soldier steps down off the platform, thus protecting himself in case of misfire. Also referred to as a fire-step (Hogg, 1975: 155).

\section{Bastion}

A projection, usually at the intersection of two walls which is arranged to give a wider range of fire or to allow firing along the main walls (New York State Division of Military and Naval Affairs, 2006).

\section{Battery of guns}

A group of cannons (Duffy, 1975: 183).

\section{Blockhouse}

A small, fortified structure used as a place of retreat within a fort (Robinson, 1977: 197).

\section{Caponnière}

A casemated defensive work which projects perpendicular across a ditch for the purpose of delivering flanking fire (Duffy, 1975: 183).

\section{Casemate* $^{*}$}

A covered chamber, usually of masonry. Defensive casemates will have loopholes from which to fire artillery (Duffy, 1975: 184).

\section{Classificatory-Descriptive Period (1840-1914)}

A distinct change of attitude in archaeological theory which is characterized by an attempt to change archaeology into a scientific, systematic discipline. The period received its name because archaeologists were attempting to scientifically classify and describe archaeological deposits (Minnesota State University, 2003).

\section{Commissariat Range}

Fortified buildings, at Fort Henry each is divided into eleven bombproof masonry chambers. These buildings were used for storage (Cary and Last, 2004: 2).

\footnotetext{
${ }^{1}$ Those definitions marked with an asterisk ( *) can be seen in Figure 1 at the end of the Glossary of Terms (p. xi). 


\section{Commemoration}

Ministerial recognition of the national significance of specific lands or waters by acquisition or by agreement, or by another means deemed appropriate within the Minister's authority for purpose of protecting and presenting heritage places and resources, reaction of a plaque or monument (Parks Canada, 1994b: 119). This definition is from the Parks Canada Guiding Principles and Operational Policies and does not directly consider early commemorations that occurred either on a local or provincial level as discussed on $p .23$.

\section{Counterscarp*}

The retaining wall on the outer side of the ditch (Duffy, 1975: 184).

\section{Ditch*}

A wide, deep trench around a defensive work (Robinson, 1977: 198).

\section{Entrance Ramp}

At Fort Henry, the entrance ramp connects the redoubt to the advanced battery. It is flanked by substantial masonry walls and connects to the counterscarp walls which encircle the redoubt in a dry ditch (Cary and Last, 2002: 4).

\section{Glacis*}

An open slope descending from the fortification which allows for a clear view of an approaching enemy and exposes the enemy to fire from the parapet (Hogg, 1975: 157).

\section{In situ}

In the natural or original position/place. In archaeology, it references the original burial context or provenience of an object (National Parks Service, 2006a).

\section{Magazine}

A place for the storage of gunpowder, arms, provisions, or other goods (Robinson, 1977: 203).

\section{Martello Tower*}

A circular masonry battery usually armed with one gun on top platform which has 360 degree coverage (New York State Division of Military and Naval Affairs, 2006).

\section{Palisade}

A high fence around the defensive enclosure often constructed of close-set, pointed wooden poles (Duffy, 1975: 185). 


\section{Parade*}

A centrally located area where troops assemble for drills and inspection (Robinson, 1977: 204)

\section{Parapet*}

A work which forms a protective wall over which defenders fired their weapons, may also refer to a perimeter wall which extends above a roof or platform (Robinson, 1977: 204).

\section{Prehistoric Archaeology}

Archaeology examining the cultures and events which occurred in any given region prior to the time for [which] written records are available (University of Manitoba, Department of Anthropology, 2006).

\section{Rampart*}

A thick wall of earth, masonry, or both, which forms the main defence of the fortress (Duffy, 1975: 185).

\section{Ravelin}

A triangular detached work, placed in front of a curtain and between two bastions and used to cover the curtain, gates and flanks of the bastions by forcing attacking troops to disperse onto either side (Duffy, 1975: 185).

\section{Redoubt*}

An enclosed fortification without bastions (Robinson, 1977: 204). At Fort Henry the redoubt is also referred to as the Lower Fort.

\section{Salvage archaeology}

The swift excavation and collection of artifacts at sites in immediate danger of destruction, usually by major land modification or construction projects (as in construction of a road or dam). Archaeologists record and recover as much of the site as they can in the brief period before it is destroyed (Archaeological Institute of America, 2006).

\section{Scarp*}

The retaining wall on the interior side of the ditch (Robinson, 1977: 204).

\section{Terreplein}

The wide, upper part of a rampart stretching from the banquette to the edge of the counterscarp (Duffy, 1975: 186).

\section{Trace}

The outline of a fortification or other structure (Robinson, 1977: 205). 
Figure 1: $\quad$ Fort Henry Plan circa. 1837 with labelled fortification features. Image from Cary and Last, 2002: 3.

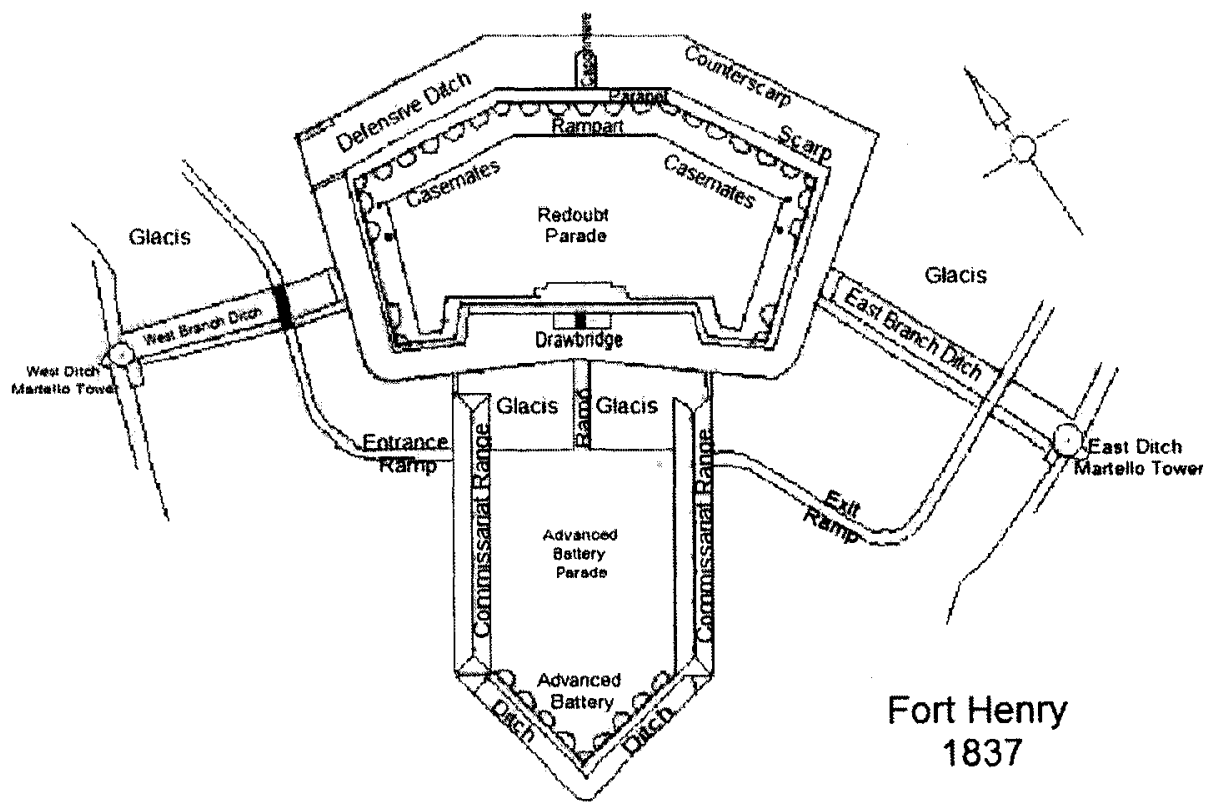




\title{
Abbreviations
}

\author{
CIS Commemorative Integrity Statement \\ CRM Cultural Resource Management \\ DND Department of National Defence (Canada) \\ HSMBC Historic Sites and Monuments Board of Canada \\ ICCROM International Centre for the Study of the Preservation and Restoration of \\ Cultural Property \\ ICOMOS International Council on Monuments and Sites \\ NEPA National Environmental Policy Act (USA) \\ NGO Non-governmental Organization \\ NHPA National Historic Preservation Act (USA) \\ NHS National Historic Site, also used: NHSC - National Historic Site of \\ Canada \\ OHA Ontario Heritage Act \\ POW Prisoner of War \\ QBC Quebec Battlefield Commission \\ RCRR Royal Canadian Rifle Regiment, also used: R.C. Rifles and RCR
}

xii 


\section{Introduction}

This paper will contend that archaeology plays an integral role within the management of national historic sites.

Growing interest in visiting historic sites attests to the importance of ensuring that management approaches present historic sites to visitors with the greatest historic fidelity possible. Statistics Canada's 2004 Canadian Travel Survey notes that heritage tourism is one of the most popular tourist activities today (Parks Canada Agency, 2003b). Heritage and cultural sites draw visitors from diverse backgrounds, ages and ethnicities, including local, domestic and foreign visitors. These visitors come in tour groups or independently, with their families or while on business trips. The one thing that these visitors have in common is their desire to "...experience the places, artifacts and activities... of the past..." (Hargrove, 2002: 10).

With one quarter of Canadians visiting a national park every year and approximately 2.5 million Canadians visiting a national historic site, the popularity of these cultural and heritage attractions is evident (Parks Canada Agency, 2004b: 3). As Canada approaches its $150^{\text {th }}$ birthday and its population continues to age, this trend towards both culture and nature-based activities is only going to become stronger. ${ }^{2}$ Unfortunately, the sites that play such an integral role in the heritage tourism industry are in jeopardy. According to Auditor General Sheila Fraser, many of Canada's national historic sites are in a poor state of repair (Office of the Auditor General of Canada, 2003). The proposed 2005 Federal Budget recognized the lack of resources that the Parks

\footnotetext{
2 The "baby boom" generation is considered important in the continued use of heritage and natural resources. Already, this group has a strong interest in visiting national parks and national historic sites and represents a potentially continuous large market for this type of tourism (Parks Canada Agency, 2003b).
} 
Canada Agency (also referred to as Parks Canada) ${ }^{3}$ and other proprietors of national historic sites have been facing since major cutbacks in the heritage sector beginning in the late 1980s (Parks Canada Agency, 2003e).

Although historic sites have enormous tourist potential, their managers must address both their continued tourism feasibility and their ultimate protection. Often these sites require preservation or restoration to enhance the physical reality of the site as well as interpretation to ensure that they are effectively understood by the tourists who visit them. The restoration and preservation of these sites incorporates the use of values-based conservation approaches to ensure a balance of use and protection. These approaches have been codified by Parks Canada around the concept of "commemorative integrity" to provide a systematic and objective way to evaluate and maintain the resource. The Commemorative Integrity Statement is a Parks Canada management tool which guides the conservation and maintenance of a site according to its historic value (Parks Canada Agency, 1998: 18). While the cost of conservation and maintenance may seem substantial, in smaller communities utilizing existing heritage resources is often much more viable than developing new attractions (Hargrove, 2002: 10).

For the first time in many years, the 2005 Federal Budget made recommendations to infuse substantial funding into the maintenance of Canada's existing national historic sites (NHS) (Department of Finance, 2005). Unfortunately, with the election of a minority Conservative Party government in early 2006, this budget was never finalized

\footnotetext{
${ }^{3}$ Following Bill C-29 (The Parks Canada Agency Act), which received Royal Assent on December 3, 1998, Parks Canada became a corporate agency under the Ministry of Canadian Heritage (House of Commons, 1998). While now formally known as the Parks Canada Agency, in practice, "the Parks Canada Agency" and "Parks Canada" continue to be used interchangeably.
} 
and the budget which superseded it failed to follow through on Fraser's recommendations (Department of Finance, 2006).

In addition to requiring substantial funding, maintaining Canada's national historic sites is a multidisciplinary practice often requiring many specialists to determine how best to protect the many aspects of each unique site (Parks Canada Agency, 2005b). Archaeology is one aspect of cultural resource management that often occurs on national historic sites in association with site preservation; it is also something that has rarely been written about in a Canadian context.

Specifically, the following thesis will examine the historical development of archaeology and cultural resource management and their use by Parks Canada on national historic sites within the province of Ontario in order to demonstrate the integral role archaeology plays on national historic sites, in the context of the application of the key principles of cultural resource management. The historical background provided within chapters one and two will provide important historical and theoretical context for two case studies which are employed within chapter three.

Both archaeology and cultural resource management have experienced an evolution of meaning since their inception. While this evolution will be explored more completely within chapters one and two, it is essential that the scope of each be defined and clearly understood within the context of the thesis and modern day associations.

In the context of this thesis, cultural resource management will be defined as the: generally accepted practices for the conservation and presentation of cultural resources, founded on principles and carried out in a practice that integrates professional, technical and administrative activities so that the historic 
value of cultural resources is taken into account in actions that might affect them.

Parks Canada, 1994b: 119.

A cultural resource includes any human work or place that has a spiritual or cultural meaning and has been determined to have historic value. Cultural resources also include physical remains and artifacts (Parks Canada, 1994b: 119). This definition, as well as the Cultural Resource Management Policy (hereafter abbreviated to CRM Policy) it originates from, will be examined more closely within chapter three when the Policy is applied to illuminate the ways archaeology is used on national historic sites.

Archaeology, an important part of cultural resource management, is often defined as the study of past societies through their material remains (Renfrew and Bahn, 1996: 11). It is a form of research that examines the physical remains of the occupation, development or settlement of land by carefully removing layers of soil and other deposits and recording the inter-relationships of artifacts, soil deposits and archaeological features. At national historic sites across the country, archaeology is being done to learn more about the history of the site and the people who used it. The effectiveness of archaeological work depends on the degree to which links can be made to other research disciplines which may help us understand a site. In the simplest terms, while history provides us with written documents or oral histories about a site, many details regarding social history simply were not written down. Archaeology is an important form of research because it can illuminate aspects of history that were not recorded in historical documentation but that are nonetheless important in learning about the human experience. Most commonly, archaeology occurs after historical research and is used in association with, and to assist, other disciplines in answering specific questions about the 
history, use or development of a site. Unfortunately, archaeology is a destructive activity and archaeological deposits are removed as research occurs. This means that they cannot be re-examined - as historical texts within an archive often can - and that the recording of each deposit is essential. While the public most commonly considers artifacts as being material remains excavated from the ground, some archaeologists also maintain that historical structures and landscapes should also be considered artifacts (Renfrew and Bahn, 1996: 11).

In addition to exploring the development of both archaeology and cultural resource management, this thesis looks at the development of Parks Canada's National Historic Site system as a fundamental part of achieving a full understanding of the role archaeology continues to play on national historic sites and in cultural resource management. Chapter one will examine the historical development of the archaeological discipline as well as the development of the federal Parks Canada Agency, and its use of archaeology on national historic sites prior to the initiation of the Parks Canada CRM Policy. The Historic Sites and Monuments Board of Canada (HSMBC), the organization which advises Parks Canada and the government on the creation of national historic sites, will also be briefly examined. Chapter two will examine the origins and development of CRM and will explore the impact of Parks Canada's adoption of a cultural resource management approach and its use on national historic sites.

According to the Directory of Designations of National Historic Significance in Canada, there are currently 919 national historic sites across Canada's ten provinces and three territories (Parks Canada Agency, 2006). ${ }^{4}$ Of these sites, Parks Canada currently

\footnotetext{
${ }^{4}$ Figures current to December 1, 2006.
} 
owns or operates $155^{5}$ sites with the balance being owned, maintained, operated and managed by many different shareholders (provinces, municipalities, private individuals, businesses or non-profit groups). The remaining 764 sites, because of the diversity of those who own and operate them, and the degree to which they are public or private, all undergo varied forms of cultural resource management and would prove difficult to systematically examine in terms of the ways archaeology has been used in their management (Parks Canada Agency, 2003c). While many externally managed sites, regardless of ownership, have experienced some degree of archaeological investigation in association with CRM and could be used as case studies for this thesis, two "best practice" examples have been chosen from within the province of Ontario: Fort Henry NHS and Fort Wellington NHS. Both of these sites are owned and operated by Parks Canada and therefore share a managerial framework.

Finally, it is hoped that by focusing on national historic sites that are administered by the Parks Canada Agency, a valuable snapshot of the ways archaeology can be used as a form of cultural resource management can be achieved. Parks Canada attempts to ensure that the national historic sites they administer, being part of the system of national historic site types and themes represented, provide a model for the field because of its commitment to quality, its long experience, because it is the most important centre of conservation expertise in the country, and because, ultimately, Parks Canada has the resources "to do things right" (Stovel, 2007). Data will be gathered from archaeological site reports and ancillary reports (including summaries, progress reports, and conference papers).

\section{${ }^{5}$ Ibid.}


The geographical focus of this thesis is on the province of Ontario. This is due solely to the location of the academic institution within which the author has completed her studies and for which this thesis was written. While this research could have taken place in any province of the country, Ontario has the additional benefit of a long history of archaeological practice and the largest number of national historic sites across the country (Parks Canada Agency, 2006).

The third and final chapter of this thesis will explore archaeology as it is used today as a tool of cultural resource management by Parks Canada as well as its relevance in the application of the principles of CRM. This chapter will begin by examining local and international charters and conservation guideline documents from Canada and the world to expose various approaches to the use of conservation principles concerning archaeological investigation and the management of cultural resources revealed. Then the chapter will look more directly at the principles of cultural resource management as applied by Parks Canada. Finally the chapter will review two case studies, Fort Henry NHS and Fort Wellington NHS, to gain a sense of the place of archaeology in the application of the Parks Canada CRM Policy to the management of national historic sites. Archaeological research at each of the Forts will be examined to illuminate the ways archaeology has contributed to these national historic sites in terms of the principles of cultural resource management and their impact on issues such as site interpretation, knowledge of methods of historic construction and the better management of site visitation.

The thesis will consider these benefits to archaeology in detail: archaeology can provide new information that can be used for site interpretation and a better 
comprehension of the social life and social aspects of a site. Additionally, archaeology can be used to illuminate methods of historic construction and determine the original physical location of previously unrecorded resources furthering appropriate physical interpretation of a site and finally, the discipline can be used to manage tourism on national historic sites by providing information to protect historic and archaeological resources during the construction and alteration of visitor and site maintenance infrastructure.

It is believed that while archaeology has been (and continues to be) used on many national historic sites in conjunction with heritage conservation, the general public often does not understand the importance of the discipline and its contribution to today's society. Without public understanding and support, it is difficult to ensure budgets adequate to support important archaeological activity on national historic sites.

By examining the historical development of archaeology and cultural resource management and their use by Parks Canada on national historic sites within the province of Ontario and providing case studies which demonstrate the integral role archaeology plays in their social interpretation, physical interpretation and maintenance and management, this thesis will demonstrate that archaeology is a valuable research tool in cultural resource management. 


\section{Chapter One}

This chapter will examine the historical development of the archaeological discipline as well as the development of the Parks Canada Agency and its use of archaeology on national historic sites in the context of cultural resource management. In this thesis, it is important to understand how archaeology was used by Parks Canada prior to their adoption of a cultural resource management approach. The archaeological discipline has evolved greatly since the development of CRM and it is important to fully understand its foundations within the province of Ontario and within the professional environment which ultimately created the need for cultural resource management.

The goal of this chapter is to examine the historical development of archaeology in the post-war period between 1945 and 1980, a period which saw vast changes in both archaeological theory and public support of the discipline. The development of the Parks Canada Agency and its system of national historic sites, many of which required archaeological investigation, will also be examined paying particular attention to the conditions which favoured the adoption of a cultural resource management approach. Although the history of archaeology within this thesis is focused on the discipline's historical development and use within the province of Ontario, whenever possible, comparisons to the history of archaeology across the country and North America have been made. As this chapter will also reveal, using Parks Canada as a prime example, archaeology has been an essential building block as well as a catalyst in the development of CRM throughout North America. 
Archaeology in Ontario: 1945 - 1985

In many ways, to study the history of archaeology in Ontario is to study the history of archaeology in Canada. While "archaeologically, Ontario constitutes the richest province in the Dominion...", Ontario also has the longest history of the development of both archaeological practice and theory in Canada (Noble, 1972:15).

During the period between 1945 and 1985, archaeology within Ontario was growing in both an academic and professional capacity. This period served to strengthen and establish the discipline, as well as to create political interest the in the protection of archaeological resources for the first time within the province. While progress must have seemed slow at the time, over forty years archaeology within the province advanced from a minor activity in the universities and throughout the urbanizing province, to becoming a pervasive force for which several important protective legislation measures were developed.

Although the period between 1945 and 1985 will be the primary focus of this historical overview, it is important to at least briefly explore the origins of the archaeological discipline in Ontario to provide a context in which to place later developments.

The use of archaeology in Ontario dates back to the 1830s. Both in the New and Old World, early archaeological research generally occurred as an attempt to learn more about the evolution of humans. Specifically, within North America, early archaeologists were often interested in tracing the origins of Aboriginal people and examined above ground burial mounds in an attempt to do so. In Canada, these investigations were 
carried out as early as 1835 by members of the Geological Survey of Canada (Noble, 1972: 3).

In 1851 the Canadian Institute was established in Toronto. The Institute had lofty goals and hoped to "[advance] ... the Physical Sciences, the Arts and Manufactures..." and "[acquire]...branches of Knowledge... connected with the Professions of Surveying, Engineering and Architecture" (Killan, 1980: 3). Although it took several decades to become established, the Institute would ultimately act as the "foundation for a scientific archaeological tradition in Ontario" (Killan, 1980: 3). Early standards of excavation, theoretical procedures and archaeological reports were published by researchers in the Institute's own Canadian Journal which encouraged the discussion of archaeological issues for the first time in Canada (Killan, 1980: 10).

In 1926, the Department of Anthropology was established at the University of Toronto. This program was the first of its kind in Canada and promised to educate scholars in both anthropology and archaeology. Ontario benefited more than other provinces from the training and subsequent employment of many of these early Canadian-trained anthropologists and archaeologists. Other universities throughout Canada were slow to offer archaeology or anthropology programs and it was not until much later, in the 1950 s and 1960 s, that they began to establish similar programs (Kelley and Williamson, 1996: 7-8).

Unfortunately, the program at the University of Toronto could not immediately provide graduate level and advanced training in anthropology or archaeology and scholars wanting further training generally had to leave the country. A lack of educational opportunities for scholars within Ontario and Canada ultimately meant that 
during the early post-war period, there were very few Canadian-born and Canadiantrained archaeologists in Ontario (Kelley and Williamson, 1996: 8).

The first university programs established to train aspiring archaeologists, like that at the University of Toronto, were created within anthropology departments and focused strongly on evolution and prehistory (Noble, 1972: 1). For many years, given this anthropological orientation, archaeology in Ontario was "prehistoric archaeology" and this is only too well reflected in the histories of the earliest establishment of archaeology within Ontario. ${ }^{6}$

The post-war period brought "massive and dramatic changes" to the ways archaeology was practised throughout Ontario and Canada (Ferris, 1998). At the time, as W. E. Taylor admits, "the period... presented ... [both] a broad potential and beggar's resources" (Taylor, 1976: 151). Although there were few archaeologists in Canada, most of them were teaching and doing research in Ontario and many are still well known in the field today (Wright, 1985: 425).

While J.V. Wright suggests that the period following the Second World War was one of “...major expansion...", Taylor has a conflicting opinion (Wright, 1985: 425). Taylor describes a lack of professionally trained archaeologists, a struggling prehistoric archaeology stream and a virtually non-existent historic sites archaeological discipline. He suggests that archaeology was struggling academically well into the early 1940s but that changes were occurring throughout Ontario that would impact how archaeology was practised in Ontario and beyond. At the time, these changes were difficult to recognize

\footnotetext{
${ }^{6} N B$ : Terms that may not be familiar to all audiences have been defined within the glossary on $p p$. viii- $\mathrm{x}$. The first instance of these terms being used has been italicized and underlined within the thesis.
} 
and it is only now, in retrospect, that they have become more apparent (Taylor, 1976: 152).

In the period leading up to and including the Second World War, archaeologists had become more conscious of interpreting archaeological artifacts based on their function. This classificatory-descriptive period was seen both in Canada and in the United States and persisted until the conclusion of the war.

Following the war, an economic boom in both Canada and the United States provided increased funding to universities and allowed for the hiring of more professors specializing in anthropology and archaeology. The first generation of Canadian archaeologists carrying out graduate training abroad returned to the province and filled the newly available positions teaching a new generation of archaeologists (Trigger, 1978: 81). Unfortunately, the slow start of the discipline and limited access to graduate education meant that archaeological method and theory in Ontario and throughout Canada had always been and would continue to be several steps behind that of the American discipline. Kelley and Williamson, in their 1996 article examining the position of archaeology within the discipline of anthropology, suggest that even into the 1960s Canadian archaeologists "were busy doing the work that Americans had accomplished in the 1930s and 1940s" (Kelley and Williamson, 1996: 10).

While some archaeologists believe that Canadian archaeological policies and legislation have been too dependent on American examples (Taylor, 1976: 154), others believe that "Canadian archaeologists have often sought to maintain a certain intellectual and social distance from their colleagues in the United States" drawing upon methods and theories from British and European intellectual traditions as well as American (Kelley 
and Williamson, 1996: 10). Regardless, Canadians have tended to be relatively conservative in terms of archaeological theory, generally "[holding]... a middle-of-theroad position, or ...[staying] behind the leading edge" (Kelley and Williamson, 1996: 9). Rather than practicing experimental archaeological theories and procedures, deemed costly in terms of both time and money, Canadian archaeologists generally have preferred to use more established practices and adopt new methods only once they have been fully established by international archaeologists with more progressive and experimental inclinations.

While some might argue that this archaeological conservatism is related to Canadian nature in general, it is more likely that this stemmed from the lack of resources that consistently plagued the discipline. It is difficult to be progressive or to test cutting edge theories when a tight financial situation imposes a constant struggle to make ends meet while finishing the minimum research required and the maximum allowed by funding. Unfortunately, this has always been a reality of archaeology in Ontario as the discipline has never received a great deal of funding.

David Boyle, historically recognized as "Canada's first full-time professional archaeologist" received a salary approximately one tenth of those archaeologists employed by the American Smithsonian (Kelley and Williamson, 1996: 6). To put this into perspective, during the same period, while the American Pennsylvania State Museum annual budget for archaeology was around $\$ 50,000$, the Ontario Provincial Museum had a miniscule budget of only $\$ 2,600$. Kelley and Williamson attribute the limited support for early archaeology to a weak economy and to recognition that there 
were only a limited number of spectacular archaeological resources known to attract the interests of wealthy patrons (Kelley and Williamson, 1996: 7).

In general, archaeology has received very limited support from both provincial and federal governments throughout the country (Trigger, 1978: 82). As MacDonald suggests, unfortunately, "the personnel and resources [provided for archaeology within the province] look rather sparse in relation to the size of the country..." especially when one considers the “...quantity of our archaeological remains” (MacDonald, 1976: 76-77). While limited funding often discourages the development of new procedures, it can also act as a catalyst for the creation of new, more streamlined methodologies. As will be demonstrated within chapter two, at Parks Canada, the development of a new way of managing archaeological resources stemmed from difficulties encountered on national historic sites in terms of long term planning and decision making (Lee, 2007). The new way of managing archaeological resources, embodied in cultural resource management, would ultimately allow resources to be better managed and protected while conserving limited funds.

Archaeology as an academic discipline has received various levels of academic and government support since it was first established within the province. Although in its earliest conceptions, archaeology was always considered to be an important part of anthropology, the current use of archaeology as a tool to supplement historical documentation is relatively recent. It was not until archaeology was used to enhance the prehistoric record that historians began to take notice of the many alternative types of information archaeology could provide. As a direct result of archaeology's limited influence throughout academia, the process of developing regional histories based on 
prehistoric archaeological material and truly understanding the prehistoric development of the province has been slow. Kelley and Williamson suggest that for Ontario, the first major history of Ontario's prehistoric development was not published until $1966^{7}$ (Kelly and Williamson, 1996: 9). This means that although Ontario has benefited from having the "longest tradition of sustained [archaeological] research in Canada", the actual adoption of archaeology for extensive use in supplementing existing prehistoric and historic knowledge bases was quite limited until well into the $1960 \mathrm{~s}$. It is telling that it was not until the late 1970 s that prehistoric archaeologist Bruce Trigger was finally able to conclusively argue that within Ontario, "[archaeological]...findings [were] contributing not only to more accurate historical and ethnographic knowledge but also to a more satisfactory view of native peoples and their place in Canadian history and society" (Trigger, 1979: 205).

The 1970s saw a substantial increase in the practice of salvage archaeology ${ }^{8}$ and archaeologists began to seriously contemplate new ideologies relating to archaeological resource management. Archaeological resource management was seen as an allencompassing approach to salvage archaeology that re-examined the traditional view that the destruction of archaeological resources was "normal" As W.J. Byrne suggested in 1976, a "gradual shift from a ... passive acceptance of the inevitability of the destruction of archaeological resources... to an almost militant insistence upon the rights of archaeology..." was evident (Byrne, 1976: 140). For the first time, society was

\footnotetext{
${ }^{7}$ J.V. Wright's The Ontario Iroquoian Tradition.

${ }^{8}$ Salvage archaeology has been defined as "the swift excavation and collection of artifacts at sites in immediate danger of destruction, usually by major land modification or construction projects...

Archaeologists record and recover as much of the site as they can in the brief period before it is destroyed" (Archaeological Institute of America, 2006). In Ontario, during the 1970s there was a period of swift urbanization which saw archaeological sites being threatened more than ever before. In response to the threat, archaeologists began practicing salvage archaeology to quickly recover as much information as possible from threatened sites (Ferris, 1998).
} 
beginning to recognize archaeological finds as resources in the same way natural assets such as fish, timber or minerals were recognized as resources. Provincial legislation began to reflect the ideal that no resource, including archaeological deposits, should be squandered or unjustifiably destroyed (Turnbull, 1976: 121). Additionally, the general public began to expect those responsible for the destruction of archaeological resources to provide adequate funding to properly investigate the resource prior to its destruction (Byrne, 1976: 138). These new expectations across Ontario and the country acted as a catalyst for provincial archaeology programs and new legislation that was created in many provinces including Ontario (Kelley and Williamson, 1996: 8).

In the years leading up to the 1970 s, archaeologists had been spending more and more time performing archaeological rescue excavations as rapid expansion and urbanization occurred throughout Ontario. In 1974 the Ontario Heritage Act (OHA), among other issues, addressed the need to protect archaeological and other heritage resources (Williamson, 2000: 159). Among other regulations, the Act established mandatory licensing laws for all archaeologists carrying out archaeological fieldwork within the province (Ferris, 1998).

In 1975, Ontario's Environmental Assessment Act was passed to deal with growing environmental concerns within the province. This included legislation that required archaeological investigation be carried out on private or Crown land prior to any action that would be destructive to an archaeological resource (Ferris, 1998).

Although by the 1980 s the archaeologists hired in the post-war era had begun retiring, in general, the government failed to hire archaeologists to fill the vacant positions due to "a general effort to reduce federal and provincial deficits" (Kelley and 
Williamson, 1996 :8). Although the federal government continued to downsize, the recent adoption of protective archaeological legislation throughout the province meant that new types of positions were available including those concerned with archaeological resource identification and management (Kelley and Williamson, 1996: 8).

In 1982, a new piece of legislation, the Planning Act, identified the “...conservation of features of significant architectural, cultural, historical, archaeological or scientific interest..." as a provincial concern that must be addressed during future development and land use planning. The Planning Act attempted to ensure that private sector developers within Ontario would consider the impact of their development on heritage resources in advance of all development (Ferris, 1998).

These new pieces of legislation had a dramatic impact on the way archaeology was being performed within Ontario: for the first time archaeologists were compelled to not only research prehistoric archaeological sites, but also to examine “....any building, structure, machine, device or thing made by Man..." (Ferris, 1998). The legislation provided much needed incentives for archaeologists to examine historical sites and other kinds of sites that had not previously been examined through traditional, research based archaeology (Williamson, 2000: 158). While the archaeological investigation of these sites was often quite limited, the legislation had acted to solidify historical archaeology's role in both academic and traditional archaeological practices (Ferris, 1998).

The increase in archaeological investigation required by the new legislation throughout the province had a drastic impact on archaeology in Ontario after 1982. Archaeologists began practising as consultants throughout the province - being paid to offer their expertise in either locating or excavating archaeological resources that were 
going to be damaged through new development. For the first time, archaeologists were providing services which would encourage not only the use of archaeological sites for research but which would strengthen the management of these sites as non-renewable resources. In a 1998 article by archaeologist Neal Ferris, it was suggested that during this period archaeological consulting had become a major industry, and had resulted in the location and recording of between 500 and 700 new archaeological sites within the province. Ferris also stated that the industry was employing more full time and seasonal employees every year (Ferris, 1998).

Drastic changes to archaeology in the early 1980s ushered in a period of archaeological change in Ontario, one which is still unfolding and yielding many surprises. Current archaeological trends have shifted towards the holistic approach of CRM which, as chapter two will demonstrate, has the primary purpose of protecting the resource and provides clear guidelines to ensure that this is done utilizing a transparent and discernable process. 


\section{Parks Canada and the National Historic Site System}

The Parks Canada Agency and the Historic Sites and Monuments Board of Canada (HSMBC) are pivotal in the development and maintenance of the complete National Historic Sites system. An understanding of the development of both the National Historic Sites system and the agency that administers it is fundamental in achieving a full appreciation of the role archaeology plays on national historic sites and ultimately in cultural resource management.

This portion of chapter one will provide historical background regarding the development of the Parks Canada Agency and its system of national historic sites. The role archaeology has played on these sites will be examined in an attempt to illuminate the way archaeology was being utilized prior to the development of the Parks Canada CRM Policy in the early 1990s. Cultural Resource Management, as a broad management tool for archaeological, historical and cultural resources, and its eventual adoption within the Parks Canada CRM Policy, changed the way archaeology was being performed on national historic sites across the province and country. As this chapter will reveal, archaeology was an essential building block and a catalyst in the development of CRM throughout North America.

As far back as the mid-1880s, the federal government was laying a broad foundation for natural and cultural heritage preservation; the first dedication of land as a "public amenity" was declared by the Queen's Privy Council for Canada in 1885 and included ten square miles at Banff Station, Alberta (Parks Canada Agency, 1999: 2). The land formed the core of what would later become the first Canadian National Park (Nichol, 1969: 22). While this land was originally preserved for purposes relating to the 
improved health of Canadians, or what the Queen's Privy Council referred to as sanitation, by 1887 , ideology regarding the purpose of national parks had shifted and an Act establishing a new park, the Rocky Mountain Park of Canada, cited the main reason for the land preservation as recreation (Nichol, 1969: 22).

It was several years before the National Park system had developed sufficiently enough to require a substantial management system and it was not until 1911 that the Dominion Forest Reserves and Parks Act assigned a Commissioner of Dominion Parks to oversee their administration. At the same time, the Act allowed for the establishment of Dominion Parks within already established forest reserves across the country. These parks were deemed important for the "...benefit, advantage and enjoyment of the people of Canada" (Nichol, 1969: 22).

Although financial constraints were always a burden on the development and maintenance of the parks, tourism acted both to encourage federal support and provide income even during this early period (Nichol, 1969: 23). In essence, the parks were being utilized as a natural resource which not only encouraged their use for recreation, but also acted to encourage industries relating to this exploitation (Brown, 1969: 47).

The dual use of both national historic sites and national parks as tourist destinations and as sites of natural and historic preservation has required Parks Canada to balance efforts between preserving the sites and encouraging their active use. Unfortunately, as national parks and national historic sites are developed, increased pressure is often placed upon the very resources that have been deemed worth protecting. In 1968, at a conference organized to discuss Canadian National Parks, John S. Marsh observed that "[land] use problems [were] growing in the national parks [along with 
the]... recognition of the need to "manage" parks and wilderness" (Marsh, 1969: 123). Marsh questioned the historical tendency to identify national parks as areas of recreation, many forms of which drastically alter the environment in which they take place and detract from their wildness - the exact characteristic that was originally deemed worth protecting (Marsh, 1969: 123). Marsh also pointed out that with the desire for increased recreation within national park areas came the need for facilities required to make such recreation more comfortable for those utilizing it, including provision of visitor centers, restrooms, hotels and transportation routes. Parks Canada constantly runs the risk of over-development of their sites and of a stronger focus on the use of the national parks, rather than the protection of sensitive ecosystems or their wildness (Marsh, 1969: 126127).

In an early attempt to curb the use of national parks as areas heavily dependent on exploitative forms of recreation, the National Parks Act was established in 1930 to formally recognize the national parks system and provide loose guidelines for its management. This Act solidified preservation philosophies within Canadian legislation in an attempt to encourage site preservation and discourage the development of sites solely for the exploitation of the tourist industry (Nichol, 1969:23). Following the introduction of the National Parks Act, the National Parks program thrived with the creation of fifteen more parks between 1911 and 1930. The pace slowed significantly in the following years however, with only five new parks being established before $1965 .^{9}$

\footnotetext{
${ }^{9}$ The parks established during this period were the Cape Breton Highlands, Nova Scotia (1936), the Prince Edward Island National Park, Prince Edward Island (1937), Fundy National Park, New Brunswick (1948), Nova National Park, Newfoundland (1957) and Kejimkujik National Park, Nova Scotia (1965) (Nichol, 1969: 24).
} 
Today there are fifty-four national parks across the country, each acting as part of a larger system of preservation within Canada (Parks Canada Agency, 2005c). ${ }^{10}$

According to Christopher James Taylor, author of Negotiating the Past: the Making of Canada's National Historic Parks and Sites, ${ }^{11}$ the Lundy's Lane Battlefield, located in Niagara Falls, Ontario, is one of the earliest national historical commemorations in Canada. Commemorated in 1895, Taylor believes that this site represented a turning point in the recognition of historically significant sites because the Lundy's Lane Battlefield was deemed to be significant not only at local and provincial levels, but to the entire country. Essentially, as Taylor suggests, the Lundy's Lane Battlefield was seen as representative of an "...event [that] affected the future development and outlook of the nation..." (Taylor, 1990: 5-6).

The period after the turn of the century and before the First World War brought several new developments in heritage commemoration. At this time, both the federal and provincial governments began to recognize a need to preserve and commemorate historic sites. Around 1910, the federal Department of the Interior launched the Historic Sites and Monuments Program which was created in an attempt to recognize and eventually mark sites of national significance (Killan, 1976: 165).

In Ontario, independent historical societies also began to recognize the importance of the province's most significant sites and quickly drew connections between their role in both provincial and Canadian development. As reflected in the commemoration of Lundy's Lane Battlefield, the historic sites most commonly

\footnotetext{
${ }^{10}$ For a full list of National Parks, please refer to Appendix I, pp. 114-115.

11 This text, based on his $1986 \mathrm{PhD}$ thesis for Carleton University's School of Canadian Studies, National Historic Parks and Sites, 1880-1951: The Biography of a Federal Cultural Program, is the major history of the national park and historic site system in Canada.
} 
commemorated within Ontario during this period were often associated with loyalist traditions or the War of 1812 . These commemorations ultimately began a long tradition of celebrating both the Canadian elite and Canada's military (Killan, 1976: 127).

The idea of the creation of an organization to facilitate the commemoration of nationally significant sites originally stemmed from the model of the Quebec Battlefield Commission (QBC). This Commission had been established to commemorate the Plains of Abraham site prior to the celebration of the three hundredth anniversary of the founding of Quebec by Champlain in 1608 (Thomas, 1990: 31). The federal government, hoping to emulate the success of the QBC created the HSMBC to develop a similar program for all of Canada.

As has been shown, the commemoration of nationally important historic sites began in the late nineteenth century. However, it was not until 1919 with the creation of the Historic Sites and Monuments Board of Canada (HSMBC), that the federal government began to recognize historic sites of national importance (Taylor, 1990: 6). During the earliest period of commemoration, patriotic and historical societies were predominantly responsible for the historical commemoration of sites deemed significant. These groups focused on the protection of historically important sites because ideologically, commemoration seemed the honourable thing to do (Taylor, 1990: 7). Local and national groups, including the Royal Society of Canada, became concerned that the rapid development of urban areas would eventually destroy Canada's historic sites as well as their associated information and ties to Canadian history. These organizations often promoted an interest in the past for what they referred to as "scientific reasons" (Taylor, 1990: 8). 
By 1919 , five heritage professionals from across the country had been appointed to the Board, in addition to J.B Harkin acting as the Commissioner of Dominion Parks and F.H Williamson as Board secretary (Historic Sites and Monuments Board of Canada, 1979: 2). ${ }^{12}$ The newly created group wasted no time and by 1921 , forty-six sites had been recommended for commemoration (Historic Sites and Monuments Board, 1979: 2).

In 1922, under the leadership of Prime Minister Mackenzie King, the government began to re-examine the role the HSMBC should play in heritage commemoration. While some Board members hoped for the creation of regional boards to better facilitate national commemoration, the government remained committed to the idea of a national body to co-ordinate the efforts involved in site identification, acquisition and development (Thomas, 1990: 31-32). Ultimately, under King's government, the HSMBC became one of the only federal programs that attempted to link the appreciation of Canadian history with the promotion of a national civic culture (Marsters, 2004: 9).

The first national historic site was commemorated in 1922 at the place in which Canada was ceded by France to Great Britain in 1763 - Port Dover, Ontario. The Board established a method of commemoration at Port Dover, a bronze plaque placed on a fieldstone in the location of significance, a practice it maintains to this day ${ }^{13}$ (Historic Sites and Monuments Board of Canada, 2003).

During the early years of the program, the HSMBC struggled to designate a diverse range of sites, both in terms of the provinces they represented and the types of history being commemorated. Board members also struggled to work within a program

\footnotetext{
${ }^{12}$ Other Board members included E.A. Cruikshank (Ottawa, Ontario), J.H. Coyne (St. Thomas, Ontario), Benjamin Sulte (Ottawa, Ontario), W.O. Raymond (Saint John, New Brunswick) and W.C. Milner (Halifax, Nova Scotia) (Historic Sites and Monuments Board of Canada, 1979: 2).

${ }^{13}$ Today bronze plaques continue to be used, but are more commonly freestanding rather than placed on a stone cairn.
} 
that required each board member to be both impartial and objective. In order to ensure that sites were commemorated on the basis of their broader significance rather than on the emotional attachment of any given board member, objectivity was necessary. Unfortunately, with powerful members from both Ontario and Quebec dominating HSMBC meetings, these two provinces had many more sites designated than the rest of the country (Marsters, 2004: 9). By the end of 1929, the Board had marked 172 sites of national significance with fifty-eight located in Ontario, thirty-eight in Quebec, thirty-six in the Maritimes and forty in the West (Marsters, 2004: 47-48).

Following the 1951 Royal Commission on National Development in the Arts, Letters and Sciences, the Historic Sites and Monuments Act established the HSMBC by statute, enlarged the board ${ }^{14}$ and increased its resources for both commemoration and conservation. This was an attempt to rectify the imbalances within the program and allow for more preservation to take place on nationally significant sites (Historic Sites and Monuments Board of Canada, 2003). It was following this piece of legislation that the Board was assigned to commemorate nationally historic persons and nationally historic events (Taylor, 1990: 3).

An amendment to the Act in 1955 allowed the HSMBC, for the first time, to recommend the national designation of buildings based on either their age or architectural design. This amendment significantly broadened the scope of the program, allowing it to include streetscapes, districts and gardens, as well as both urban and rural landscapes (Historic Sites and Monuments Board of Canada, 2003).

\footnotetext{
${ }^{14}$ The Board now has seventeen members, with each province being represented by one member. Ontario and Quebec are the exception to this rule, and each have two representatives on the Board. Additionally, representatives from the National Archives, Parks Canada and the National Museum Association also hold positions on the Board (Historic Sites and Monuments Board of Canada, 1979: 3).
} 
Today, the function of the HSMBC remains largely the same. Although the position of the HSMBC within the federal government has shifted slightly ${ }^{15}$, the HSMBC continues to act as a statutory advisory body, currently to the Minister of the Environment and the Government of Canada. The HSMBC still provides recommendations regarding the commemoration of nationally significant people, places and events within Canadian history, roughly $80 \%$ of which are nominated by the public (Historic Sites and Monuments Board of Canada, 2004).

Ellen Lee, Director of Archaeological Services at Parks Canada, suggests that archaeology at Parks Canada during this period was on the cusp of a major change. In general, archaeology at Parks Canada's national historic sites up to the early 1980s was development oriented and focused on revealing existing information pertaining to the designation of the NHS. As well, as national historic sites were being designated and developed for the public, and visitor services, access roads and public facilities were being developed to allow for public access and interpretation, destruction of archaeological resources was often necessary, and salvage strategies were necessary. Furthermore, because most national historic sites were being managed based on one overarching historical or cultural theme, archaeologists working in this period excavated within restricted realms, often giving little time or attention to the archaeological details of deposits unrelated to the designated theme (Lee, 2007).

\footnotetext{
${ }^{15}$ Before December 13, 2003, the Parks Canada Agency and the National Historic Site program were under the direction of the Minister of Canadian Heritage; After December 13, 2003, as the result of an order of council prior to the adoption of Bill C-7, (an act to amend the Department of Canadian Heritage Act and the Parks Canada Agency Act and to make related amendments to other Acts), governmental reorganization placed both the Parks Canada Agency and the National Historic Sites program under the direction of Minister of the Environment (House of Commons, 2005).
} 
One of the major problems of archaeology during this period at Parks Canada was the lack of an explicit and consistent for utilizing archaeological research in the interpretation and management of national historic sites. While archaeologists were always involved at a given NHS, they often worked independently of both planning teams and historians. In general, no one involved in the development of sites during this period was keeping broad, all-encompassing records which could provide adequate descriptions regarding who made key interpretation decisions on a site, or why. Additionally, Parks Canada was not yet consciously considering or recording the value of cultural resources and as a result, personal opinions and preferences regarding the development, interpretation and management of a site could easily be given free reign (Lee, 2007).

In the mid-1980s, Lee began to notice an interesting shift in the use of archaeology at Parks Canada. At first, this change was most evident in archaeology's use at national parks which, from an environmental perspective, were always managed holistically with the intent to protect the resource for future generations. In response to provincial heritage and environmental legislation encouraging the investigation, protection and management of all historical and cultural resources, Parks Canada national park wardens and archaeologists began working together to locate, describe and analyze cultural resources within national parks. Archaeologists working within national parks were not restricted to specific time periods as archaeologists at national historic sites often were. Rather, they began to compile the earliest management plans for cultural resources, investigating resources as they were found to determine their boundaries, potential and historical or cultural associations (Lee, 2007). 
By 1986, the extensive consultation process leading to the development of the Parks Canada Cultural Resource Management Policy had begun. It was hoped that the process could make archaeology more transparent and could provide a more scientific and structured way of managing national historic sites across the country.

This chapter has examined the historical development of both the archaeological discipline and the Parks Canada Agency to overview the use of archaeology on national historic sites managed by the Parks Canada Agency in the context of cultural resource management. The archaeological discipline has evolved greatly since the development of CRM and it is important to fully understand its foundations within the province of Ontario and within the professional environment which ultimately created the need for the approach of cultural resource management. These changes, as will be demonstrated, strongly influenced the practice of archaeology on both national historic sites and archaeological sites across the country.

The goal of this chapter has been to examine the historical development of archaeology with a focus on the post-war period which saw vast changes in both archaeological theory and public support of the discipline. The development of the Parks Canada Agency and its system of national historic sites was also examined to illuminate the conditions which favoured the adoption of a cultural resource management approach. As this chapter has revealed archaeology has been both an essential building block and a catalyst in the development of CRM throughout North America. 


\section{Chapter Two}

Cultural resource management is an important tool for all of those involved in the protection and maintenance of "historic sites". The goal of this chapter is to study the origins of cultural resource management and to examine its connections to the discipline of archaeology. The impact that cultural resource management and the Parks Canada CRM Policy have had on the practice of archaeology and on the way the Parks Canada Agency manages sites of cultural heritage value is not ambiguous. Indeed, CRM has enabled Parks Canada to develop and hone a set of clearly defined principles and guidelines which can be used to objectify the determination of the value of cultural resources and provides a consistent, transparent framework to integrate consideration of that value in decision-making.

By studying the foundations of cultural resource management and the eventual adoption of the practice as a management policy at Parks Canada, this chapter will demonstrate the importance of the CRM Policy as it has been applied to both archaeological practice and to the management of Parks Canada managed national historic sites across the province. The historical background provided within this chapter will set the context for the final chapter in which two national historic sites will be examined to demonstrate the integral role archaeology plays in cultural resource management. 


\section{The Foundations of Cultural Resource Management}

At its inception, cultural resource management was utilized most often within the field of archaeology for the management and protection of archaeological sites. It was only later that it evolved into the interdisciplinary management tool that it is today. This evolution can best be understood by examining source material written and published throughout its development. Although legislation and practice in the United States had the strongest impact on the development and evolution of CRM, many of the changes that occurred there influenced the way archaeology and historic preservation are practised throughout Canada and across the world.

In 1974, in Denver, Colorado, the first major conference was held to discuss the emerging approach of CRM. At the time, the approach was suggested as being an important key to drastically improving "...the preservation of archaeological sites as a

[finite] resource..." (Lipe and Lindsay, 1974: vi). This conference brought together professionals with diverse academic backgrounds including archaeologists, managers, engineers and environmentalists, from a wide range of private and public institutions and industries (Lipe and Lindsay, 1974: i). All of the professionals involved had a strong desire to discuss the importance of a new way of looking after archaeological resources.

That same year was also a major turning point in American archaeology. Archaeology had evolved quickly from being practised almost exclusively academically, with what were considered pure research motives, to being practised more frequently on a contract or salvage basis. This change directly reflected the prosperity of a time which encouraged land development throughout the United States at an unprecedented rate. Contract salvage archaeology quickly became the norm in American archaeology and 
those practising it, as well as those practising more traditional forms of archaeology, became concerned for the future of the discipline.

Fortunately, along with increased development came an increased awareness of the need for the protection of archaeological materials, now recognized as non-renewable resources. Archaeologists successfully lobbied the federal government for increased protection of archaeological sites in an attempt to show that it was important to "... actively begin to take steps to insure that [the] resource base [would last] as long as possible" (Lipe, 1974: 214). This ideology, loosely termed conservation archaeology, was a precursor to the development of CRM.

Both approaches ultimately originated from the creation of archaeological and heritage legislation beginning in the late 1960s, including the National Historic Preservation Act (NHPA) ${ }^{16}$, the National Environmental Policy Act (NEPA) ${ }^{17}$, Executive Order (11593), the Archaeological and Historical Preservation Act ${ }^{18}$ and the Archaeological Resources Protection Act ${ }^{19}$ (Mathers, Darvill and Little, 2005b: 3).

Each piece of legislation played an important role in the eventual development of the approach of CRM: the NHPA authorized the federal government (via the Secretary of the Interior) to create a national register with which to record physical aspects of cultural and historical importance. The acceptance of a resource on the national register validated the historical or cultural significance of the resource. Additionally, through Section 106 of the Act, the NHPA offered registered properties protection from destruction by requiring approval of the Advisory Council for any action that might be physically

\footnotetext{
161966.

171969.

181974.

191979.
} 
disruptive or damaging. Executive Order 11593 was included within the NHPAs Procedures for the Protection of Historic and Cultural Properties in 1971. It further enforced the NHPA and required the establishment of procedures to deal with federal and private historic or cultural resources (Scovill, 1974: 7). The NEPA became an important aspect of conservation archaeology and CRM. The Act required the inclusion of cultural, as well as natural resources in all environmental impact statements (Stine, 1992: $10)$

Finally, the Archaeological and Historical Preservation Act (also referred to as the Moss-Bennett Act) has been considered quite important for its role in "...[strengthening] ...existing cultural resource program[s] by reaffirming and expanding the federal role in CRM" and providing the funds necessary to do so (Stine, 1992: 12). For the first time, federal agencies were authorized to spend up to one percent of a given project's budget on activities such as surveying, recovery, protection, and preservation of any archaeological and historical resources that would be adversely affected by the project (Stine, 1992: 12). Although perhaps not recognized as such at the time, all of these activities would later be recognized as important to the CRM process. As a result the Archaeological and Historical Preservation Act provided a necessary boost to the developing approach of CRM and allowed salvage archaeologists to strategically position themselves to dominate many of the positions that were opening as a result of this and other pieces of new legislation (Karamanski, 1980: 73).

The profusion of legislation in the 1970s concluded with the Archaeological Resources Protection $A c t^{20}$ which provided more control over who was doing archaeological excavation by requiring permits to conduct investigations (King, 2002:

201979. 
147). This Act was largely in response to an increase in the looting of archaeological sites, but also served to prohibit the sale and transportation of archaeological remains within the United States and internationally (McManamon, 2000: 44).

References to conservation archaeology within literature and academic journals began to appear in the mid-1970s and were undeniably a reaction to the archaeological requirements imposed by these new pieces of legislation. However, it was not until the late 1970s that archaeologists began to recognise that a significant change was occurring. In 1977, Edwards S. Rutch and Kim M. Peters announced in the journal, Historical Archaeology, that "...archaeology [was]... in a period of change from the exploitation of cultural resources to their conservation and utilization" (Rutch and Peters, 1977: 34).

Philip Goldring, a cultural resource historian suggests that "...the practices that are now covered by the term CRM date back much earlier than the 1960s" (Goldring, 2006). This lack of discussion about CRM prior to the mid-1970s may be attributed to variances that must have existed within terminology at the time. Goldring proposes that "the term means different things to different practitioners... [and] practitioners who used the term in the 1960 s meant something quite different from what [is often meant] today" (Goldring, 2006). This is clear in the early sources dealing with conservation archaeology and CRM, as it has proved to be extremely difficult to trace the use of specific terms given inconsistency of use. The comparison of two sources published in 1974 and heavily influenced by one particular scholar reveals use of opposite terms when referring to virtually the same thing. William D. Lipe wrote a pivotal article describing "A Conservation Model for American Archaeology" which is consistently referenced by many scholars who later write about CRM, yet Lipe also played a major editorial role in 
the development of the already mentioned Proceedings of the 1974 Cultural Resource Management Conference, which essentially discussed developments in archaeological conservation camouflaged under the new name cultural resource management.

In his Conservation Model, Lipe defined conservation archaeology as having a responsibility for conserving the whole archaeological resource base. According to Lipe, to practise conservation archaeology it was necessary to "... actively begin to take steps to ensure..." the maintenance of the archaeological resource base (Lipe, 1974: 214). Lipe concluded that excavation was "...only part of a larger resource management responsibility" which also included the identification, protection and management of archaeological sites (Lipe, 1974: 214-215).

Later, at the CRM Conference in Denver, Colorado, Lipe failed to provide a definition for cultural resource management, but seemed to use the term interchangeably with similar terms suggestive of conservation archaeology. It is interesting to note that although the new term had been adopted, the proceedings of this conference dealt almost entirely with the already established archaeological view of CRM, which remained reliant almost entirely on archaeologists.

These two sources, so alike in purpose may be the best available evidence regarding the transformation of conservation archaeology into CRM. While it seems that, at least preliminarily, this change was in name rather than practice, it was only a matter of time before the new CRM approach moved beyond archaeology.

It is therefore clear that although there were few, if any, direct references to CRM prior to 1974, the ideas surrounding CRM were being discussed under other names. During the early 1970s, well respected academic archaeology journals including Historical 
Archaeology, American Antiquity, the American Journal of Archaeology and the Journal of Field Archaeology were regularly publishing memos, articles and reports detailing the increasing importance of archaeological conservation / cultural resource management in the field. These articles make it possible to chart the initial development of both conservation archaeology and CRM in the field of archaeology.

In 1976, archaeologist Thomas F. King discussed the fast-paced development of a new form of archaeology, which he termed cultural resource management and which he compared to other narrower fields including public archaeology and conservation archaeology. He recognized that those participating in CRM were not just archaeologists, but also included "...historians, and architects, planners, government officials and members of public agencies..." (King, 1976: 236).

By 1977, Michael B. Schiffer and John H. House were emphasizing the importance of the explosion of CRM, which they recognized as being "... one of the most important and rapidly developing fields of archaeological endeavour" (Schiffer and House, 1977: 52).

In 1978, the journal American Antiquity created a new section entitled "Cultural Resource Management" which focused on “...articles that [were] relevant to this rapidly expanding concern" (Sabloff, 1978: 551). Jeremy A. Sabloff explained that the new section was meant to "...[recognize] the impact public archaeology [had] had on the field..." (Sabloff, 1978: 551).

While articles examining the explosion of CRM in archaeology and assessing its contributions or shortcomings were generally limited to the period in which the approach was first defined, articles and books on the topic are still being published (Mathers, 
Darvill and Little, 2005a). Archaeologists and heritage professionals are still attempting to determine the best way to identify, evaluate, protect and manage both archaeological sites and other heritage resources. The broadening of the field of CRM acted to encourage future discussions on what the approach consisted of.

Unfortunately, when it comes to examining the transition of CRM into a broader approach encompassing other disciplines, there is no one set of sources available. CRM, as has previously been mentioned, was adopted and adapted within many fields including architecture, history, engineering and planning. Because each of these fields is so unique, it has proved impossible to find a source, or a group of sources, that would allow for primary document analysis as had been possible with archaeological journals, and information regarding the shift from a focus on archaeological conservation to a broader, more interdisciplinary approach is much more scattered and less well defined.

The journal, Public Historian, proved to be the single most helpful source in providing both candid and scholarly viewpoints about the evolving discipline, and the historians' role (or lack of role) within it. Again, there was a gap between the early stages of CRM as an interdisciplinary field and the discussion of it in academic journals, with the first articles being published in the early 1980s. These articles reflect the struggles historians were facing within the new field and their desire to be included despite the "bias toward archaeology..." that many felt existed (Karamanski, 1980: 75). While many felt that "...historic preservation [could play] a large role in cultural resource management..." they also recognized that "the historical profession [had] by and large displayed a shameful degree of indifference to..." the field (Karamanski, 1980: 71-72). 
While historians James Dykman and Lawrence B. De Graff believed that "the differences between an archaeologist's and a historian's approach to cultural resource management ultimately [revealed] different presumptions of the nature of the past and its relationship to the present" (Dykman and De Graff, 1987: 155), another historian, Elizabeth A. Lyon, was quick to point out that "history [is able] to provide the context for the identification, evaluation, interpretation, and use of our historic and prehistoric resources..." (Lyon, 1982: 72-73). It seems that although historians recognized the value of their participation in CRM, history remained on the fringes of CRM for many years.

Today, history plays a major role in both archaeology and CRM by providing important historical contexts for planning archaeological excavations as well as for appropriately managing national historic sites.

Although legislation indicates that the late 1960 s and 1970 s were a turning point during which heritage resources began to be recognized and protected, systems of evaluating heritage worth have always been considered problematic. Bureaucrats have often questioned heritage professionals' ability to objectively determine the significance of a cultural resource. Heritage professionals are inescapably influenced by contemporary value systems which may not be applicable five, ten, or fifty years down the road. While CRM does not offer means to ensure the absolute objectivity of heritage evaluation, it does offer a set of clearly defined principles for ensuring commitment to basing protection on as objective an understanding as possible of the value of a resource (Parks Canada, 1994b: 119). 


\section{Cultural Resource Management and Parks Canada}

CRM continues to be most commonly practised within the federal agency Parks Canada. While CRM is practised in varying degrees by other bodies across the country, Parks Canada has consistently been the leader in the establishment of CRM policy and practice.

As chapter one described, at Parks Canada in the mid-1980s an extensive consultation process had begun in order to develop a new management approach which could be used on national historic sites by managers, historians, archaeologists and planning teams. ${ }^{21}$ The Policy, adopted in 1994, was based on discussions in archaeological and heritage communities focused on the management of historic and cultural resources. It attempted to rectify the problems resource managers were having balancing concern for protecting and using cultural resources in the context of long term planning and in bringing more transparency to the decision making process (Lee, 2007).

Specifically, social trends and evolving archaeological theories encouraged resource managers to view their resources as assets to be protected rather than commodities to be exploited and began to recognize that current decisions impacting a NHS would continue to have an impact in the future. Cultural resource management was a serious attempt to make the management of resources a process which could be both flexible, based on a specific site's needs, and consistent (Lee, 2007). The Policy provided resource managers with the single purpose of protecting national historic sites and provided a framework within which to do so.

\footnotetext{
${ }^{21}$ To reduce redundancy, these people will be cohesively referred to as resource managers in the context of this thesis.
} 
Gordon Bennett, former Director of Policy at the National Historic Sites Directorate at Parks Canada and a key figure in the initial development of the CRM Policy, has suggested that the development of CRM at Parks Canada utilized the term cultural resource management as had been established in archaeology, but ultimately "...broadened its meaning well beyond its [traditional definition] in archaeology..." (Bennett, 2006).

Bennett also characterized another key difference between CRM at Parks Canada and CRM within the broader archaeological discipline: while archaeological CRM had often been largely related to salvaging archaeological resources in danger of being destroyed due to development, Parks Canada created a management program modeled after the American National Parks Service CRM policy, which is more focused on the conservation of a range of cultural resources. According to Bennett, Parks Canada's version of CRM "...included everything one could imagine in terms of managing cultural resources...[with CRM being] transformed into an umbrella term and concept..." in the process (Bennett, 2006).

The Parks Canada CRM Policy defines cultural resource management as “...generally accepted practices for the conservation and presentation of cultural resources..." (Parks Canada, 1994b: 119). This policy focuses on five core principles under which all cultural resources are managed. The principles, which will be explored more fully in the final chapter of this thesis, are: "value, public benefit, understanding, respect and integrity". It is assumed the cultural resource manager will consider all of these as goals to be met in any decision impacting a NHS. 
The management tool that Parks Canada uses to ensure these five principles are balanced is a "commemorative integrity statement" (CIS), prepared for each national historic site. A CIS is defined by Parks Canada as "...a statement which describes the health or wholeness of a national historic site" (Parks Canada Agency, 1998: 18). Specifically:

A site possesses commemorative integrity when the resources that represent or symbolize its importance are not impaired or under threat, when the reason for the site's national significance is effectively communicated to the public, and when the sites heritage values are respected by all whose decisions or actions affect the site.

Parks Canada Agency, 1998: 18.

The CIS concept is unique to Parks Canada and Canada as a whole and has proven to be an exceptional tool for managing national historic sites across the country.

Although Parks Canada has been quite successful in implementing their CRM program, the program has ultimately received little recognition from heritage professionals and heritage bodies throughout the world. Goldring believes that this has had much to do with the fact that while Parks Canada had been carrying out the CRMlike protection of resources for some time, the agency was very late to adopt a name which could recognizably characterize their approach throughout the world. Rather, for many years Parks Canada carried out such activities under the vague guise of "research", which few were able to recognize as cutting-edge or progressive (Goldring, 2006).

Unfortunately, according to Gordon Bennett, although "...Parks Canada's CRM Policy is [one of the best policies] around, there is very little written material supporting it" (Bennett, 2006). Bennett also suggests that Canada has “... not been as adept as the Australians, British, or Americans at promoting [its] contributions" (Bennett, 2006). 
The adoption of the CRM Policy at Parks Canada in the mid-1990s allowed for resource managers to more systematically manage the national historic sites for which they were responsible. Extensive training regarding the new Policy was made possible during this period through increased budgets for environmental and resource management, and managers were quick to embrace it (Lee, 2007). Ultimately, CRM became an important tool for all of those involved in the management and protection of heritage sites within Parks Canada. It allowed resource managers to work within a more transparent framework and unified the decision making process while solidifying the need for archaeology on national historic sites (Lee, 2007).

The managers of national historic sites often deal with the allocation of scarce resources in the face of competing claims. In the face of these competing needs for resource allocation, archaeology can offer contributions to CRM which no other discipline can provide.

Archaeology is able to uncover unknown resources and reveal underlying or previous states of objects, resources and sites. While historical documentation can provide accounts of resources as they may have existed, archaeology can supply tangible evidence of resources untainted by the subjectivity of authors and representative of the actual resource, rather than a standardized blueprint. Often as-built structures vary substantially from the intended plan recorded by contemporary engineers and planners. Similarly, archaeology provides a physical record of human activities that took place upon a site. Archaeology is able to provide historians and site interpreters with very specific social information regarding life at the site, which is in general not available from contemporary documentation. Additionally, while archaeology provides 
information which can be utilized as the crux for many interpretive stories, archaeology is in the unique position to provide tangible reminders and links to the stories, in the form of archaeological artifacts.

Finally, while historic documentation is critical to the understanding of many national historic sites, it is not threatened in the manner archaeological deposits so commonly are. Historic documentation can be replicated and stored indefinitely for multiple revisions and continued access by historians. Archaeological sites, however, are constantly under threat due to site development, the effects of weather and accidental damage, and the process of archaeological excavation itself. While the goal of cultural resource management is always to protect the resource, often, protection becomes impossible to ensure. In this situation, it becomes the responsibility of the managers of national historic sites to provide the necessary time and resources for the investigation of archaeological deposits (Parks Canada, 1994b: 105).

By studying the development of cultural resource management within North America and at Parks Canada, this chapter has established both the historical and the theoretical context necessary to examine the relevance of archaeology on Canada's national historic sites. Without a thorough understanding of the changes that occurred in the way national historic sites were managed with the advent of CRM and the establishment of the CRM Policy, it would be impossible to look at the use of cultural resource management both for national historic sites and the ways archaeology is practiced on them. 


\section{Chapter Three}

This chapter will begin by examining the key strategies for protecting cultural resources as presented within international and Canadian charters, standards and guidelines. It will then review the development of the Parks Canada Cultural Resource Management Policy and the five principles on which the Policy is based. Archaeological practice, as experienced at Fort Henry NHS and Fort Wellington NSH, will be explored in conjunction with the five principles to determine how archaeology is used within a CRM framework. This will involve identifying new information that can be used for interpretation of social life on a site, illuminating methods of historic construction and the location of previously unrecorded resources and, finally, allowing for the appropriate maintenance and restoration of the NHS. 


\section{Charters, Standards and Guidelines: Policy Comparison from Around the World}

The use of key principles, codified in the form of charters or other documents is one means by which heritage professionals ensure the continued protection and consideration of cultural resources in the modern day. These charters are usually written by heritage professionals, most often at the initiative of ICOMOS, the International Council on Monuments and Sites. Public sector organizations - national, provincial or territorial - within a country also develop policy documents which provide standards and guidelines for heritage conservation. These documents reflect the theoretical stance taken within the professional charters and make meaningful connections between theory and practice for conservation practitioners concerned with various forms of research and intervention, including the use of archaeology on sites.

A brief comparison of several charters, from various English-speaking heritageconscious countries revealed several similarities, especially in terms of the way archaeology is considered and approached. Charters from Australia, Canada, New Zealand and the United States have provided valuable information regarding the theoretical mindsets behind the management of cultural resources in those countries, and helped place the Parks Canada CRM Policy in an international context.

The ICOMOS Charter for the Protection and Management of the Archaeological Heritage $^{22}$ is an international charter which provides guidelines for the protection of archaeological resources (ICOMOS, 1990). This charter hints at the complexities of

\footnotetext{
${ }^{22}$ Please refer to Appendix III (pp. 120-125) for the ICOMOS Charter for the Protection and Management of the Archaeological Heritage in its entirety.
} 
archaeological research and makes connections to external disciplines often utilized within CRM frameworks:

The protection of [archaeological] heritage cannot be based upon the application of archaeological techniques alone. It requires a wider basis of professional and scientific knowledge and skills. Some elements of the archaeological heritage are components of architectural structures and in such cases must be protected in accordance with the criteria for the protection of such structures ... other elements of the archaeological heritage constitute part of the living traditions of indigenous peoples, and for such sites and monuments the participation of local cultural groups is essential for their protection and preservation.

ICOMOS, 1990.

Additionally, ICOMOS believes that, to be effective, the Charter and ultimately the

"...protection of the archaeological heritage must be based upon effective collaboration between professionals from many disciplines ...[and] ...requires the cooperation of government authorities, academic researchers, private or public enterprise, and the general public" (ICOMOS, 1990).

While international charters exist to articulate universal principles to protect archaeological resources, national charters seek to apply these principles to the national context. Australia, Canada, New Zealand and the United States are examples of a few English speaking countries that protect heritage resources through their own legally binding instruments.

The Australian Burra Charter ${ }^{23}$ focuses on the conservation of places of cultural significance and deals specifically with archaeological sites in article 28 . This article looks at the disturbance of fabric:

Disturbance of significant fabric for study, or to obtain evidence, should be minimised. Study of a place by any

${ }^{23}$ Please see Appendix III (pp. 126-127) for relevant excerpts from the Burra Charter. 
disturbance of the fabric, including archaeological excavation, should only be undertaken to provide data essential for decisions on the conservation of the place, or to obtain important evidence about to be lost or made inaccessible.

ICOMOS Australia, 1999.

This suggests that archaeology should not be done for archaeology's sake, but for a defined purpose. One purpose, as suggested, may be to obtain data that are necessary in the accurate conservation of the place. Article 28 also allows for the investigation of a place (including archaeological investigation) as long as “...it is consistent with the policy for the place..." and stipulates that the investigation should be an attempt to answer key research questions which could provide significant information about the site that cannot be obtained through other means of research (ICOMOS Australia, 1999).

The Australian Department of the Environment also follows the international ICOMOS Charter for the Protection and Management of the Archaeological Heritage and several regions of Australia have their own standards and guidelines for archaeological practice. The National Parks and Wildlife Service (NPWS) Standards for Archaeological Practice in Aboriginal Heritage Management place heavy significance upon the need for research plans to accompany any archaeological project including what the NPWS terms "management archaeology" - clearly the regional dialect for cultural resource management (New South Wales National Parks and Wildlife Service, 1997).

New Zealand prides itself on being unique in the ways that its people choose to perceive and conserve their cultural heritage. As such, ICOMOS New Zealand has created its own Charter for the Conservation of Places of Cultural Heritage Value (1992) loosely based on the International Charter for the Conservation and Restoration of Monuments and Sites (also referred to as the Venice Charter, 1966). 
The whole Charter can be applied to archaeological resources, but specific mention of these resources is made in section 9 of the general principles which examines invasive investigation:

Invasive investigation of a place can provide knowledge that is not likely to be gained from any other source. Archaeological or structural investigation can be justified where such evidence is about to be lost, or where knowledge may be significantly extended, or where it is necessary to establish the existence of material of cultural heritage value, or where it is necessary for conservation work. The examination should be carried out according to accepted scientific standards. Such investigation should leave the maximum amount of material undisturbed for study by future generations.

ICOMOS New Zealand, 1992.

This stance on archaeological investigation is similar to that seen in the Australian Burra Charter: when necessary, archaeology and CRM can be practiced on a heritage site, but archaeological research, which is both invasive and destructive, should be carried out with minimal intervention.

The New Zealand Department of Conservation has adopted a set of archaeological guidelines written by K.L. Jones, D. Harlow and D.S. Gosling, entitled Caring for Archaeological Sites: New Zealand Guidelines. These Guidelines incorporate the theories provided throughout New Zealand's Charter for the Conservation of Places of Cultural Heritage Value in a practical way which focuses on management issues and conservation techniques for different situations. ${ }^{24} 25$

\footnotetext{
${ }^{24}$ Some examples include how to manage erosion on archaeological sites, how to manage vegetation on archaeological sites and how to manage archaeological sites that are still utilized for specific tasks including farming and forestry (Jones et al., 2002: iii- v).

${ }^{25}$ Please refer to Appendix III ( $p p$. 128-133) for the New Zealand Charter for the Conservation of Places of Cultural Heritage Value in its entirety.
} 
The Preservation Charter for the Historic Towns and Areas of the United States of America is the United States ICOMOS national committee's adaptation of the 1987 ICOMOS Historic Towns Charter (ICOMOS, United States, 1992). This document is more proactive than the other charters studied within this thesis as it anticipates that property owners and residents will be an integral part of the protection of historic areas rather than relegating the use of the Charter simply to heritage professionals.

The Charter is based on four basic objectives which recognize the forces of natural evolution for urban and rural areas, and suggests that a minimal intervention approach for historic structures involves respecting:

1. The historic development patterns of the place, as these have emerged over time.

2. The special relationships between the buildings of the town or district, and its surrounding streetscape and landscape.

3. The physical attributes of the inside and outside of the buildings themselves. These include not only the main facade of a building, but its construction features, proportions, and interior spaces.

4. The major characteristics of an individual building to be preserved include its scale, materials, construction features, size, style, and ornamentation.

ICOMOS, United States, 1992.

The charter also includes eighteen basic principles which it suggests can be applied to create local preservation programs. These principles can be considered loose guidelines for the appropriate preservation of historic towns (ICOMOS, United States, 1992). ${ }^{26}$

\footnotetext{
${ }^{26}$ Please refer to Appendix III (pp. 134-138) for the Preservation Charter for the Historic Towns and Areas of the United States of America in its entirety.
} 
The United States National Parks Service has been a leader in the creation of both policy documents, standards and guidelines for natural and cultural (including archaeological) resources. In a recent management policy document, the NPS states that:

Archeological resources will be managed [in situ], unless the removal of artifacts or physical disturbance is justified by research, consultation, preservation, protection, or interpretive requirements.

National Parks Service, 2006a.

This follows trends which allow for archaeology when it is to protect resources or understood to be part of a CRM research mandate. The NPS also encourages the incorporation of "...information about archeological resources into interpretive, educational, and preservation programs" (National Parks Service, 2006b). Also utilized within the NPS are the Secretary of the Interior's Standards for the Treatment of Historic Properties (1992), and the associated Guidelines for Preserving, Rehabilitating, Restoring and Reconstructing Historic Buildings (1995). These documents were written to assist the public as well as professionals to exercise "...responsible preservation practices..." and provide guidelines within four treatment approaches: preservation, rehabilitation, restoration and reconstruction, with preservation being the most desirable and reconstruction being a last resort (National Parks Service, 1992).

The Appleton Charter was adopted by Canada in 1983 and was largely based on international charters including the International Charter for the Conservation \& Restoration of Monuments \& Sites (Venice, 1964), the Burra Charter (Australia, 1981), and a Canadian charter, the Charter for the Preservation of Quebec's Heritage (also known as the Declaration of Deschambault, 1982). Although archaeology is not specifically mentioned within the Appleton Charter, the Charter subscribes to the ideal of 
minimal intervention and encourages multidisciplinary approaches to protecting and maintaining cultural resources (ICOMOS Canada, 1983). Closely linked to this approach is the perspective that sites of cultural significance are to be considered as fragile artifacts whose protection is based on properly understanding and interpreting the resource as well as ensuring thorough investigation as may be necessary. According to the Appleton Charter, investigation (including archaeology) is required to precede activity at any cultural site (ICOMOS Canada, 1983). ${ }^{27}$

Strongly echoing the Appleton Charter is the Parks Canada Standards and Guidelines for the Conservation of Historic Places in Canada (2003), a policy document meant to be used by federal, provincial, territorial and municipal governments in the management and preservation of cultural, historic and archaeological sites of national significance (Parks Canada Agency, 2003a). This document provides concise recommendations regarding the treatment of archaeological sites stressing the importance of preserving, documenting and maintaining context within archaeological sites. It is in documents such as this one, meant for government officials as well as the general public, that recommended practices embodied in theoretical charters for archaeological and cultural resource management become most clear.

This exposure to international heritage charters and associated policy and guideline documents has provided an opportunity to review the theoretical stance taken by practitioners of archaeology and CRM within the professional charters. This review also helps situate the Parks Canada CRM Policy in the international context for heritage and archaeological legislation.

\footnotetext{
${ }^{27}$ Please refer to Appendix III (pp. 139-143) for the Appleton Charter in its entirety.
} 


\section{The Parks Canada Cultural Resource Management Policy}

Following the theories established within the Appleton Charter and other international charters, the Parks Canada Guiding Principles and Operational Policies (1994) is a comprehensive policy document which details the role of Parks Canada in the protection, interpretation and management of natural, cultural and historic sites across the county. The Policy, as discussed here, consists of three sections: an overview and ten guiding principles ${ }^{28}$, the description of seven policies based on different types of natural, cultural and historic resources $^{29}$ and an outline of the Parks Canada CRM Policy (Parks Canada, 1994a: Table of Contents).

The Parks Canada Agency states that:

[Cultural resources] must [be managed...] jointly with ... natural resources ... and [Parks Canada] must choose the most effective methods of protection and enhancement ... Archaeological resources are included in the family of cultural resources, and the [Cultural Resource Management] Policy [within the Guiding Principles and

\footnotetext{
${ }^{28}$ The ten guiding principles of the Parks Canada Guiding Principles and Operational Policies are as follows:

1.Ecological And Commemorative Integrity

2. Leadership And Stewardship

3. New Protected Heritage Areas

4. Education And Presentation

5. Human - Environment Relationship

6. Research And Science

7. Appropriate Visitor Activities

8. Public Involvement

9. Collaboration And Cooperation

10. Accountability (Parks Canada, 1994a: 11).

${ }^{29}$ The seven types of policies utilized by Parks Canada to protect different types of natural, cultural and historic resources are: the National Parks Policy, the National Marine Conservation Areas Policy, the Canadian Heritage Rivers Policy, the National Historic Sites Policy, the Historic Canals Policy, the Federal Heritage Buildings Policy and the Heritage Railway Stations Policy (Parks Canada, 1994a: 21).
} 
Operational Policies] makes it possible to practise knowledgeable management of these fragile... heritage resources ...

The Parks Canada Agency, 2005a.

The Parks Canada CRM Policy is based on five sets of principles: the principles of value, public benefit, respect, integrity and understanding (Parks Canada, 1994b: 102105). These principles provide a foundation for management practices and, when making decisions regarding the management of a site, resource managers carefully consider how decisions will uphold the principles. To determine archaeology's place within the Parks Canada CRM Policy, these principles should be carefully examined.

The principles of value are based on the historic and cultural associations which have been recognized as nationally significant. Parks Canada recognizes that “...cultural resources rarely occur in isolation ... and often derive their value from being part of a place or site..." (Parks Canada, 1994b: 102. These values are expressed through attributes which may be physical or material, as well as associative or symbolic. Archaeology contributes directly to the articulation of the value of heritage resources by “...[revealing the] underlying or previous physical state of an object, structure or site" (Parks Canada, 1994b: 103). In essence, archaeology is often able to provide a record of the human activities from which a cultural resource derives its historic value (Parks Canada, 1994b: 103).

Archaeology is a part of efforts to define the significant associations noted above and the attributes linked to them. But archaeology can also help identify resources which may have potential value and guide management to courses of caution which may protect these resources from unnecessary development and, as appropriate, may encourage exploration of these potential values. 
The principles of public benefit relate to Parks Canada's obligation to protect cultural resources for the continued enjoyment of the public (Parks Canada, 1994b: 103). While all five principles are equal and are meant to be used together, the importance of public benefit is evident in the Parks Canada Mandate:

On behalf of the people of Canada, we protect and present nationally significant examples of Canada's natural and cultural heritage and foster public understanding, appreciation and enjoyment in ways that ensure their ecological and commemorative integrity for present and future generations

Parks Canada Agency, 2002a.

These principles ensure that cultural resources as administered by Parks Canada are managed through both the protection and presentation of those attributes that have been deemed nationally significant. Archaeology contributes to public benefit by providing information which allows the public to more fully understand and appreciate the resource, and provides tangible reminders of the past, including artifacts and archaeological features, which connect the public more completely with both the resource and its historic and cultural significance (Parks Canada, 1994b: 104).

The principles of respect require Parks Canada to manage cultural resources with respect for their historic character and to ensure that management is based on the qualities which have been recognized as nationally significant. The principles of respect apply to all types of resources, large or small, including "...the use of landscapes and structures, the display [and] use of artifacts and to public activities affecting cultural resources" (Parks Canada, 1994b: 105). Archaeology supports the principles of respect by providing a means to answer questions about the degree to which historic character is being respected - through environmental impact assessment for example. Specifically, this 
means that archaeology can provide information regarding what features of a cultural resource should be considered significant, and thus be protected, compared to other features that have been drastically modified since the period being commemorated. This may be applied specifically to buildings, which archaeological research may reveal as having been modified, or to more general cultural resources such as the landscape surrounding the cultural resource. Often, archaeology is able to reveal information about the evolution of these features and their original and modified states.

The principles of integrity require Parks Canada to present the past accurately, maintaining a careful distinction between the original resource and restored, reproduced or reconstructed resources (Parks Canada, 1994b: 105). Specifically, evidence which can be tied to a resource is preferred over generic information (based on trends or historical assumptions) (Parks Canada, 1994b: 105). The principles of integrity are greatly supported by the ability of archaeology to find site-specific information. While historic documentation often exists regarding general historic trends and basic historic developments, it is archaeological investigation that can provide information regarding the social and physical development of a site and its occupants (Parks Canada, 1994b: 105). Additionally, archaeology is often in a superlative position to provide the information necessary to make distinctions between original fabric and fabric that has been modified or replaced since the site's establishment (Parks Canada, 1994b: 106).

Although Parks Canada considers all five sets of principles equally significant, the principles of understanding are perhaps most strongly tied to archaeology and cultural resource management and provide a strong foundation for each of the other principles. The principles of understanding stress that: 
the care and presentation of cultural resources require[s] the knowledge and understanding of those resources, of the history they represent, and of the most effective means to communicate that history to the public.

Parks Canada, 1994b: 104.

This level of understanding, as required by Parks Canada, would not be possible without the use of specific forms of research including archaeology which, through CRM, provides managers with a better understanding of the resources, and of the history they represent. Specifically, archaeology can provide information that did not previously exist in written form (Parks Canada, 1994b: 104).

These five principles are applied by Parks Canada resource managers to every action or decision that will impact a national historic site. Parks Canada clearly states that the principles are not mutually exclusive and work most effectively when considered as a whole (Parks Canada, 1994b: 102).

When used appropriately the Policy aims to ensure that the historic character of each resource has been identified, recognized, considered and communicated (Parks Canada, 1994b: 106). The Policy expects that the principles will be applied through the range of activities applied at Parks Canada sites including: corporate direction, planning, research, conservation, maintenance, preservation, modification, presentation, interpretation, special programs and events and services and facilities (Parks Canada, 1994b: 108-115). While the activities of CRM act as implementation mechanisms for resource managers, the principles "...provide the means for determining the appropriateness of actions affecting cultural resources..." and thus create a more transparent way of managing cultural resources (Parks Canada, 1994b: 102). 
Archaeology as it is practiced on national historic sites across the country is both complicated and rewarding. Archaeologists must learn to balance many goals and make decisions based on many external factors. These decisions are not self-evident and each must be carefully weighed in association with the principles of the Parks Canada CRM Policy as archaeological investigation proceeds on a site. Otherwise, the archaeologist risks the survival of the meaning and substance of the archaeological resource.

This chapter will now analyze the decision making process that archaeologists must negotiate within the Parks Canada CRM Policy, specifically the types of decisions that have been made to allow for the effective use of archaeology at Fort Henry NHS and Fort Wellington NHS. A brief historical overview of each NHS is provided to supply important background information on the development, historical significance and structural composition of each site. 


\section{Fort Henry Historical Overview ${ }^{30}$}

Point Henry, on the outskirts of Kingston, Ontario, has always been a strategic location for protecting Upper Canada. It is situated on a natural harbour and faces the convergence of the eastern end of Lake Ontario and the beginning of the st. Lawrence River (Parks Canada 1996: 8). Additionally, it is directly across the river from the historic location of the Royal Navy Dockyards and was on the path of an important trading route connecting Kingston to the eastern portion of Upper Canada (Parks of the st. Lawrence, 2004).

The original fort at Point Henry, herein after referred to as Fort Henry, was built during the war of 1812 at which time a blockhouse and a battery of quns were erected on the point. Defence was improved at the Point following an American naval attack in November of 1812 and, by 1815, the outline of a Fort had been established along with several more buildings within (Cary, 2003: 1). By the 1820s, the Fort had been strengthened to include two large stone defensive towers, two soldiers' barracks, an officers' quarters and a powder magazine. Its configuration was quickly labelled as obsolete however, and construction on a new, six sided casemated redoubt had begun by 1832 (Figure 2). The advanced battery was added between 1838 and 1843 and included the construction of a ravelin and two commissariat ranges (Figure 3) (Figure 4) (Cary and Last, 2004:5). ${ }^{32}$

\footnotetext{
${ }^{30} \mathrm{NB}$ : It is believed that these histories are necessary to provide background context to archaeological information, however, they are not technically part of the arguments made throughout chapter three. To indicate their distinctive role within this chapter, the following brief histories have been uniquely formatted.

${ }^{31} N B$ : Terms that may not be familiar to all audiences have been defined within the glossary on $p p$. viii- $\mathrm{x}$. The first instance of these terms have been italicized and underlined within the thesis.

${ }^{32}$ For further historical background on the Fort Henry redoubt and advanced battery please refer to Appendix II, pp. 116-119.
} 
Fort Henry was manned to various degrees between 1812 and 1920, but never saw an active battle. In 1870, the site was given to the Canadian government and garrisoned by a Regiment of Canadian Artillery. During the First world war the Fort was used to house up to five hundred German POWs but was largely abandoned by 1920 (Cary, 2003: 1). As the Fort began to crumble, Great Depression make-work projects funded by both federal and provincial governments provided the money and manpower to rehabilitate it (Figure 5). Between 1936 and 1938, under the direction of Ronald Way, Fort Henry was repaired and, when necessary, reconstructed to represent its state at the time of Canada's confederation (Cary, 2003: 2).

On August 1 1938, Fort Henry was officially opened to the public as an interpretive museum (Figure 6). However, within a year, the Department of National Defence (DND) had reclaimed the property for use again as a POW camp and later as detention barracks (Cary, 2003: 2). DND continued to use the fort until 1958 when public operation of the site was transferred to the st. Lawrence Parks Commission (an agency of the ontario government) and the site was reopened as an interpretive museum (Parks Canada Agency, 1999).

In April of 1999, Parks Canada, DND and the Canadian government announced the transfer of Fort Henry from DND to the ownership of Parks Canada. The property was considered to have historic ties to both the establishment of Upper Canada in the $19^{\text {th }}$ century and Canada's military history (Parks Canada Agency, 1999). Fort Henry, although long recognized as a site with national importance, was not officially named a NHS until 1981. Prior to this, Fort Henry had been on the agenda of the HSMBC on 
eight different occasions, only to be deferred each time. This deferral may have had something to do with the substantial reconstruction that occurred at the Fort. Ronald Way's work at the Fort may have been perceived as detrimental to some aspects of the site that were considered important to its historical integrity (Parks Canada, 1996: 10). Fort Henry received further recognition as part of a NHS in 1992 when a collection of defensive sites in and around Kingston Harbour were recognized for their strategic importance in response to the oregon crisis with the United States between 1845 and 1846. This designation has been called the Kingston Fortifications National Historic Site and includes Fort Henry, Fort Frederick and the Murney, Shoal and Cathcart Martello towers (Parks Canada Agency, 1998: 1).

In 1995, the Fort Henry Intergovernmental Committee was formed to discuss the future of the Fort and take into consideration local concerns regarding the Fort's continued operation and maintenance. This group, including Parks Canada, DND and members of the community worked together to allow for the transfer of the property to Parks Canada and to create a plan for its continued use as a historic site and museum (Parks Canada Agency, 1999). At the time of transfer in 1999, a major restoration plan was also created to address the deterioration that had occurred at the site over the past decades. A $\$ 5$ million endowment fund, established by the federal government, would act as the necessary catalyst for the collaboration of both the federal government and the provincial government to begin the largest historic restoration project currently being undertaken across the country (Parks Canada Agency, 2004c). 


\section{Fort Wellington Historical Overview}

Fort Wellington is a small but historically significant military fortification located on the shore of the st. Lawrence River. The river itself was an important transportation route which, during the unstable beginning of the $19^{\text {th }}$ century, required substantial protection from American forces looking to invade the British colony of Upper Canada (Burns, 1979: 1). In 1810, Major Edward Jessup surveyed and subdivided his own property to create the town of Prescott. Jessup hoped to capitalize on the booming economic development that the city of Kingston was experiencing by creating a forwarding center for many of the goods Kingston was shipping downriver towards Montreal (Burns, 1979: 6-7). While the town itself took several years to develop, by 1812 increased unrest between Britain and the United States, in addition to the significant role of the river in the distribution of supplies and war materials into the rest of Upper Canada, encouraged the construction of a Fort (Burns, 1979: 11).

Built beginning in January 1813, Fort Wellington was considered by military engineers as "the essential point lalong the st. Lawrencel to be first strengthened" not only for its strategic position on the river but also due to its proximity to Ogdensburg, New York, less than one kilometre across the river (Burns, 1979: 18). While at first the Fort at Prescott was to consist only of a blockhouse, by mid-1813 a much more substantial fortification was developing. The blockhouse was to be surrounded by a "...rectangular earthen redoubt complete with [a] glacis, ditch, $\log$ scarp, rampart and earth-enclosed wooden casemates" (Burns, 1979: 18-19) (Figure 7). 
In early 1814 Fort Wellington officially received its name in honour of Field Marshal Arthur Wellesley, the 1st Duke of Wellington, and work progressed under the watch of Lieutenant Frederick de Gaugreben, a King's German Legion engineer and who was, at the same time, also responsible for the construction of Fort Erie, Fort Chippewa and Fort Niagara. By December of 1814 the fortification was largely finished and the Fort was fully operational and occupied. At first, Fort Wellington was heavily occupied by British troops, housing a staggering 940 officers and men that were stationed at Prescott (Burns, 1979: 19). During this period, approximately 82 acres were employed for the military fortification and an associated outpost battery. Other military structures were constructed outside the rampart walls including "...barracks, storehouses, stables, a forge, a wood yard and a lime kiln..." (Flynn, 1967: 24).

The first Fort, although occupied to various degrees until the late 1830s, quickly fell into disrepair (Flynn, 1967: 26). Around 1823, increased pressures from the growing town of Prescott and diminished requirements for local military protection led to the subdivision and eventual sale of most of the 82 acres that had originally been reserved for Fort Wellington. In a document written by the Department of Mines and Resources $^{33}$, the Department stated that by 1949 only $81 / 2$ acres remained associated with the Fort. The balance of land had been sold off and was now held by private citizens (Department of Mines and Resources: 34$) \cdot{ }^{34}$

\footnotetext{
${ }^{33}$ Although this document cannot be attributed to a specific year, the Department of Mines and Resources was created in 1936 and was replaced by the Department of Mines and Technical Surveys by 1949 (Natural Resources Canada, 2006). This change in departmental name places the publication of this document between 1936 and 1949.

${ }^{34}$ Current sources indicate that Fort Wellington occupies 3.318 acres.
} 
The second Fort wellington, constructed on the ruins of the original fort between 1838 and 1839 due to the threat of the Rebellion, incorporated only the outline of the original earthworks in its plan. The new Fortification included a caponnière and altered the gateway to mount a swivel gun (Flynn, 1967: 26) (Figure 8). Although the concept of a blockhouse was kept, a new blockhouse was constructed with a significantly smaller trace than the first Fort blockhouse and an increased height from one story to three (Burns, 1979: 24). The space previously occupied by the larger blockhouse provided ample room for the construction of a new officers quarters, a guardhouse, a latrine and a cookhouse (Flynn, 1967: 26).

The closest the Fort came to active battle was in November of 1838 when a force of 200 Americans invaded Canada under the command of Baron von Schoultz. On their way to attack, the American group became dispersed and eventually retreated to Windmill point to reconvene. While there, the Americans occupied the point and its buildings, using the stone windmill as their stronghold, until the next day when British forces attacked and overcame the U.S forces in the famous Battle of the windmill (Flynn, 1967: 26).

Following the Battle of the Windmill, Fort Wellington was occupied to various degrees, often in association with an increased threat against the British Empire. It was used between 1843 and 1854 to house the Royal Canadian Rifle Regiment (RCRR), a unique unit of the British army that encouraged its men to have both land and families. The military initiative was tied to the belief that men who had ties to the communities they were stationed in would be less likely to abandon their military 
obligations than young, new recruits brought to the New world for military service (McKenna, 1995: 2-3).

Fort Wellington was reoccupied during the Fenian Raids in 1866 by a local battery of garrison artillery and again during both the Red River rebellion of 1870 and the North West Rebellion of 1886 (Department of Mines and Resources: 34). Finally, after 1886 the Fort was abandoned indefinitely and eventually transferred to the Department of National Defence (Flynn, 1967: 27). At the turn of the century DND used the Fort for the training of Militia units until 1923, when it was transferred to the National Parks Branch of the Department of the Interior to be used as a National Historic Park (Flynn, 1976: 5).

Fort Wellington became one of the first national historic sites to be both owned and operated by the National Parks Branch ${ }^{35}$ and was officially designated a national historic site in 1920 (Parks Canada Agency, 2001: 10). The Fort has been refurbished to reflect its second phase of occupation, during the 1840s, when the RCRR were stationed at the Fort (Parks Canada, 2005d: 1). Over the years, the fort has become the primary driver of Prescott's tourist industry with the town promoting itself as the 'Fort Town' (Parks Canada Agency, 2001a: 2). Visitor usage statistics show that during the course of its 1998 season the Fort had almost 17,000 visitors, many of which must have gone to Prescott largely to visit the Fort (Parks Canada Agency, 2001a: 2).

\footnotetext{
${ }^{35}$ The National Parks Branch was the forerunner of Parks Canada (Parks Canada Agency, 2001a: 1).
} 


\section{The Use of Archaeology on National Historic Sites: Two Case Studies from Ontario}

Within the Parks Canada CRM Policy, CRM is practiced with "...an integrated and holistic approach to the management of..." the resource (Parks Canada, 1994b: 101). While the circumstances for management can vary widely, CRM provides distinct goals that will lead to the best possible protection of a cultural resource after taking into account external influences. The Policy addresses all types of resource management, including archaeological resource management and, thus, provides guidelines which allow archaeologists to make appropriate decisions regarding the need to excavate, what to excavate and how to excavate. Archaeology as carried out at two national historic sites within the province of Ontario will be analyzed and three benefits of excavation will be used to demonstrate the role of archaeology on national historic sites. This section will utilize the five principles of the Parks Canada CRM Policy to show how archaeology is used: to discover new information that can be used for site interpretation and a better comprehension of the social use of a site, to illuminate methods of historic construction and the location of previously unrecorded resources, and to allow for appropriate maintenance and restoration.

At Fort Henry, archaeology has been used to assist planners, site managers, engineers, architects and masons with the restoration of the Fort. Archaeology, practiced prior to the disruption of historical and archaeological resources, has provided countless opportunities to learn more about the site and how it has been used in the past. In many ways, archaeology is just beginning to tell the story of Fort Henry, and its strength lies in the discipline's ability to reveal new information which can be used in a variety of ways in the presentation, restoration and management of the Fort. Excavations throughout the 
entrance ramp, the advanced battery and the redoubt at Fort Henry have been important in ensuring that the current restoration of the Fort has been both sympathetic to historic construction methods and practical in terms of ease of maintenance for the coming years (Last, 2006, Personal Communication).

In strong contrast to Fort Henry, Fort Wellington has been using archaeology for the past fifty years and, as such, is able to provide a very different image of the way archaeology is used at national historic sites. As will be shown, archaeology at Fort Wellington has yielded much information regarding the lives of those living in and working at the fortification. This has allowed the curators at Fort Wellington to place archaeology in the forefront of many of its museum displays and they have incorporated archaeology throughout the refurbishment of the historic site.

Fort Henry and Fort Wellington have many similarities in terms of their historical development and their role in defending the St. Lawrence River from American troops. Both Forts were constructed by the British, originally due to the threat of the War of 1812 and later rebuilt during the threat of the Rebellions in the 1830s. However, each fortification was dealt with in different ways by the Canadian government and, as a result, each site has a unique story to tell about the development of the site as a NHS and the use of archaeology to develop a better understanding of the site's past.

Value obviously lies in archaeology's ability to reveal new information about the past. This information can then be used in a variety of ways throughout a national historic site including the presentation, restoration and management of the site. While information on specific archaeological excavations at Fort Wellington is less available than for Fort Henry, evidence of archaeology in the blockhouse and throughout the 
fortifications ancillary structures and features provided ample material which demonstrated the importance of archaeology in discovering valuable new information. This information can be used for site interpretation and to reveal unrecorded information on the social aspects of a site, to determine the original physical location archaeological resources and, of course, to aid in the development of the national historic site.

The Parks Canada CRM Policy and its five principles of value, public benefit, respect, integrity, and understanding are considered in every action or decision that will affect a national historic site, including the archaeological examples included within this thesis (Parks Canada, 1994b: 102). Throughout the remainder of the chapter, the principles will demonstrate how archaeology is utilized on national historic sites to help identify resources of potential value and to direct management regarding the protection of resources.

Each set of principles is crucial to the appropriate management of national historic sites and archaeology offers unique perspectives to each:

- Through archaeology, the principles of value contribute to the articulation of the value of heritage resources. Archaeological research can document the unwritten record and illuminate the social experience of a society from which a cultural resource derives its historic value (Parks Canada, 1994b: 103).

- While the principles of public benefit ensure that cultural resources are managed through both the protection and presentation of those attributes that have been deemed nationally significant, archaeology provides information which allows the public to more fully understand and 
appreciate the resource, including tangible reminders of the past that allow the public to connect more completely with both the resource and its historic and cultural significance (Parks Canada, 1994b: 104).

- The principles of respect are supported by archaeology through the discipline's ability to provide a means to answer questions about the degree to which historic character is being respected.

- The principles of integrity are possibly best supported by the ability of archaeology to find the necessary site-specific information to appropriately represent a national historic site in terms of its historical accuracy.

- Finally, the principle of understanding is strongly tied to continued research, including archaeology, which provides managers with information not previously recorded. 
The Principles Exemplified:

Understanding and Public Benefit:

Discovering New Information for Site Interpretations and a Better Comprehension of the Social Use of a Site.

As has been demonstrated, the use of archaeology directly corresponds with Parks Canada CRM Policy principles of value, public benefit, understanding, respect and integrity (Parks Canada, 1994b: 108-11). While all of the principles are to some extent linked and overlap, archaeology can be demonstrated to respond to the principles of understanding and of public benefit on the two case study sites examined for this thesis: to discover new information that can be used in site interpretation and for a better comprehension of the social use of a site.

At Fort Wellington, archaeological excavations on a $19^{\text {th }}$ century latrine were done prior to its restoration to ensure that archaeological information was not destroyed during restoration activities. These excavations revealed substantial amounts of information that has been used to improve understanding regarding life at the fort for RCRR soldiers and their families. The public program developed for the site contains displays which were developed using artifacts that are known to have been used during this period at the site.

Within the blockhouse, the ground floor and second floor have been refurnished to replicate the way they would have looked in the late 1840 s, during the occupation of the RCRRs. Archaeological artifacts have been incorporated into these displays, including artifacts recovered in the latrine investigation. In a report on fine ceramics, archaeologist Lynne Sussman describes "...[ten] common clay[,]... unglazed earthenware marbles...Four of [which] were undamaged while the rest were broken" 
(Sussman, 1994: 237). At the site, incorporated into a current exhibit, similar marbles can be seen within the communal eating area of the second floor barracks room (Figure 9).

Another example of archaeological artifacts influencing the historical presentation of the site and thus improving understanding for public benefit can be seen in both the barracks room (second story of the blockhouse) and the officers' dining room. The transfer-print dishes used to set the table in both of these areas were chosen based on archaeological information: as detailed by Sussman, the transfer-print ceramics recovered from the latrine deposit made up the largest decorative group of ceramics in that collection. This assemblage included dinnerware, teaware and serving dishes and was comprised of 260 artifacts with forty different patterns (Sussman, 1994: 213). Likewise, the stemware drinking glasses and glass tumblers adorning these dining areas were also chosen based on their resemblance to those types of artifacts recovered in the latrine excavation (Figure 10).

The excavations of the latrine at Fort Wellington were completed in association with a project which stabilized the foundations of the 1838 latrine which has been suggested is the "...only extant wood-framed military privy of its age in Canada" (Rick, 1994: 1). The artifacts that were recovered from these excavations have subsequently been studied extensively for their connections to the RCRR and as part of a rare snapshot of Canadian military history (McKenna, 1995: 6). This research has been crucial in developing a strong understanding of the development of the story of Fort Wellington, as well as the broader history of the Canadian military prior to Confederation. As Parks 
Canada historian Katherine McKenna states in her report on the RCRR at Fort Wellington:

It is fortunate that Fort Wellington National Historic Park provides [such] a unique non-documentary source of evidence on the presence of the RCRs stationed there... The findings [of recent archaeological excavations in the latrine] have been remarkable. An extraordinary quantity and variety of artifacts were unearthed, and analysis has shown a thriving and unexpectedly rich domestic life during the RCRR period.

McKenna, 1995: 6.

Archaeology at Fort Wellington has been invaluable in creating a greater understanding of the life of the men and their families serving in the RCRR and revealing the many discrepancies that existed between official military documentation and real life at the Fort. One example of such a discrepancy paints a drastically different image of life at Fort Wellington than could have ever been imagined: while RCRR regulations stipulated that there should only be twelve wives living within the barracks for everyone hundred men, archaeological evidence suggests that the regiment had more than the usual number of dependent women and children. Records show that in 1850 the garrison had as many as thirty-eight women and eighty-five children drawing rations (McKenna, 1995: 462). Archaeologically, this is expressed in large quantities of eating accoutrements, which suggests that "...a great proportion of the men of the R.C. Rifles [were] married], [and were having] their victuals cooked according to their tastes..." (McKenna, 1995: 8990). While the exact circumstances regarding meal preparation and consumption are not known, the elevated quantities of tableware suggest that meals may have been prepared separately rather than in a more communal manner. Archaeologists were surprised with 
both the vast array of dish types as well as the variety of patterns in the ceramics recovered from within the latrine (McKenna, 1995: 92).

At Fort Henry, archaeology has been taking place over the past five years within an overall strategy for the management of cultural resources. Excavations always precede major intervention of a given component of the site and, according to the principles of understanding, ensure that underground resources are both appropriately documented and protected. Major research-based excavations at Fort Henry included the archaeological excavation of historic drains which occurred in the redoubt in 2003 . Portions of the drains, one of which had been installed around 1832 and an associated line in the $1840 \mathrm{~s}$, were excavated and surveyed to trace both historic and twentiethcentury drainage systems within the redoubt. These excavations were aimed at improving understanding of the drainage of the site and were important to the physical management of the site. The utilitarian nature of the features under investigation however has meant that little has been altered in terms of physical presentation or public programming.

A later archaeological excavation had a mandate focused on attempting to determine how the original parade was surfaced. Such information would allow for the restoration of the parade to be more historically accurate. Many photographs and depictions of the parade surface provide clues to the original surface, yet these sources do not give a clear solution. While a painting from the late 1830 s shows a dusty clay surface, photographs from the $1860 \mathrm{~s}$ show a surface made of gravel and clay. Unfortunately, archaeologists have so far been unable to definitively attribute an archaeological deposit to the 1830 s parade surface. Archaeologists hypothesize that 
either the parade surface may have been clay and stone fill laid over the bedrock and constantly topped up, or, alternatively, the original parade surface has been removed (Cary, 2005: 54).

In the area of the entrance ramp which connects the advanced battery to the redoubt, a portion of 16 inch gauge railway line was found intact during archaeological investigations. This rail line would have been used to move building stones throughout the Fort during its reconstruction between 1936 and 1939. While historians knew that railway lines and carts were used to move materials during the restoration, this artifact is a tangible reminder of the story of the Fort Henry reconstruction, an important chapter in the life of the Fortification (Marion, Date unknown: 2). This type of artifact is important in the overall interpretation of Fort Henry, not only as a national historic site, but in its early use as an interpretive museum. 
The Principles Exemplified: Understanding and Integrity:

Illuminating Methods of Historic Construction and Allowing for the Location of Previously Unrecorded Resources Furthering Appropriate Physical Interpretation of a Site

Archaeology can be used to locate previously unrecorded resources to improve understanding of the physical composition of a site and to strengthen management practices at the site. Much of the information obtained through this type of archaeological investigation is not available from written records and is best obtained through archaeological research. This type of archaeology is often used to assist a myriad of professionals attempting to manage and protect the cultural resource. Engineers, architects, heritage recorders, historians and masons are just a few of the professions that will utilize archaeological information to uphold the integrity of a NHS through more historically-appropriate repair, restoration or maintenance practices.

Archaeological investigations occurred in and around the blockhouse at Fort Wellington as early as the 1960 s. These excavations, although not completed under the CRM Policy, nevertheless often utilized CRM-like principles given their focus on achieving a better understanding of the blockhouse and its historic integrity. In 1965, archaeologist Karalee Coleman excavated within the powder magazine on the ground floor of the blockhouse. Her excavation was done within an early CRM framework to record historical and archaeological information from within the powder magazine floor prior to the floor's restoration to obtain a better understanding of the historic feature and facilitate appropriate respect and integrity during the course of its preservation. Coleman quickly determined that the floor that was being replaced was not actually original as was 
previously believed and attributed all aspects of the floor which existed in 1966 (the floorboards, beams, supports, as well as deposits of charcoal and mortar) to an earlier reconstruction (Coleman, 1966: 82). While the original plan had been to preserve the floors within the blockhouse (believed to be original), when archaeological information revealed that the floors were actually the product of a more recent modification, restoration plans were appropriately modified. In a follow up to Coleman's excavation within the blockhouse, archaeologist E.A. Wylie excavated within the armoury, storeroom and guardroom prior to the replacement of each floor. In various places, evidence of interior wall foundations from the original 1813 blockhouse was recovered and recorded (Wylie, 1966: 211) (Figure 11). The resulting information was important not only for the understanding of the site but also in maintaining the integrity of the depiction of the values of the site, as the investigation revealed the underlying physical state of the site and enabled a more complete understanding of the relationship between the original 1813 blockhouse and the current 1830s blockhouse (Figure 12). ${ }^{36}$

At Fort Henry, archaeology has been used to assist engineers, masons and heritage recorders in the restoration of several areas of the Fort as well as in the creation of plans to manage the future maintenance of the Fort. While in some cases restoration simply involves the repair of damaged portions of the Fort, in other cases restoration work includes the modification of features that were altered in the 1930 s reconstruction and have since been revealed as inaccurate. The ramp, counterscarp walls, commissariat roofs and several portions of the redoubt casemates are all features at Fort Henry that have benefited from archaeological investigation.

\footnotetext{
${ }^{36}$ As can be seen in Figure 12, in 1921 evidence of the original blockhouse was still visible within the grass surrounding the blockhouse. Currently however, no visual clues of the original blockhouse remain.
} 
Archaeological excavations related to the 1830 s construction period of the Fort focused on revealing the original construction methods utilized in the construction of the ramp wall and showed that an original portion of the ramp wall, consisting of between two and eight courses of dressed stone blocks, was significantly wider and thus more appropriately robust than those portions immediately above it (which have been dated to the 1930s reconstruction). The original stone wall was braced against the mined-out limestone which allowed for very little room to shift since the Fort's original construction. More recent repairs, from the 1930 s and onward, were not nearly as carefully completed and as a result had shifted substantially causing the entrance ramp to become structurally unstable (Cary and Last, 2002: 22).

According to historical documentation, the ramp and counterscarp walls were among the first features of Fort Henry to be restored by Ronald Way's masons in the late 1930s (Cary and Last, 2002: 24). Fortunately, not all portions of the original wall were removed during the reconstruction. Instead, a large portion of the 1832 wall base was retained, with the newly reconstructed wall being built on top. Archaeological investigation of the ramp wall has allowed archaeologists to determine which portions of the existing wall are original and which were replaced during Way's restoration. Ultimately, this investigation facilitated improved integrity within the site as aspects of the ramp wall which were original were distinguished from those aspects which were the result of later maintenance. Maintenance on the ramp wall has continued virtually until modern day and each time the wall was altered, restored or rebuilt evidence of the alteration has been preserved within the archaeological record. Evidence of repair episodes has allowed for archaeologists to gain a better understanding of the continued 
maintenance, preservation and modification of the site. The use of what was believed to be Portland cement allowed archaeologists and historians to make connections between what was recorded in historical documents regarding site maintenance and what building supplies were commonly used during the associated period (Cary and Last, 2002: 24). ${ }^{37}$

In December 2003, a six month project was begun to "...rehabilitate the roof of the Advanced Battery casemates at Fort Henry National Historic Site of Canada" (Parks Canada Agency, 2003c). This work included "...repairs to the timber roof structure, [the] removal of the old roof shingles and installation of a new...[metal shingle]... roof" and was the second phase of the Fort's stabilization (Parks Canada Agency, 2003d).

While originally the restoration of the roof was considered necessary to protect the interiors of the commissariat buildings, archaeological information obtained in the fall of 2003 revealed the existing red roofs to be historically inaccurate and the modification became crucial in order to maintain the integrity of what was presented to the public. The modification returned the roofs to their original pattern of unpainted tin plate shingles and allowed for the commissariat buildings to become both historically accurate and compatible with the historic character of the Fortification (Figure 13). The sections of tin plate shingles recovered in the archaeological excavation were still pleated together and joined with wrought iron nails. Faded portions of the shingles suggested that approximately three inches of the shingle remained exposed to the weather and chemical analysis of the metal showed that it had been left unpainted (Cary and Last, 2004: 18). These recovered tin plate shingles were used to determine how to lay the shingles on the

\footnotetext{
${ }^{37}$ Portland cement is a common form of cement that was first used during the middle part of the $19^{\text {th }}$ century. Additionally, Portland cement was mentioned in historical documents dated to the $1850 \mathrm{~s}$ and 1860 s requesting the material for use in repairs to the Fort (Cary and Last, 2002: 24).
} 
commissariat buildings of the advanced battery during their restoration later in 2003 (Parks Canada Agency, 2003d) (Figure 14).

From an interpretive perspective, archaeological excavations have also contributed to a better sense of the physical requirements of the Fort Henry fortification. Fort Henry, mined directly into the bedrock, would have required huge quantities of the natural bedrock to be removed for its construction, an incredibly labour intensive task. Archaeological information supports historical documents which indicate that, to construct the lower portions of the Fort, an additional two metres of limestone needed to be removed (Marion, Date unknown: 2). This evidence also corresponded with prior assumptions that the landscape in and around the Fort was drastically modified by the Royal Engineers during the construction of the Fort and provided a better sense of the development and use of the landscape.

Archaeological information from in and around the redoubt tells an interesting story regarding the natural, and later man-modified, terrain in this portion of Point Henry. While natural limestone bedrock still remains in the redoubt parade and defensive ditch, excavations suggest that between 2.4 metres and 2.6 metres of natural bedrock was removed. Archaeologists were always aware that substantial work had been employed in the construction of the Fort, however, a volumetric idea of how much natural bedrock had been removed allows for a more concrete understanding of the role humans played in the manipulation of the landscape to suit their needs. In addition to removing substantial amounts of bedrock, builders of the redoubt also had to deal with the existence of several structures that remained from the original 1812 fortification and the need for some form 
of drainage as the natural drainage system of the Point had been irrevocably altered during the removal of the bedrock (Cary, 2005: 42-43).

As has been shown, archaeology at Fort Wellington NHS and Fort Henry NHS has allowed for the illumination of methods of historic construction as well as to locate previously unrecorded resources and allow for an expanded knowledge of the physical composition of each site. 
The Principles Exemplified:

Respect and Value:

\section{Enabling Appropriate Maintenance and Restoration}

Archaeology enables the appropriate maintenance and restoration of historic sites and ensures that these activities are carried out with full respect for the historic value of the site, value which archaeology has helped define.

In 2002, work was begun on the repair and conservation of the entrance ramp walls at Fort Henry (Figure 15). The project, which took about three months to complete, was considered high priority. The entrance ramp acts to provide retaining walls for the main entry way to the Fort and thus is required for this portion of the fortification to maintain structural integrity. While some portions of the ramp walls required minimal repair, other portions had degenerated extensively and required substantial reconstruction and modification (Cary and Last, 2002: 5). Engineers and masons worked together to create a rehabilitation plan that ensured the preservation and use of the maximum amount of historic material, much of which dates back to the Fort's construction in the 1830 s (Parks Canada Agency, 2002b). Prior to the stabilization of the entrance ramp Parks Canada archaeologists completed exploratory excavations in an attempt to assist engineers in determining both the state of the walls and the extent to which they would need to be repaired (Cary and Last, 2002: 5).

A visual investigation of the ramp walls revealed that differences existed between the original 1832 ramp wall and the reconstructed 1930s wall: there was a disparity, visible to the naked eye. Between the two periods of construction the wall had buckled inwards where the 1930s reconstructed wall began (Marion, Date unknown: 1) (Figure 16). Although this difference was easily visible from the outside of the wall, engineers 
wondered what kind of differences would become apparent if the wall was viewed from its other side. In their opinion, complete conservation of the entrance ramp walls could not be achieved until the fill was removed from against the interior of the walls and a better sense of its degradation could be obtained. Archaeological excavations in the fall of 2001 removed the fill making up the first glacis and, for the first time, a complete view of the interior of the west ramp wall and counterscarp wall was possible (Marion, Date unknown: 1).

From the exterior, the ramp wall appeared to be uniform and built in only one or two construction episodes. ${ }^{38}$ However, from the interior, the walls showed evidence of at least five different construction and repair episodes beginning in the 1830 s and continuing virtually until the modern day. Archaeologists were surprised to see that much of the existing wall actually dated back to the 1832 construction of the Fort, rather than being part of the 1930 s reconstruction as was originally believed. In addition to this discovery, archaeological investigations revealed that repairs done prior to the 1930 s restoration had, in large part, been preserved and could be studied for further information. Another surprising discovery showed that portions of the 1930 s reconstruction had actually been removed, probably within the last twenty or thirty years, and replaced with modern refurbished masonry. Archaeological evidence revealed modern modifications to the ramp walls which were believed to have been original, and these modifications were recorded and made distinguishable from the original cultural resource (Cary and Last, 2002: 9).

\footnotetext{
${ }^{38}$ The primary construction would have been early on, around 1832, as both the ramp walls and the counterscarp walls were considered integral in the protection of the Fort. The second construction episode was believed to have been in the 1930s during the Ronald Way reconstruction (Cary and Last, 2002: 9).
} 
The result of this series of repairs has meant that the walls' structural integrity has been compromised over the course of the past century (Cary and Last, 2002: 9). During the 2002 conservation of the ramp walls, stones were removed and re-pointed before being returned to their original position. This allowed archaeologists to see inside the ramp wall for the first time and they determined that between two courses of stone (one interior and one exterior) the wall was filled with rubble. This construction information was invaluable to the understanding of the physical development of the fort and utilized in later restorations. Additionally, this information proved useful to later archaeological excavations which could anticipate this construction method and adjust excavation units accordingly (Marion, Date unknown: 2).

A construction sequence of the ramp area was established based on the information recovered during this archaeological excavation. The six phases evident within the ramp area range from before the 1832 construction of Fort Henry all the way to modern day maintenance activities believed to have been performed in the latter half of the $20^{\text {th }}$ century (Cary and Last, 2002: 18).

Archaeology at the Fort between 1996 and 2002 revealed that in some places, evidence of the original War of 1812 Fort still existed despite the fact that construction of the 1832 Fort had occurred directly above. This revelation, allowed archaeologists to extend understanding of the value of the NHS through the discovery of a previously existing structure that was important not only to the original development of the site as a fortification, but also to the development of the second fortification in 1832 (Parks Canada, 1994b: 103). Although excavations confirmed that the topography of the area had been substantially altered in the construction of the second Fort Henry, excavations 
also revealed that, at Point Henry, the Royal Engineers responsible for planning and constructing the Fort were more willing to adapt to the natural landscape than they had been at other British Forts.

In 2003, archaeological investigations were undertaken within the advanced battery to learn more about and attempt to improve upon existing drainage systems in the Fort. Poor drainage and a high moisture in the area has meant that, in addition to water standing on many of the Fort's surfaces for extended periods of time, frozen water has caused jacking within the masonry and many of the wood features within the Fort had become unstable due to deterioration and rot (Cary and Last, 2004: 4) (Figure 17). It was hoped that archaeological research could provide further information on existing drainage, allowing for the development of a plan that, in the future, could improve upon the current infrastructure. At this time, several units were also excavated in and around areas that would be damaged during the installation of new downspouts and lightning protection (Cary and Last, 2004: 10).

This exploration of the existing drainage at the Fort was very informative from both an engineering and resource management perspective (Cary, 2003: 1). First, a fibre optic camera was used to follow known drains in an attempt to determine the state of the existing system and with the hopes of discovering the point of exit for runoff. Next, archaeological units were excavated in five strategic locations around the western and northern walls of the Fort. These units uncovered two historic drain lines including one from the original 1832 Fort and one which was added around 1848. Both drains were brick-lined and capped with large stone slabs and each had been laid into a channel cut into the limestone bedrock. While both the drains had been flushed in the $20^{\text {th }}$ century 
and contained little in terms of contemporary artifacts, the information obtained regarding their construction and location was invaluable to the continued maintenance of the fortification.

Understanding the natural landscape of Point Henry was the purpose of a 2004 excavation which allowed for a better knowledge of how the first Fort Henry was built and would eventually enable archaeologists to make physical links between the original fortification (1812) and the existing fortification (1832). This information significantly impacted the value of the site by recovering portions of the 1820 s Officers' quarters and revealing the underlying state of the 1812 fortification (Cary and Last, 2004: 21).

The officers' quarters, described historically as a substantial masonry building, was depicted on many early maps of the point. Historical documentation also implied that it had been constructed around 1820 and stood until about 1841 when it was torn down to make room for the current advanced battery. It was shown in historical drawings of Point Henry to have been two stories high and would have required robust foundations on which to stand (Cary and Last, 2004: 21) (Figure 18).

The excavation of a unit on the west central section of the parade revealed an early garbage heap with an assortment of domestic items including "...large plate fragments, wine glass stems, wine bottle fragments and high quantities of [domestic] animal bones..." (Cary and Last, 2004: 15). The quantity and quality of the artifacts discovered indicated that the garbage heap had not been used by the poorer soldiers occupying the Fort but rather by those of higher rank, with a greater ability to buy more expensive goods (Cary and Last, 2004: 15). This unit was the first hint of the officers' 
quarters archaeologists had been hoping to find to tie the early Fort Henry into the existing Fort.

Investigation of what was believed to be the Officers' Quarters occurred in the fall of 2003 when a row of large, cut stones were noticed on the surface of a well worn walking trail which encircles the Fort. Excavation of the area revealed a substantial masonry wall with a depth of over 1.8 metres and a thickness over 1.2 metres (Figure 19). On the interior of the building large quantities of plaster fragments were recovered, believed to have crumbled off of the wall. Wood imprints on one face of the plaster indicated that it had been applied to wood lathing rather than directly onto the masonry. The plaster recovered had a variety of colours and, in some cases, it could be seen that one colour had been applied over top of other colours indicating that the plaster had been repainted as many as four different times during the building's occupation (Cary and Last, 2004: 17) (Figure 20). ${ }^{39}$ Armed with new knowledge, archaeologists were able to use existing historical maps to better anticipate the location of original Fort features in the coming excavation seasons.

The exact location of the officers' quarters within the advanced battery parade would be determined in the 2004 field season with the excavation of the south-west corner of the building. Once this corner was revealed, historical maps could be overlaid onto existing maps on both a north/south axis and east/west axis allowing archaeologists to accurately place the original Fort on the modern landscape for the first time. Once the original Fort has been mapped out in relation to the existing Fort, archaeologists had a powerful tool for the future management of the site: not only would archaeologists be

\footnotetext{
${ }^{39}$ Colours ranged from zinc white to yellow ochre and burnt sienna, see Figure 20 (Cary and Last, 2004:
} 18). 
able to begin to identify features recovered in previous and future excavations, but they would also be better able to anticipate the location of features and plan for their appropriate recovery or protection (Cary, 2004: 11).

Also in 2004, a three year project was begun that included the waterproofing of the top surface of the redoubt, and the repair and conservation of the north wall of the lower fort. In addition to completing major repairs, the stabilization involved recording much of the masonry of Fort Henry. Heritage recording allowed for the recording of the Fort's structural instabilities, but also enabled engineers to develop a monitoring program that could be used to recognize and mitigate small changes in the structures (Bell and Ouimet, 2003: 2). The redoubt modification included removing the existing surface and rubber membrane of the redoubt and replacing it with an improved system that would allow for more complete drainage of water from both the terreplein and from within the walls of the casemates beneath the terreplein (Parks Canada Agency, 2004c).

In June 2001 and again in 2002, archaeological excavations were carried out in various locations around the terreplein in an attempt to answer specific research questions for engineers planning the eventual restoration of the redoubt. These excavations "[assessed the] structural conditions beneath the terreplein surface and over the [existing [drainage system]" and were being carried out under a CRM agenda. Ultimately, the excavations were able to provide valuable information to the both Public Works engineers and the federal Heritage Conservation Program (Cary, 2005: 39).

Archaeological excavations revealed a complicated drainage system with multiple entry points for water within the redoubt and several exit points for water far outside the Fort's walls. Catch basins and brick-lined drains are the main components of the system, 
but some water is also diverted from within the Fort by artificial channels in the bedrock (Cary, 2005: 43-44). Later attempts to improve upon Fort Henry's drainage occurred in the early 1900 s and were uncovered archaeologically in the form of two terracotta drains that had been encased in Portland cement and are believed to have been installed around the time of the First World War. While the Portland cement dates these drains to after 1850 , the Canadian engineers were known to have used the material well into the twentieth century. Additionally, plans for the 1930s reconstruction fail to mention updates to the drainage system, but historic maintenance records show that a plumbing firm was paid to do work at the site in 1912 and 1913 and a year later, more money was spent on drainage (Cary, 2005: 56).

Information regarding the 1936-1938 reconstruction has been invaluable for the restoration architects responsible for planning at Fort Henry as well as for ensuring that the principles of respect and value be factored into all future maintenance and development plans. While it is important to keep as much of the original fabric of the redoubt as possible, it can often be difficult to determine what should be retained based on visual clues alone. While, in general, the reconstruction work was sensitive to historic remains on the parade, in a few cases entire walls had to be rebuilt and historic soils were totally removed (Cary, 2005: 57). Through archaeology, the restoration team has gained an improved understanding of the changes made to the redoubt in the late $1930 \mathrm{~s}$.

Fort Henry's function as a public museum has required the installation of modern facilities within the casemates and included the placing of substantial below-surface utilities including water, gas and electrical lines throughout both the parade and ditch of the redoubt (Cary, 2005: 62). There is often little documentation of the original 
installation of these lines but archaeologists record them for future reference when they encounter them in their excavations. Once these disturbances have been recorded by the archaeologists, future archaeological excavations and the installation of utilities can anticipate them and save valuable time and money, as well as maintaining the physical integrity of the site, by avoiding areas that are known to contain archaeological deposits. As well, if a utility corridor is known to exist in an area which requires an updated or additional service line, the existing corridor can be utilized to prevent unnecessary damage to archaeological resources (Figure 21). 


\section{Conclusion}

The appropriate management of national historic sites requires the use of the key principles of the Parks Canada CRM Policy. At Fort Henry, currently undergoing the largest restoration of any national historic site in Canada, these principles impact the planning, archaeological research, conservation and modification of the site every day (Parks Canada Agency, 2004c). At Fort Wellington, a long established Parks Canada site, archaeological research has been integral to the way the site is presented, interpreted and conserved. Past preservation and modification projects also relied heavily on archaeology to ensure that the site maintained the highest standards of historical accuracy and that future management of the site would be based on sound management plans.

The Parks Canada Guiding Principles and Operational Policies and its associated CRM Policy allow for the best possible management of the national historic sites that are owned and operated by Parks Canada. These sites rely on the principles of the CRM Policy to determine the appropriateness of actions affecting all cultural resources (Parks Canada, 1994b: 102). In this context, archaeology can clearly be understood to be a valuable tool of cultural resource management on national historic sites. 


\section{Conclusion}

In Canada, approximately 2.5 million Canadians visit a national historic site every year. This makes visiting Canada's national historic sites one of the most popular tourist activities today (Parks Canada Agency, 2004b: 3). Maintaining the quality of the visitor experience requires special care of the assets in Parks Canada's hands.

The Parks Canada Cultural Resource Management Policy provides for management of these sites according to the principles of value, public benefit, understanding, respect and integrity, applied to any action that may impact a NHS. These principles ensure that our national historic sites are effectively preserved and understood by the tourists who visit them today and in the future (Parks Canada, 1994: 108-115). Through a CRM framework, these principles draw upon the discipline of archaeology. Unfortunately, few outside the academic world understand the integral role archaeology plays in understanding and managing Canada's national historic sites as it is a topic that has rarely been looked at in a Canadian context.

This thesis has attempted to fill this void by providing a comprehensive exploration of the fields of archaeology and cultural resource management as utilized within the management of Canada's national historic sites. This thesis has provided concrete examples of archaeology being used within a CRM framework and has made connections between the current Parks Canada CRM Policy and actual practice.

- Within chapter one, the development of the archaeological discipline as well as of the Parks Canada Agency was explored. This chapter also identified the way archaeology was utilized on national historic sites prior to the introduction of the Parks Canada CRM Policy. 
- Chapter two focused on the development of the field of cultural resource management and explored its implementation at Parks Canada and the impact the Policy had on the way archaeology was being practiced on national historic sites.

- The final chapter of this thesis took a close look at the Parks Canada CRM Policy and applied the Policy to archaeological examinations that have occurred at Fort Wellington National Historic Site and Fort Henry National Historic Site.

As this thesis demonstrates, the appropriate management of national historic sites is based on key CRM principles as described within the Parks Canada CRM Policy. At both Fort Henry National Historic Site and at Fort Wellington National Historic Site, archaeological research and the continued maintenance of cultural resources has been based upon the principles of value, public benefit, understanding, respect and integrity. Each of these principles is directly supported by archaeological research and has been integral to the way the sites are presented, interpreted and conserved, preserved and maintained.

Further research can be carried out on many of the topics discussed within this thesis. Comprehensive histories of the development of archaeology and cultural resource management within Canada or North America do not seem to exist, nor do up-to-date histories of Parks Canada, the Historic Sites and Monuments Board of Canada or the National Historic Site system. Additionally, although archaeology is being used in a similar manner to those methods outlined within this thesis across the country, documentation does not adequately link the results of this archaeology with the tangible 
changes that are often made to sites based on archaeological information. If these connections are not documented, over time it will become more and more difficult to deduce where information came from and how interpretations were made on these sites.

Recent reports on Fort Henry NHS are excellent examples of multidisciplinary effort which reveal the relevance of archaeology from historical, geographical, architectural, management and material culture perspectives. ${ }^{40}$ These reports explain archaeological findings and their interpretation, but also explain the relevance of this information and how it can be used to make decisions regarding the site's future restoration, management and preservation.

This type of documentation is beneficial to archaeologists attempting to secure federal, provincial or municipal funding for archaeological research done within a CRM framework. If the public and different levels of government are able to recognize the valuable role of archaeology in cultural resource management, they will be more likely to provide the financial support necessary to continue both research and appropriate cultural resource management.

Unfortunately, the general public often does not understand the importance of the archaeological discipline and its value in site management. By examining the historical development of archaeology and cultural resource management and their use by Parks Canada on national historic sites within the province of Ontario, and providing case studies which demonstrate the integral role archaeology plays in their social interpretation, physical interpretation, maintenance and management, this thesis has demonstrated that archaeology is a valuable research tool for cultural resource management.

\footnotetext{
${ }^{40}$ See Cary 2003, 2004, 2005, Cary and Last, 2002 and 2004 and Garcia, 2003.
} 
Figure 2: $\quad$ Evolution of the First Fort Henry 1812 to 1832.

Image from Cary, 2005: 5.

\section{$1812-1814$}
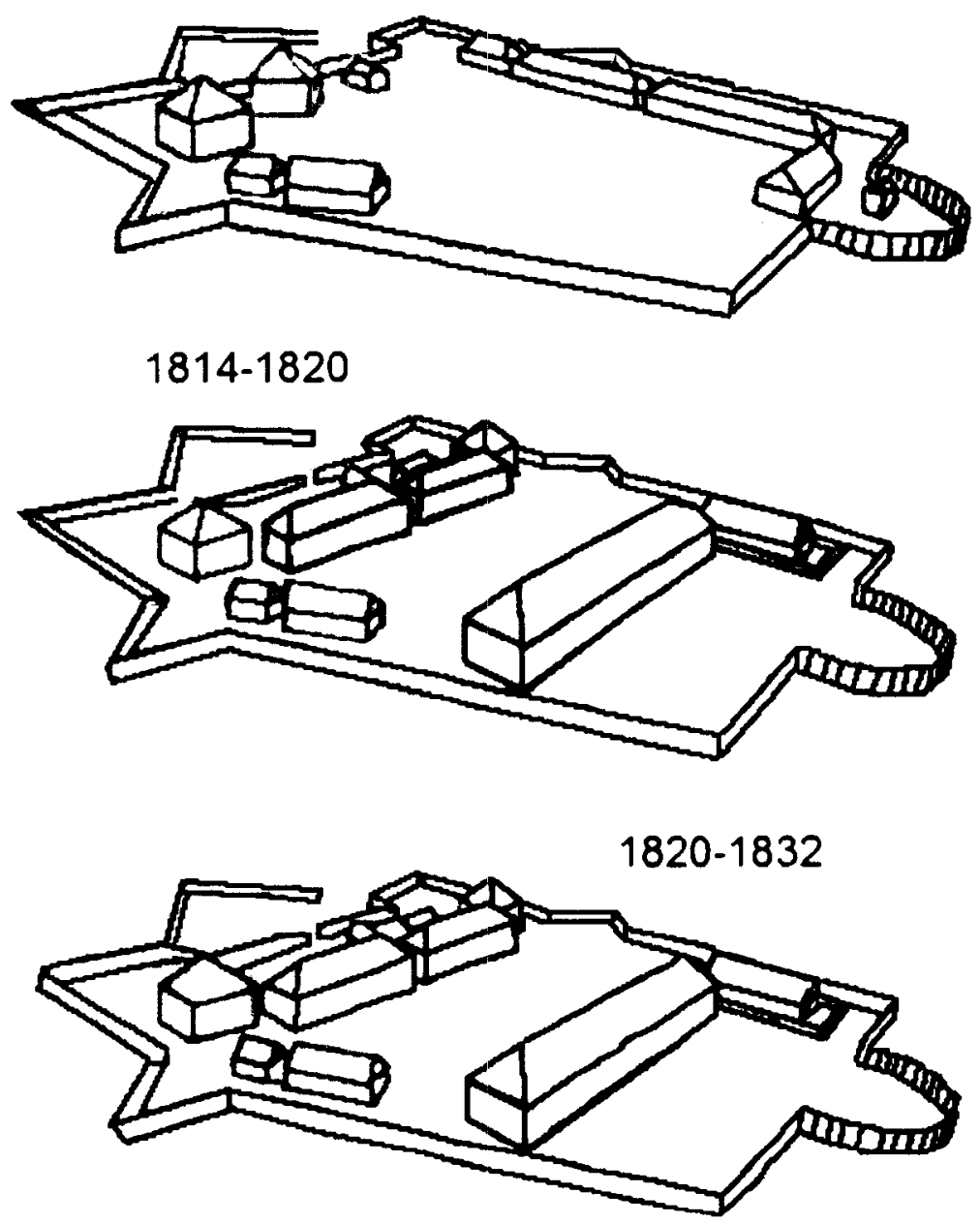
Figure 3: $\quad$ Fort Henry after the addition of the Advanced Battery and Commissariat Ranges circa. 1837.

Image from Cary and Last, 2002: 3. Digitally enhanced by M.E. Novak, 2006.

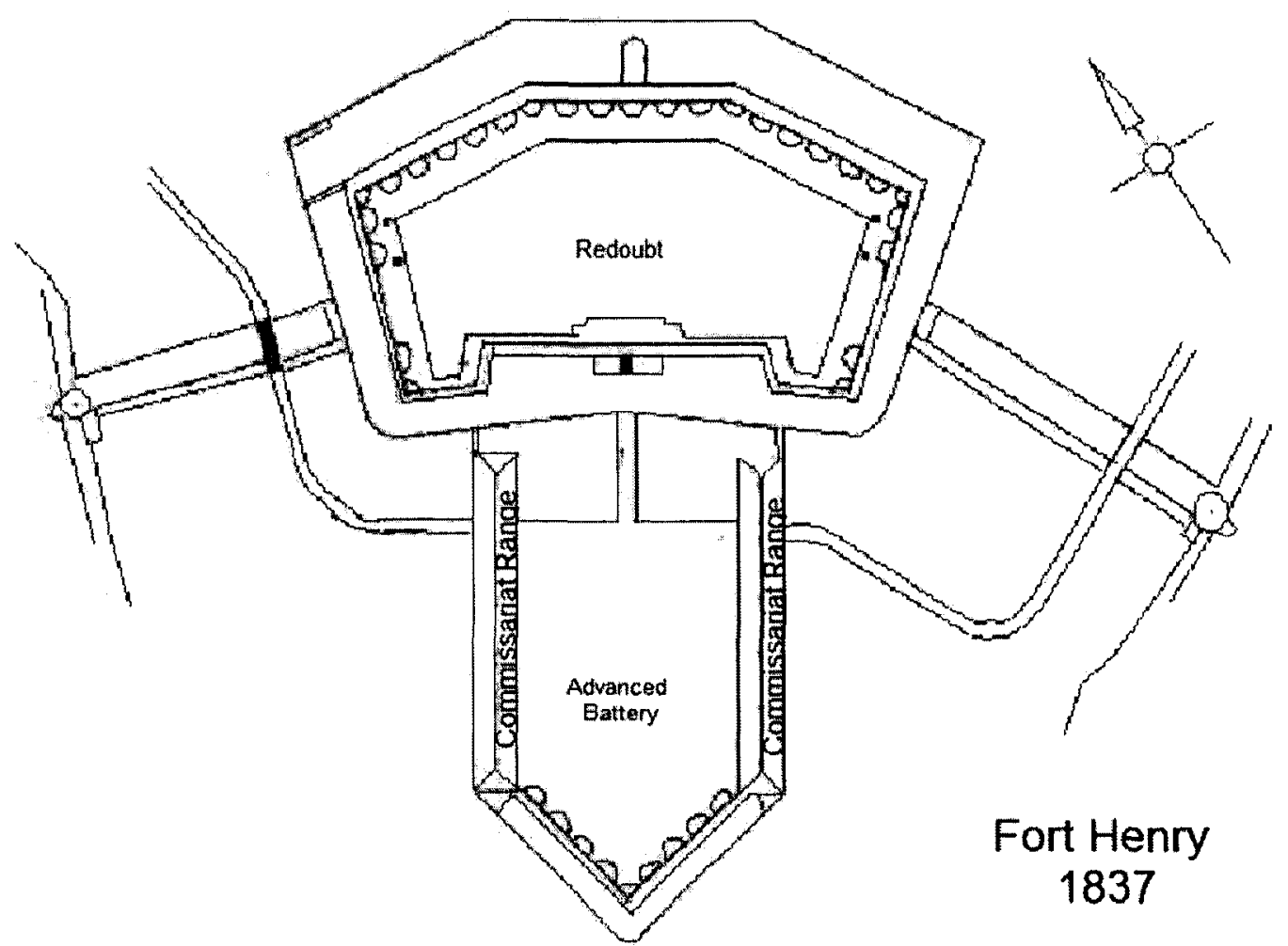


Figure 4: $\quad$ Plan of the Advanced Battery (Upper Fort) at Fort Henry.

Image from Cary and Last, 2002: 3. Digitally enhanced by M.E. Novak, 2006.

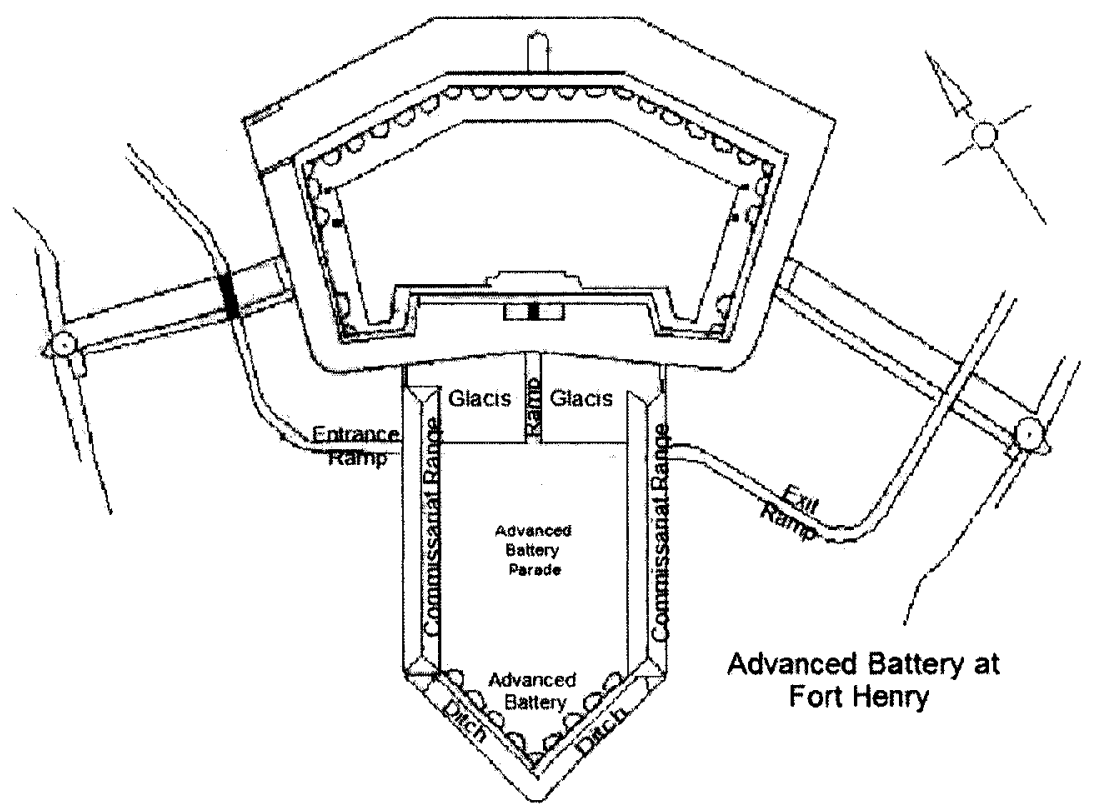

Aerial Photograph of the Advanced Battery at Fort Henry, 2003.

Image from Fort Henry National Historic Site of Canada.

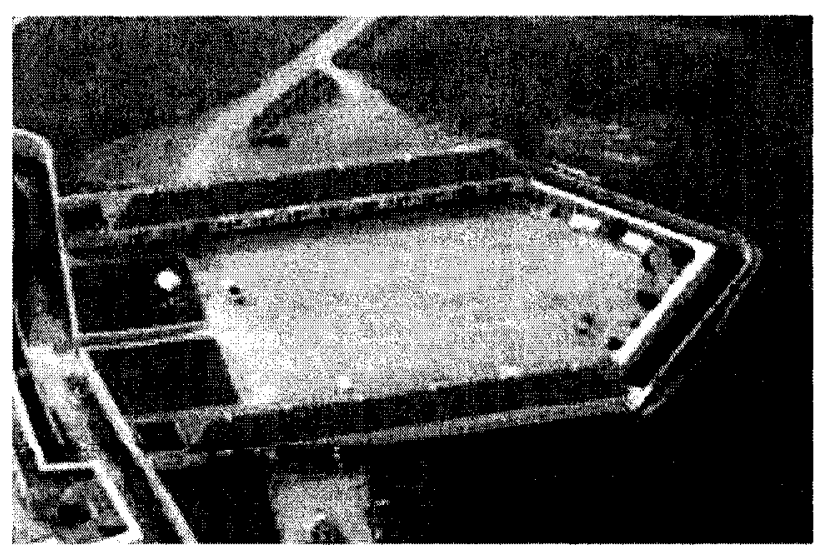


Figure 5: The Redoubt Casemates at Fort Henry during Ronald Way's 1930s reconstruction.

Image from Fort Henry National Historic Site of Canada.

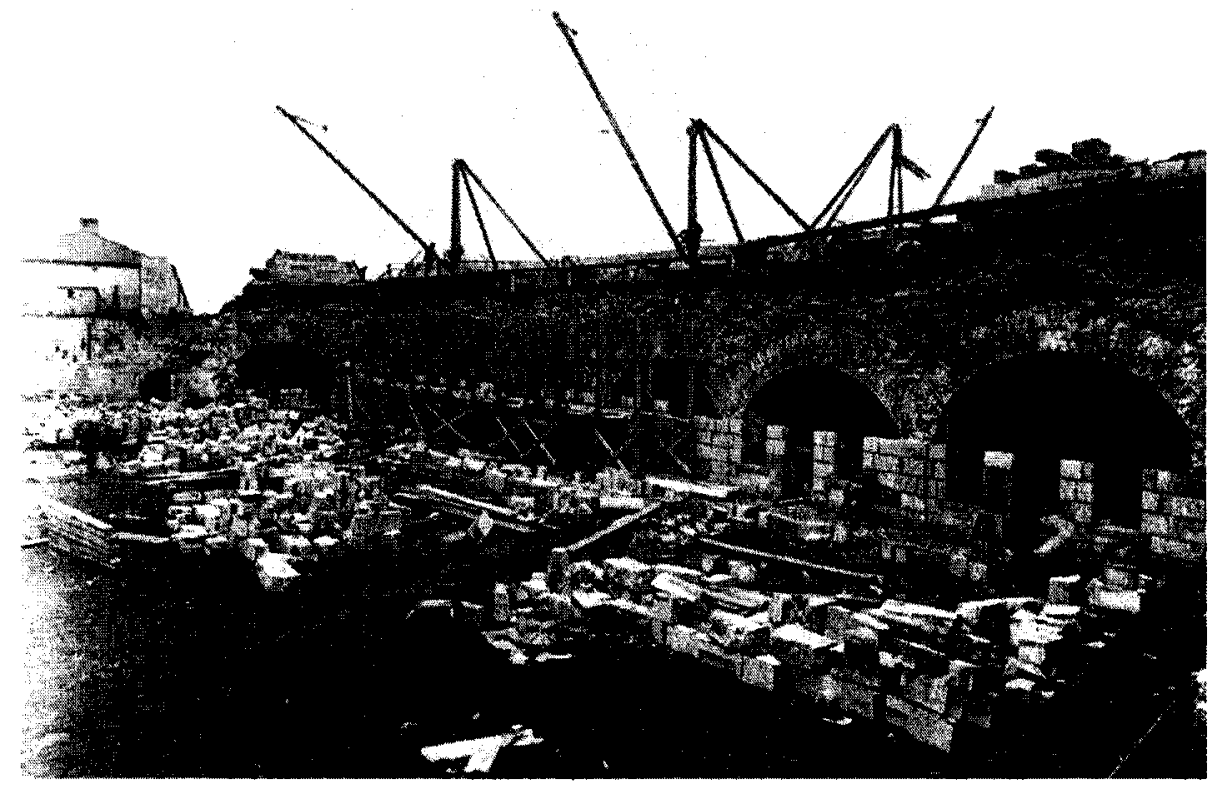

The Redoubt Casemates nearing completion during Way's reconstruction.

Image from Fort Henry National Historic Site of Canada.

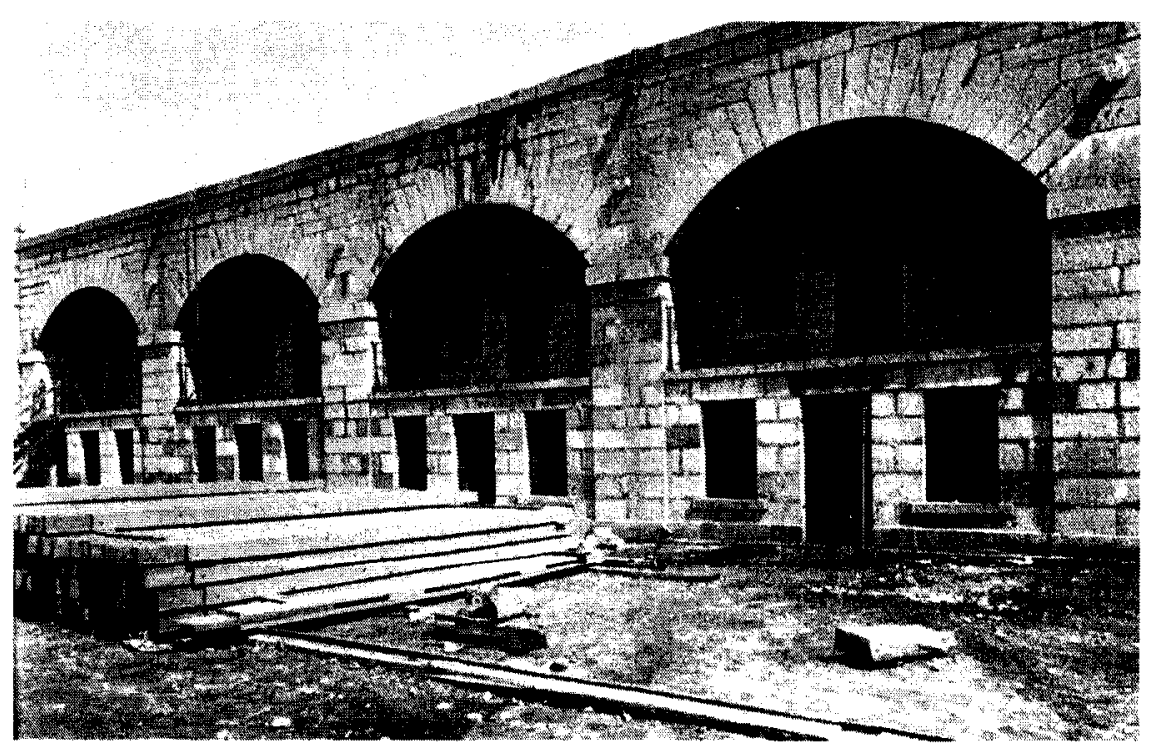


Figure 6: $\quad$ Prime Minister Mackenzie-King and Ronald L. Way enter the archway of the Redoubt, August 1st. 1938.

Mackenzie King at the opening of Fort Henry as a historic site museum on August 1, 1938 said:

I declare this Fort an Historic Site, not so much as

Prime Minister, but in the name of those unknown

British Soldiers who laid the foundation of this

land, I declare it open after one hundred years to

further the cause of peace.

Parks Canada, Date Unknown.

Image from Fort Henry National Historic Site of Canada.

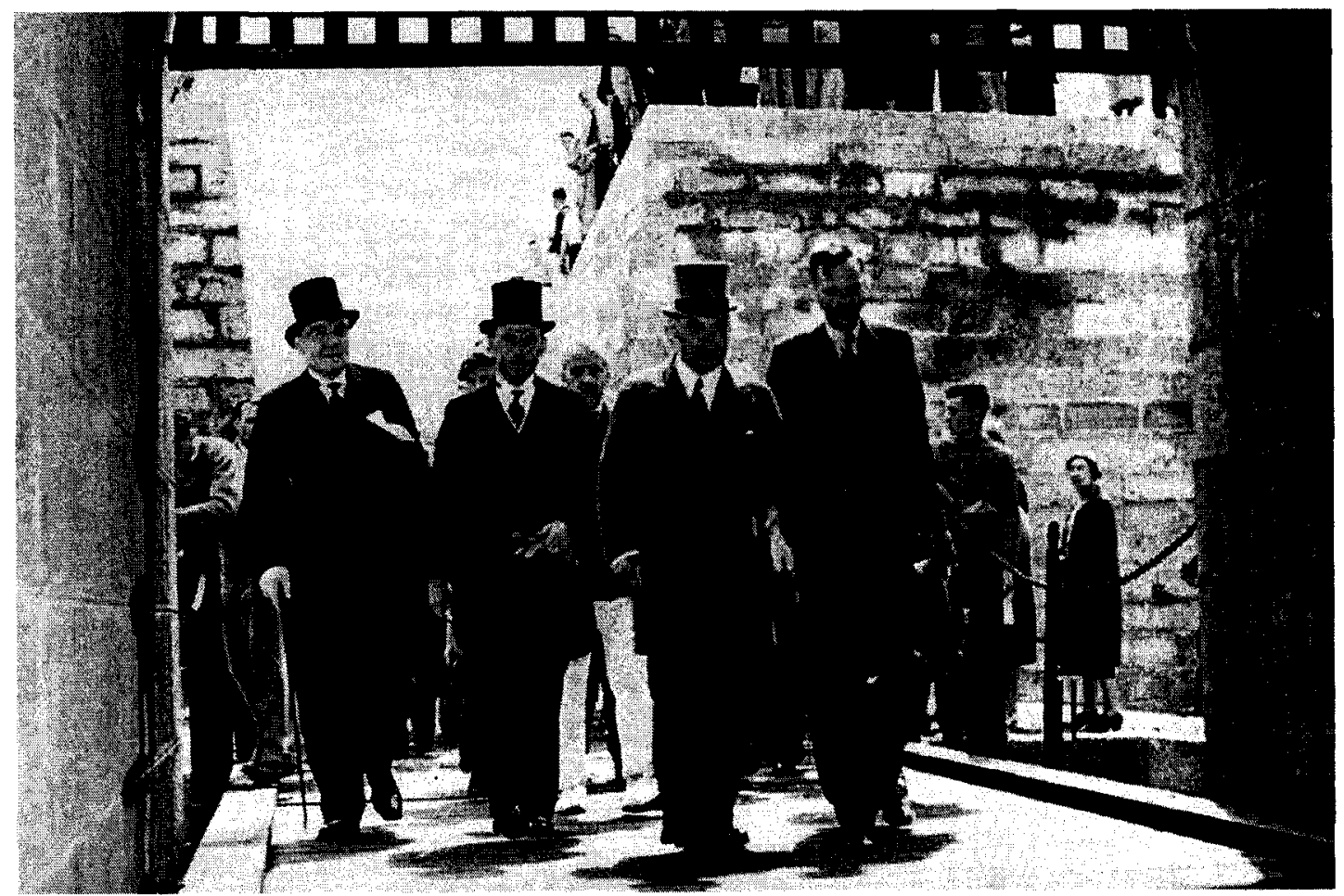


Figure 7: $\quad$ Plan of original Fort Wellington circa. 1823.

Image from Burns, 1979: 155.

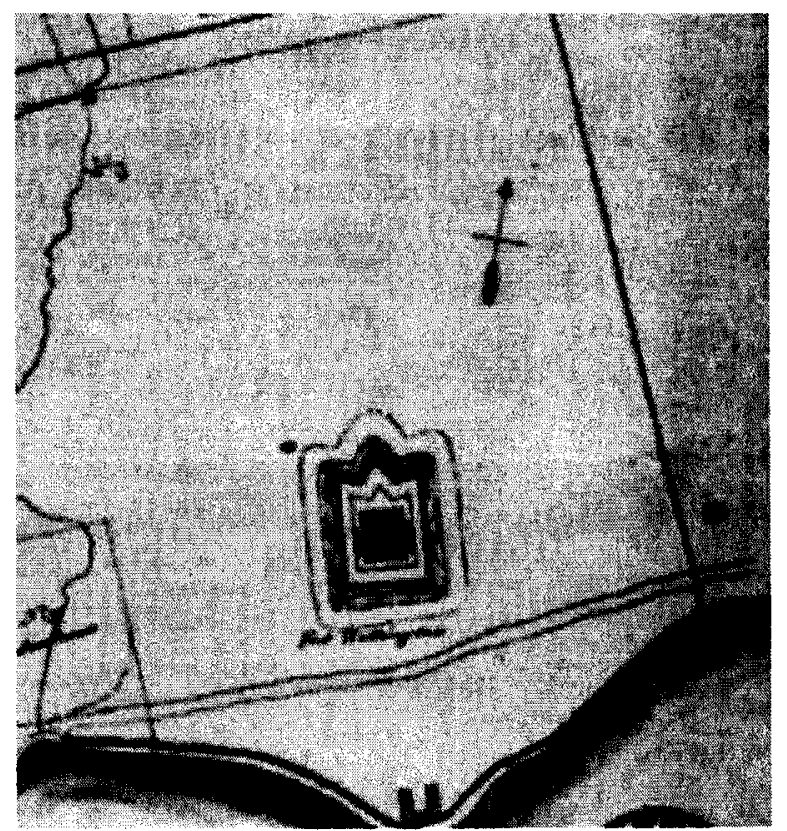


Figure 8: Plan of Fort Wellington after the 1838 reconstruction (circa. 1854). Image from William, 1970:29. Trace of Fort digitally enhanced by M.E. Novak.

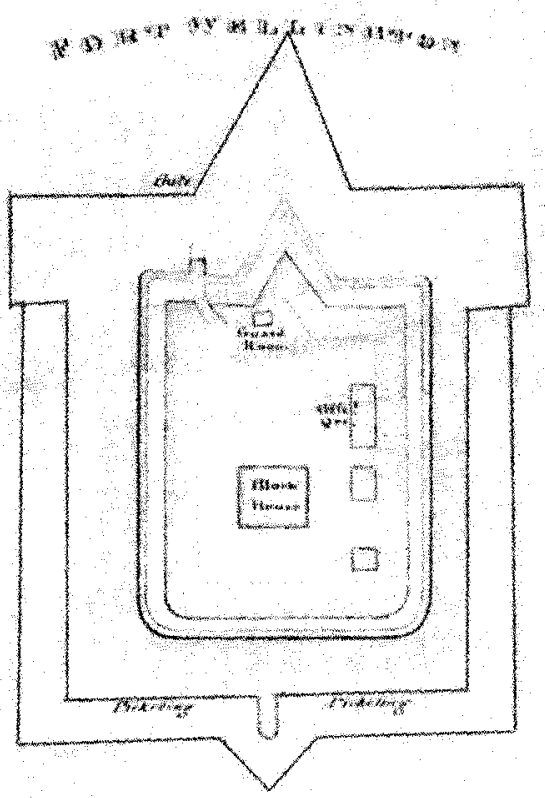

Plan of Fort Wellington National Historic Site circa. 2001. Image From Parks Canada Agency, 2001a: 33

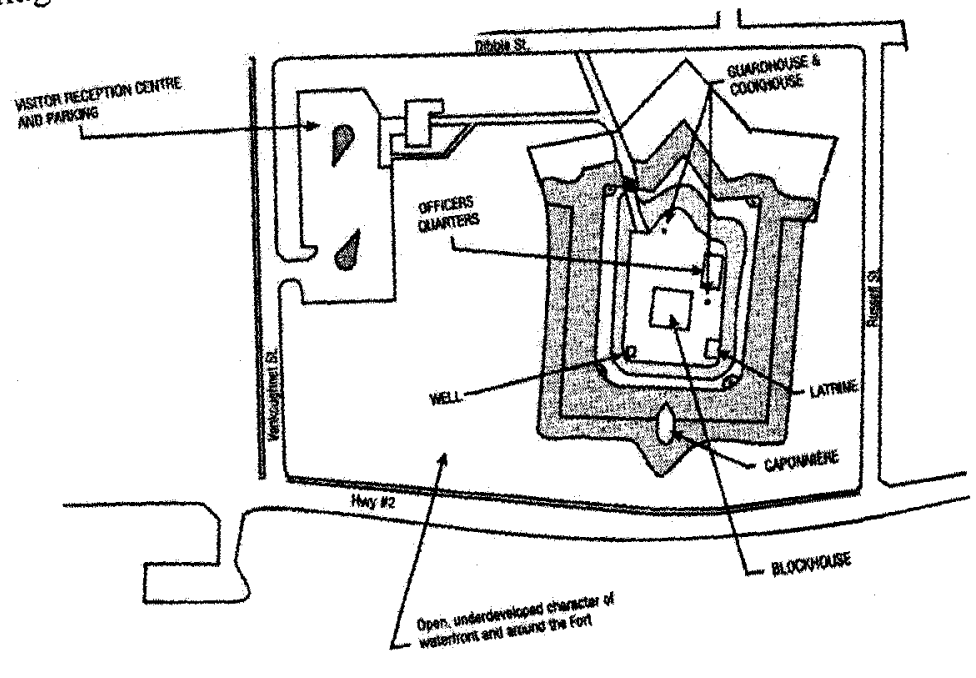


Figure 9: Marbles on display in the communal eating area of the second floor barracks room in the blockhouse of Fort Wellington. Marbles similar to those on display were recovered during the latrine excavation in the early 1990s.

Image from Novak, 2006b: 95.

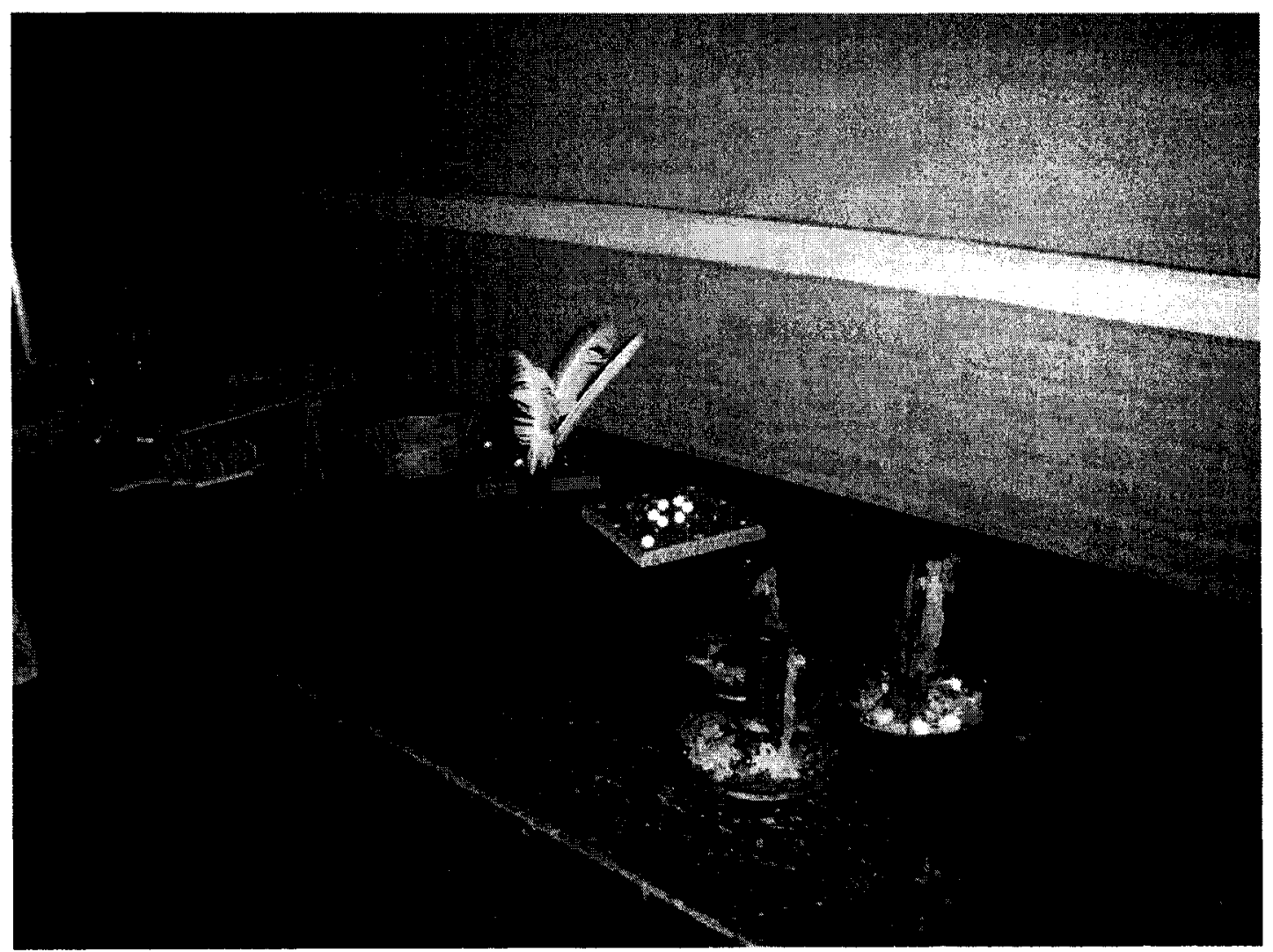


Figure 10:

A glass tumbler recovered during the latrine excavation.

Image from Sullivan, 1994: 268.

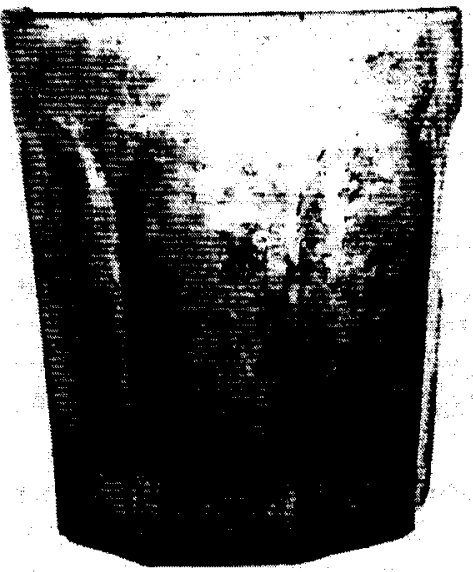

A stemmed drinking glass also recovered during the latrine excavation.

Image from Sullivan, 1994: 269.

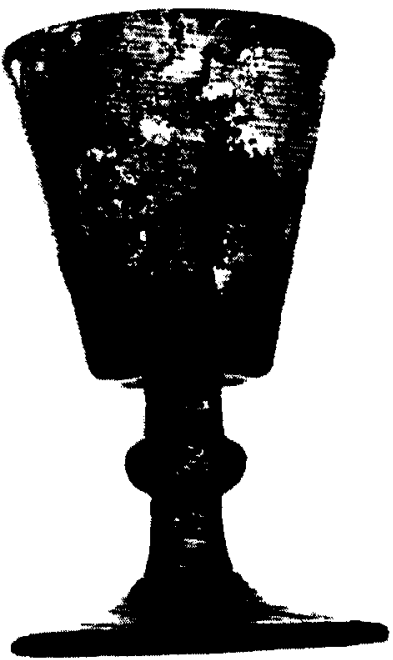

Close up of Officers' Dining Room display at Fort Wellington featuring and glass tumblers similar to those recovered during the latrine excavation.

Image from Novak, 2006b: 38.

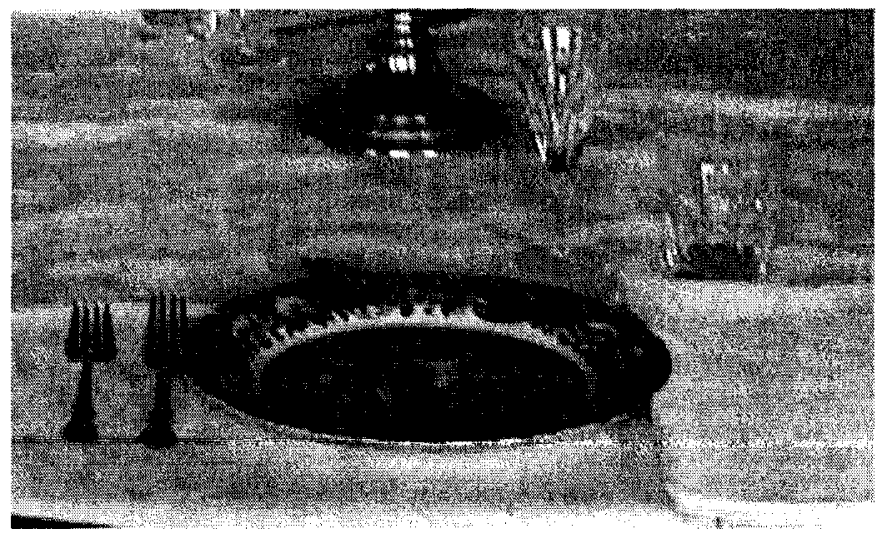


Officers' Dining Room display at Fort Wellington featuring and glass tumblers similar to those recovered during the latrine excavation.

Image from Novak, 2006b: 38.

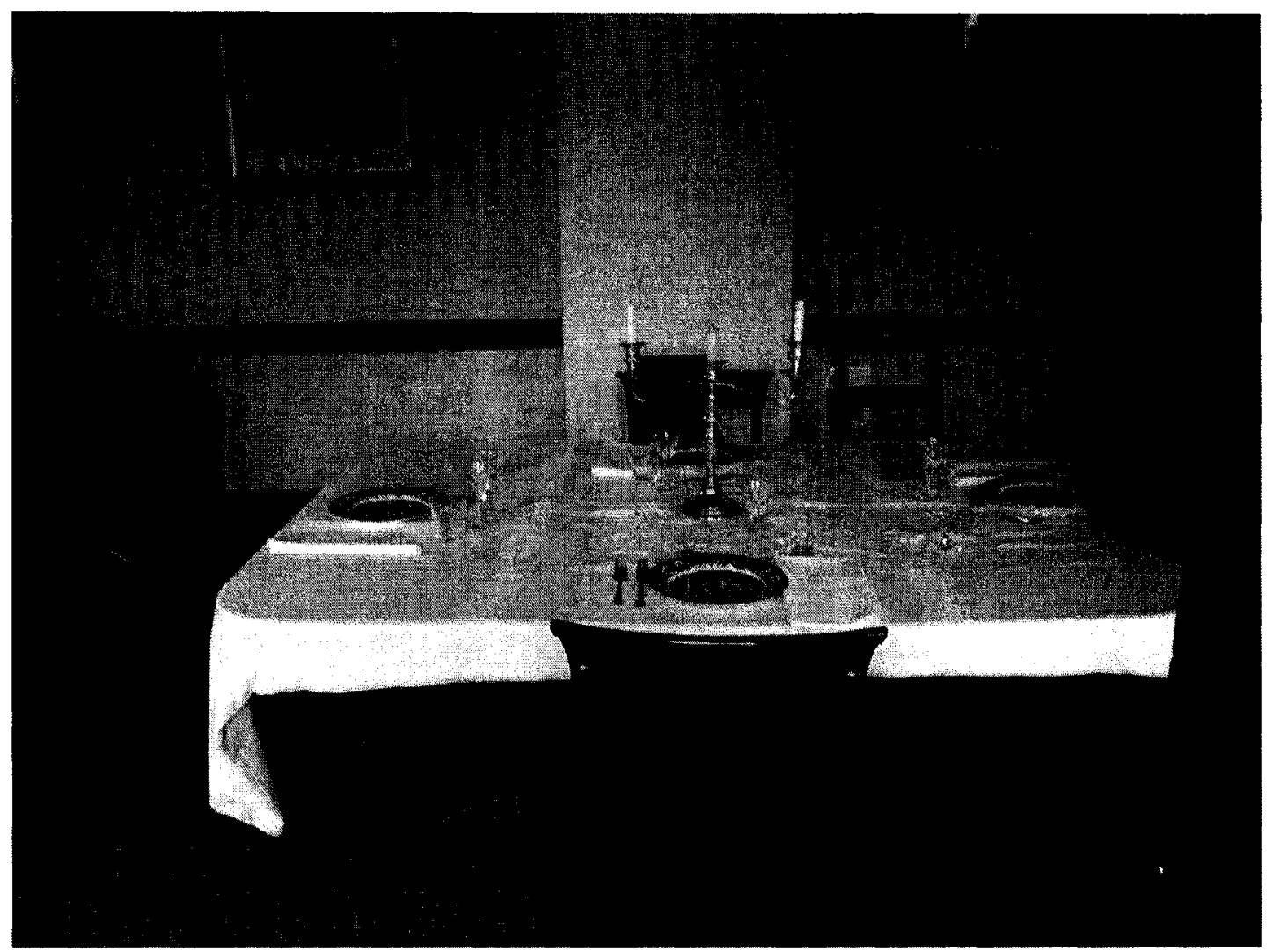


Figure 11: A portion of 1813 Fort Wellington blockhouse (dotted line) in relation to 1838 blockhouse (solid line) as determined in E.A. Wylie's 1966 archaeological investigation of the interior of the blockhouse.

Image from Wylie, 1966: 213.

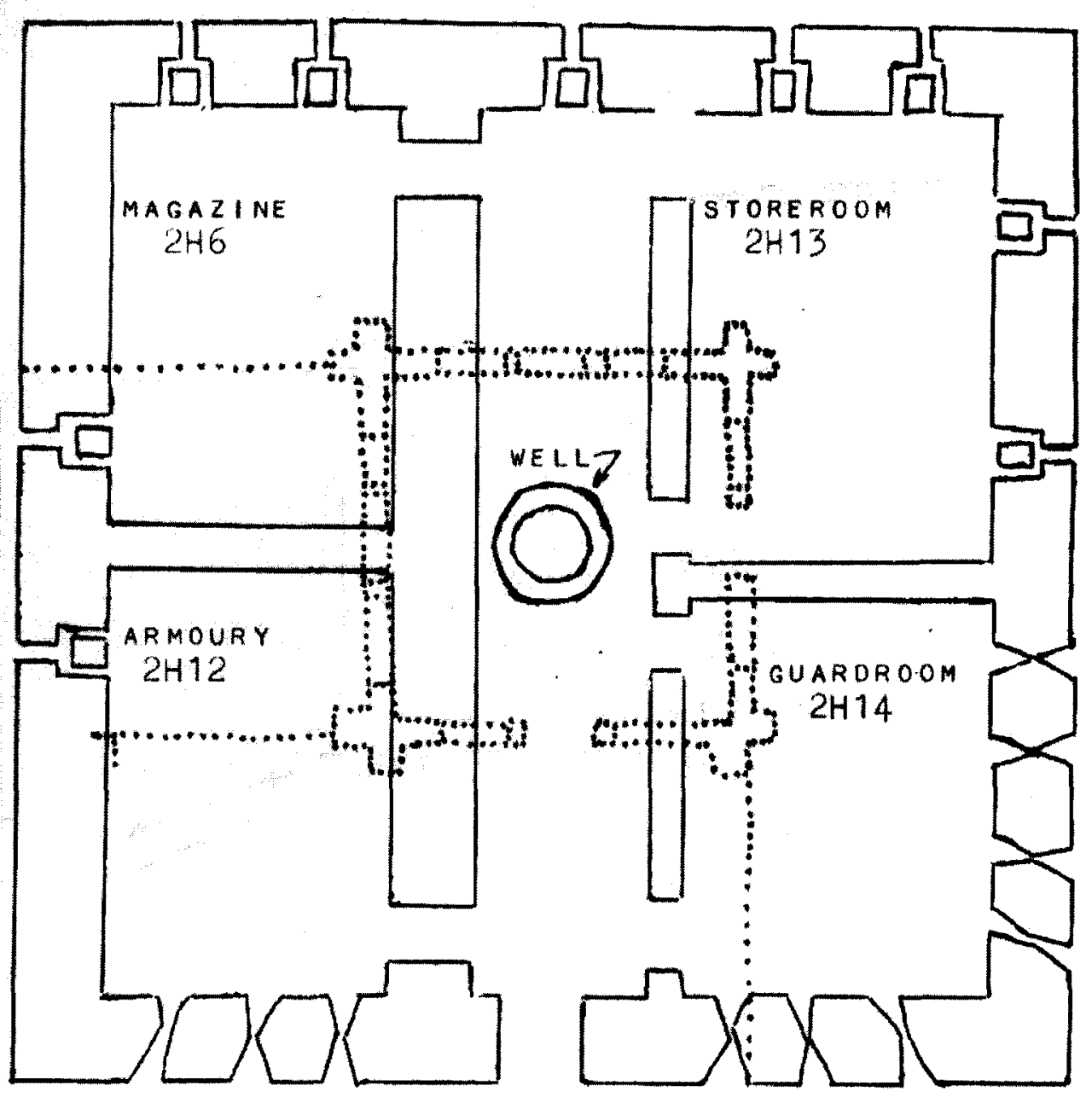


Figure 12: The Fort Wellington blockhouse circa. 1921. Note the lines in the grass surface (as indicated by the arrow) under which the 1813 blockhouse foundations lie.

Image from Wylie, 1966: 214.

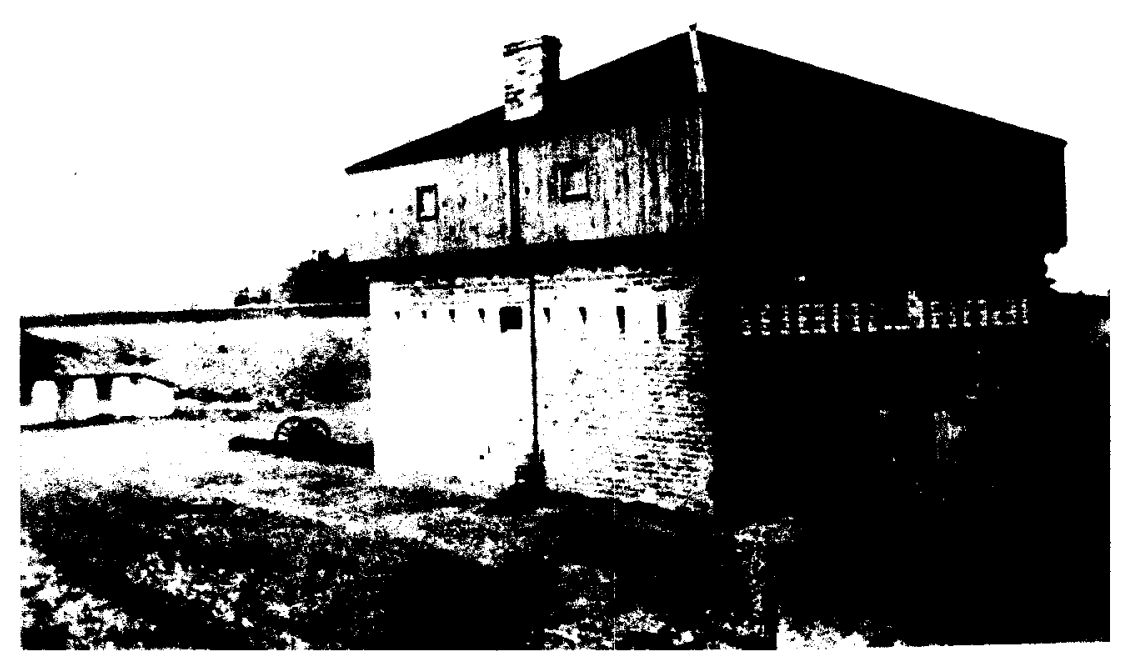

The Fort Wellington blockhouse in 2006. Note the foundation of the 1813 blockhouse is no longer visible on the grass surface.

Image from Novak, 2006b: 43.

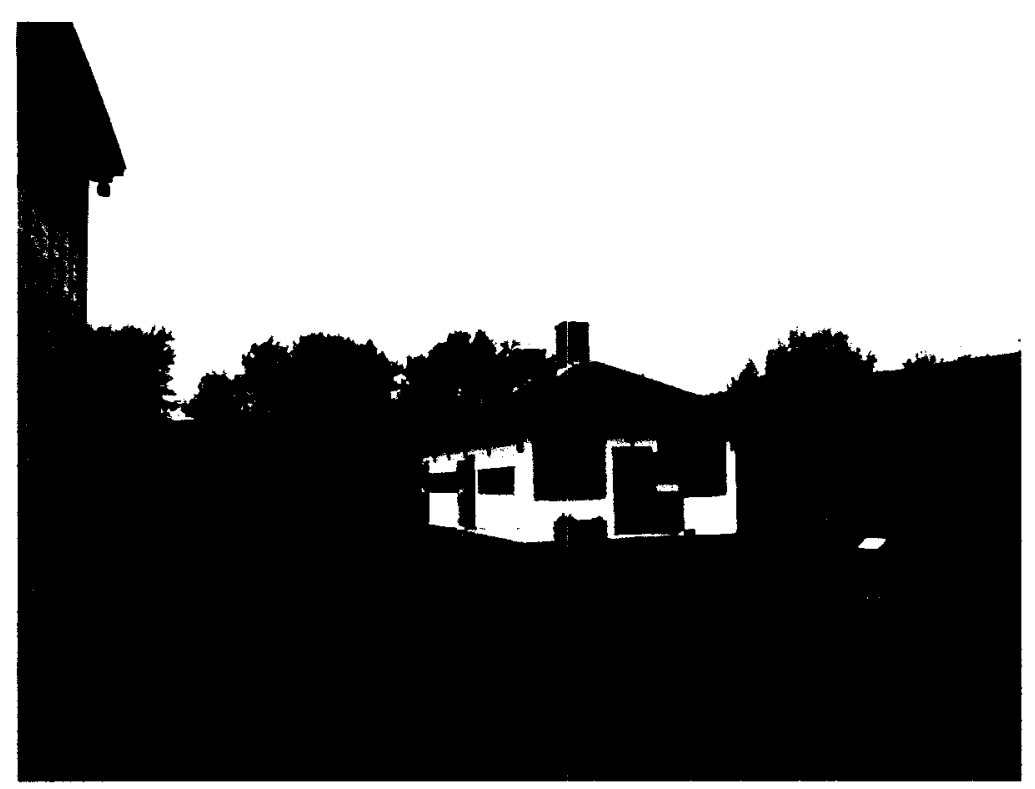


Figure 13: Image of historic shingle as discovered during a 2003 archaeological excavation at Fort Henry NHS. The sections of tin plate shingles are still pleated together and joined with wrought iron nails.

Image from Parks Canada, Tin Roof Sample.

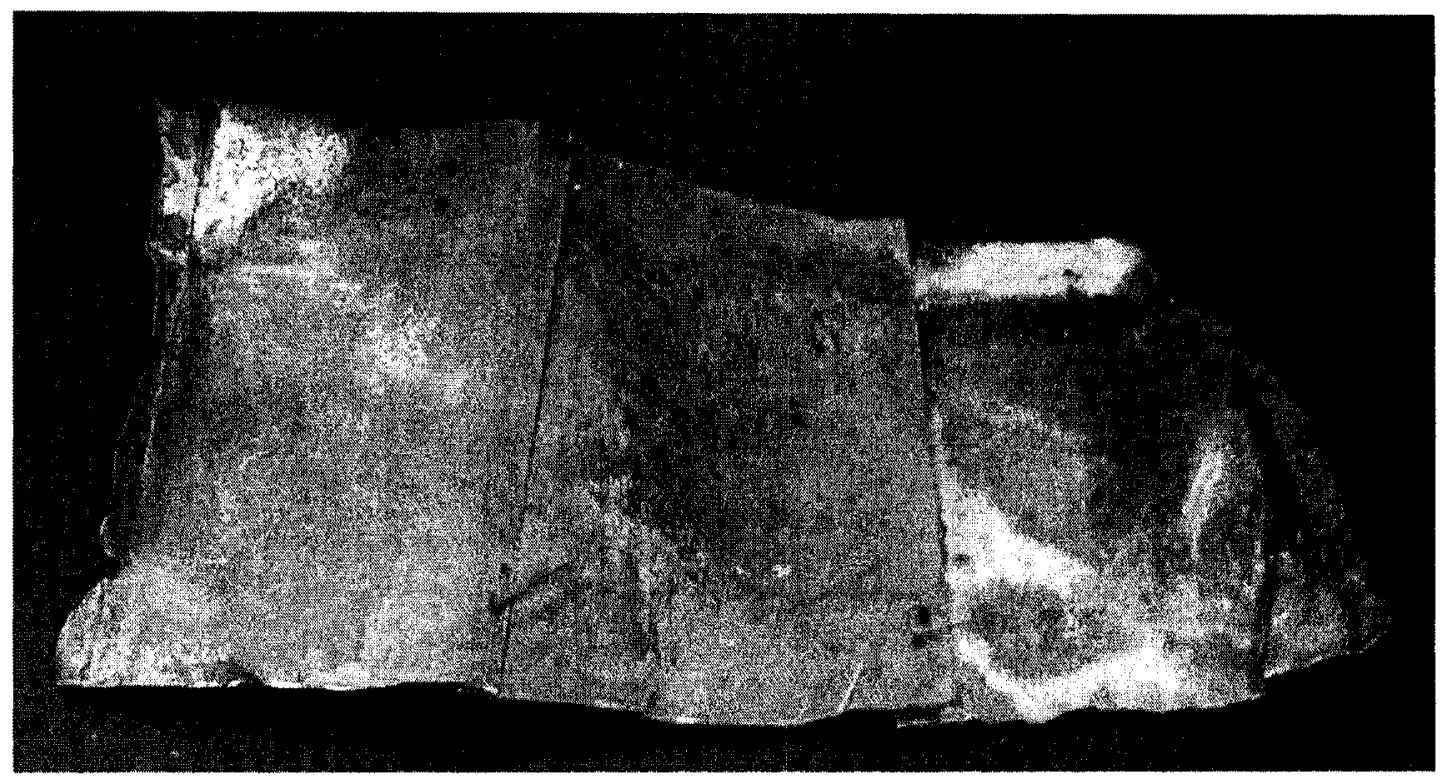


Figure 14: The Fort Henry Commissariat Range Roof prior to restoration (circa. December 2003).

Image from Parks Canada, 2003: 131H0318E.

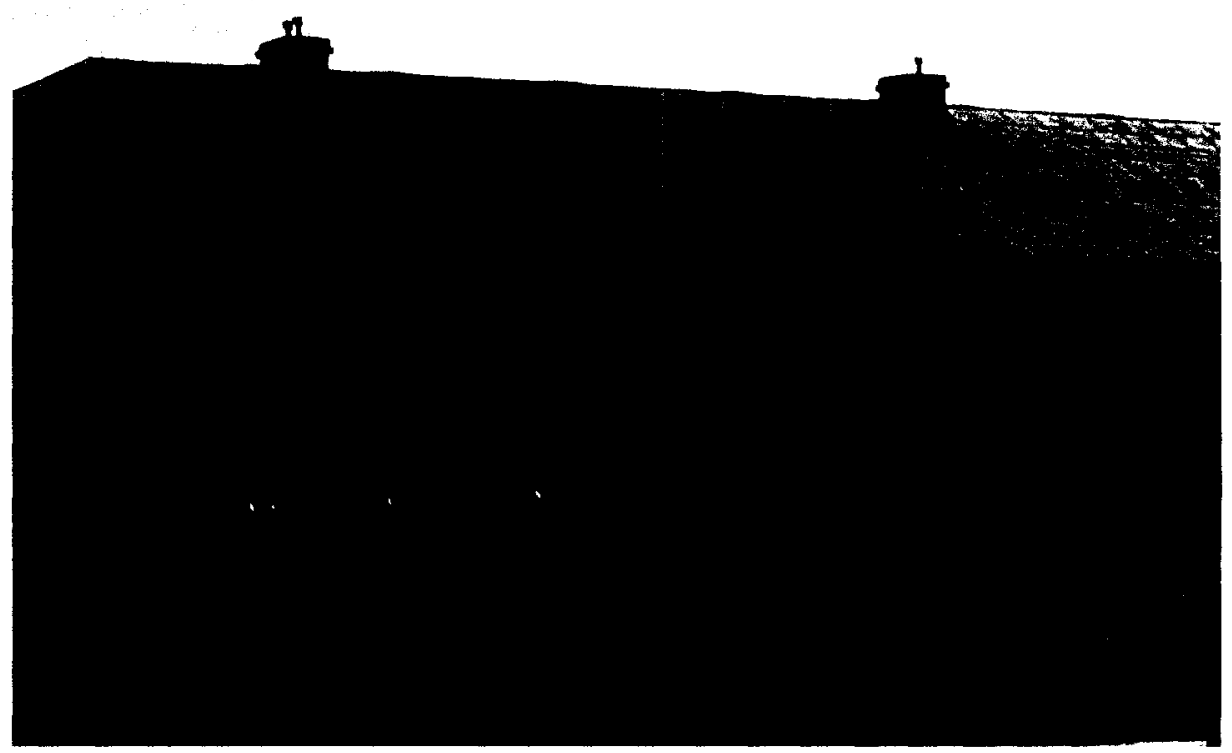

The Fort Henry Commissariat Range Roof after restoration (September, 2006).

Image from Novak, 2006a: 26.

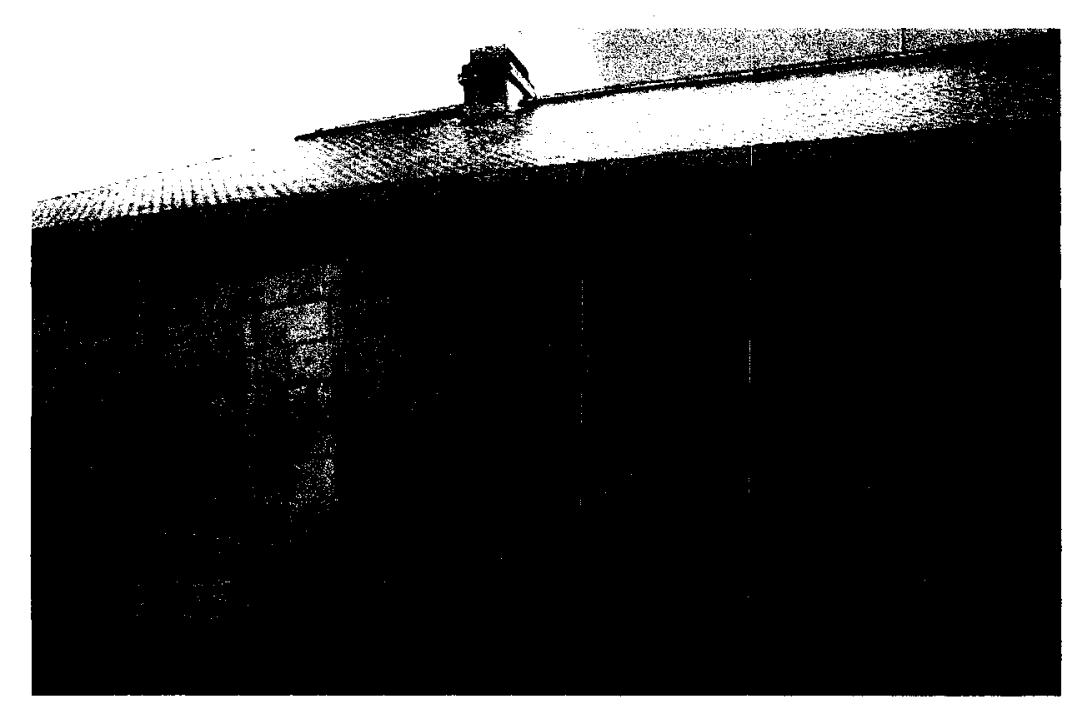


Figure 15: The Entrance Ramp at Fort Henry.

Image from Cary and Last, 2002: Cover.

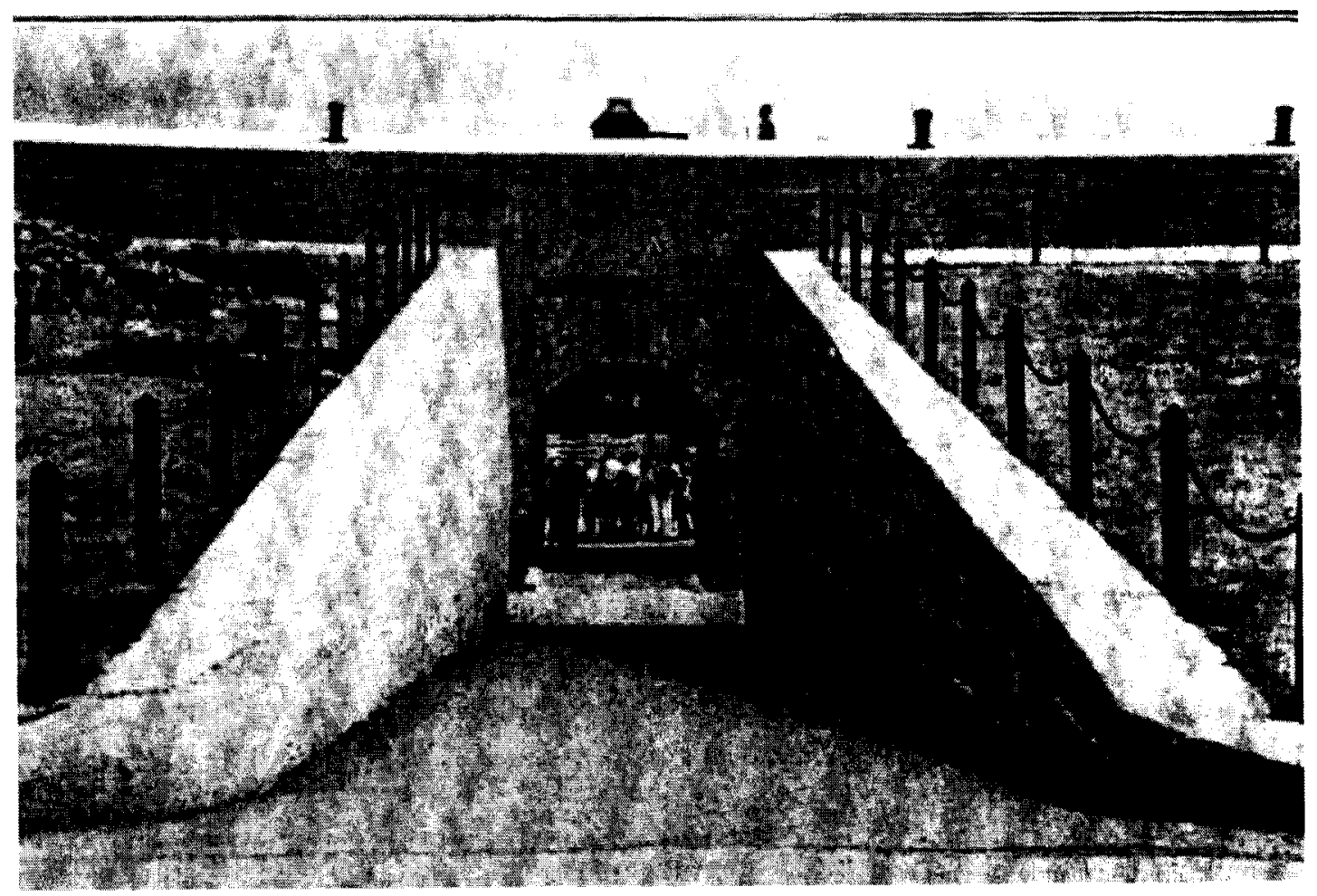


Figure 16: Bowing (outlined in red) and frost damage in the East Ramp Wall (Fort Henry) prior to the 2002 stabilization. Note the displaced blocks in the bottom three courses.

Image from Cary and Last, 2002: 7.

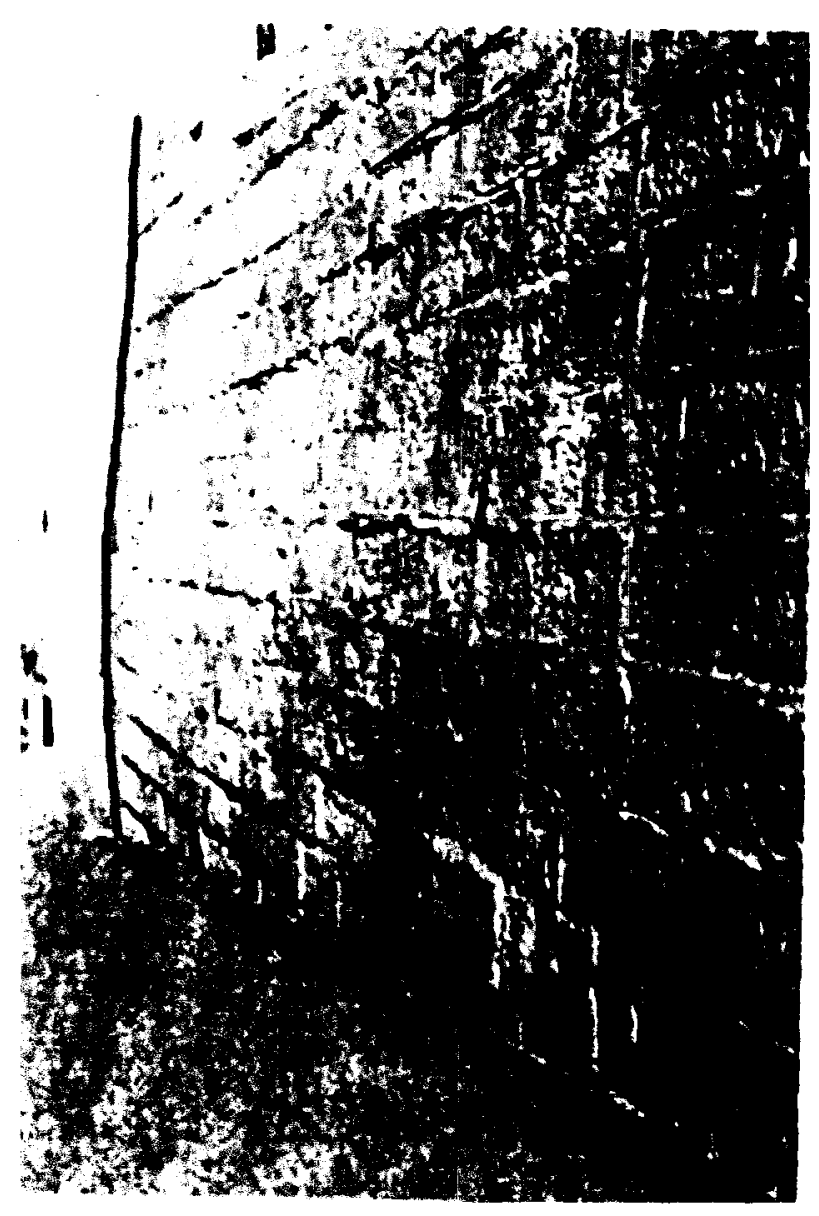


Figure 17: Standing water at Fort Henry.

Image from Parks Canada, 2003: 131H00026E.

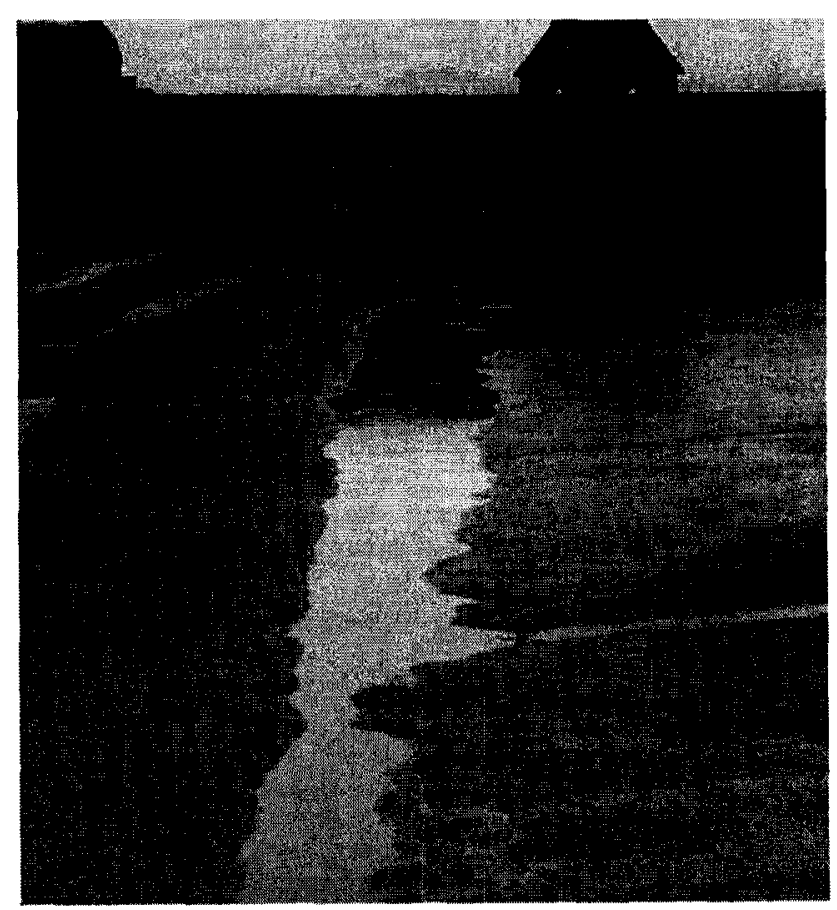

Image from Parks Canada, 2003: 131H0057E.

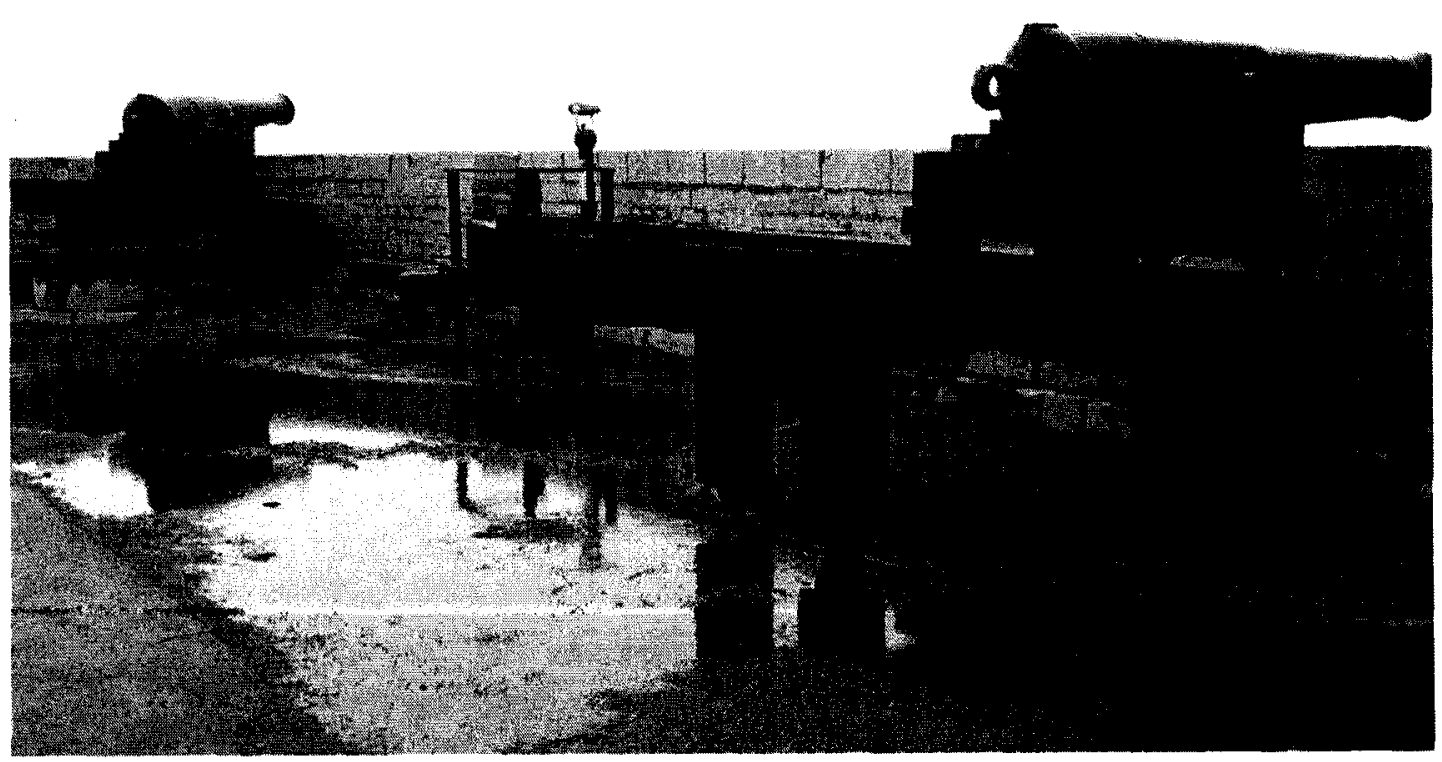

Reproduced with permission of the copyright owner. Further reproduction prohibited without permission. 
Figure 18: Historic Plan of the Officers' Quarters at Fort Henry, 1825.

Image from Cary, 2005: 14.

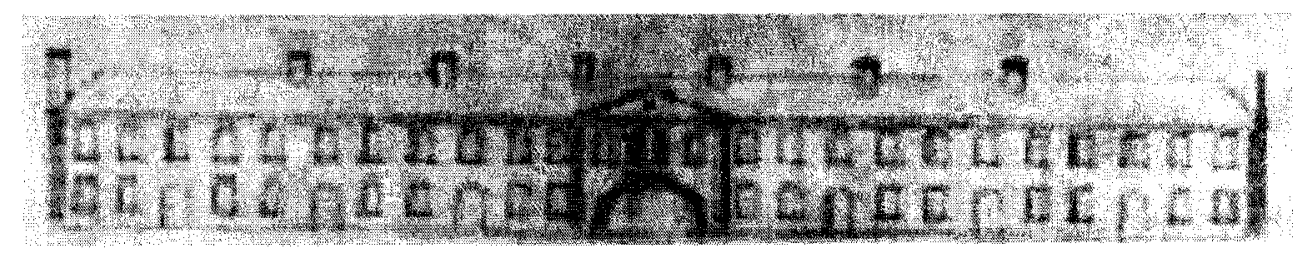


Figure 19: Image of profile of Officers Quarters Foundation, Fort Henry NHS. Image from Cary, 2005: 15.

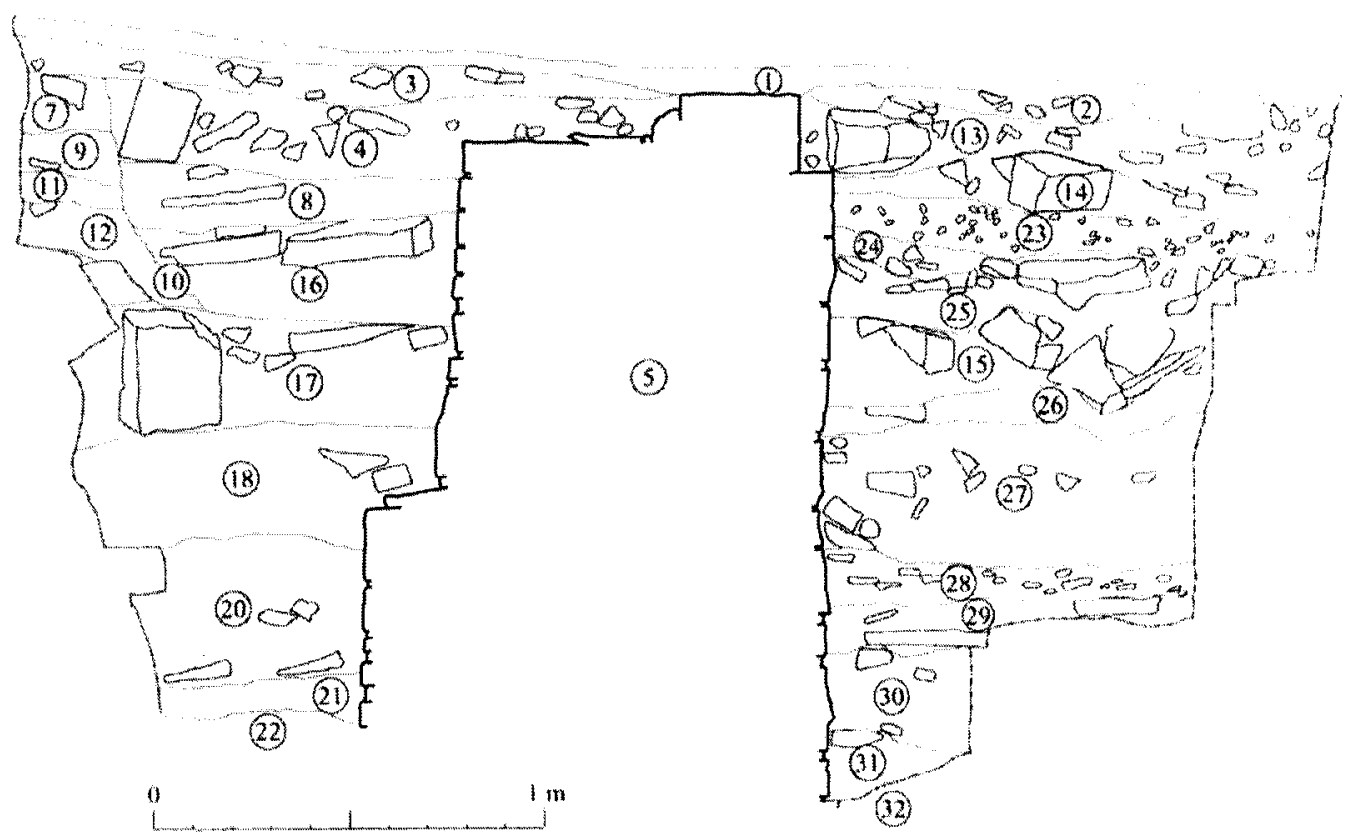


Figure 20: Examples of Wall Plaster Fragments and associated paint colours excavated from inside Officers' Quarters, Fort Henry NHS.

Image from Cary and Last, 2004: 17.

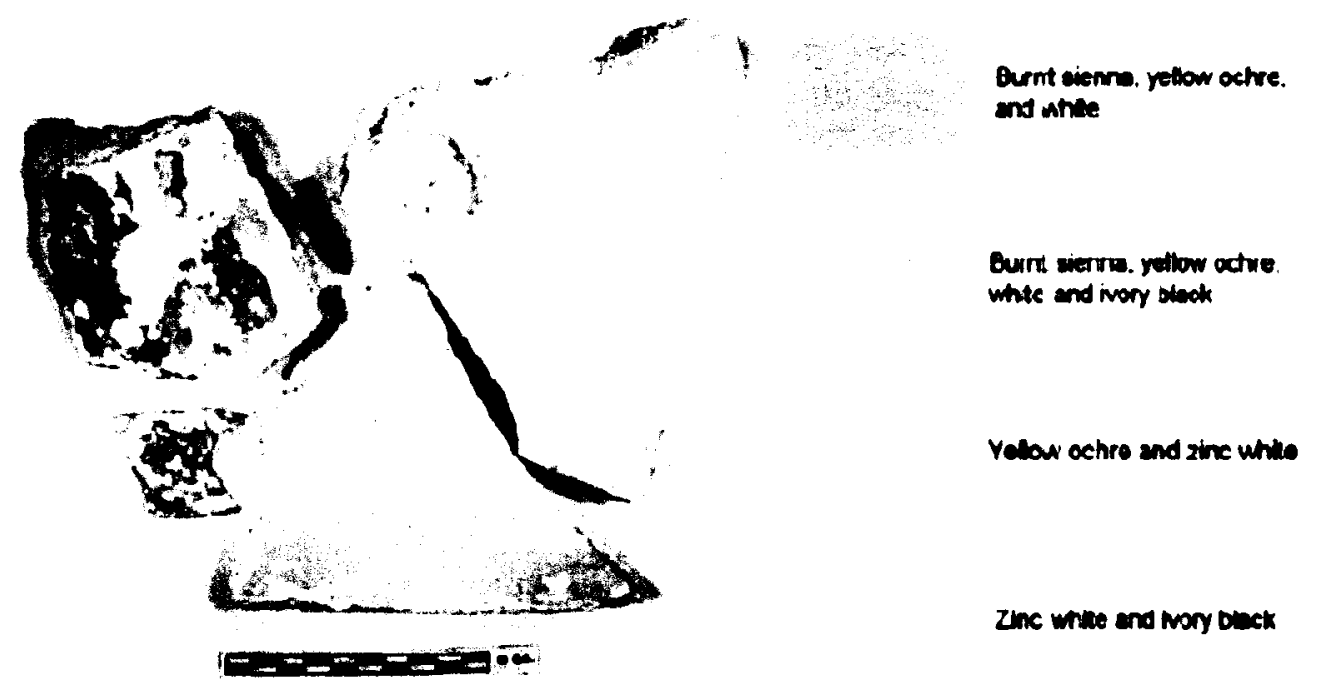


Figure 21: The installation of new infrastructure via an existing utilities corridor, Fort Henry NHS.

Image from Parks Canada, 2003: 131H0136E.

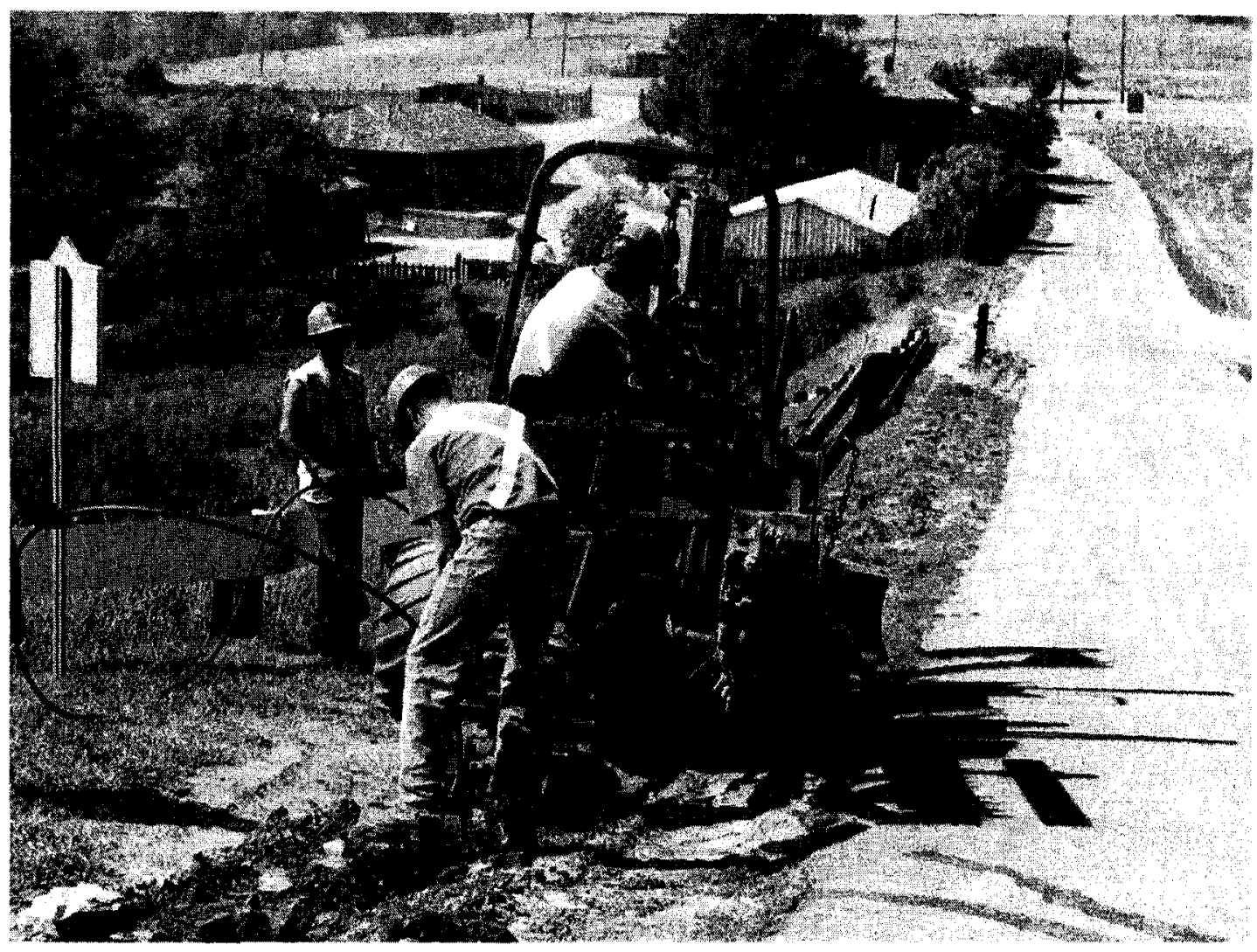




\section{Appendix I}

\section{Canada's National Parks}

\section{British Columbia}

Glacier National Park (1886)

Gulf Islands National Park Reserve (2003)

Gwaii Haanas National Park Reserve and Haida Heritage Site (1993)

Kootenay National Park (1920)

Mount Revelstoke National Park (1914)

Pacific Rim National Park Reserve (1970)

Yoho National Park (1886)

\section{Alberta}

Banff National Park (1885)

Elk Island National Park (1913)

Jasper National Park (1907)

Waterton Lakes National Park (1895)

Wood Buffalo National Park (Alberta \& Northwest Territories) (1922)

\section{Saskatchewan}

Grasslands National Park (1999)

Prince Albert National Park (1927)

\section{Manitoba}

Riding Mountain National Park (1929)

Wapusk National Park (1996)

\section{Ontario}

Bruce Peninsula National Park (1987)

Fathom Five National Marine Park (National Marine Conservation Area) (1987)

Georgian Bay Islands National Park (1929)

Point Pelee National Park (1918)

Pukaskwa National Park (1983)

St. Lawrence Islands National Park (1904)

\section{Quebec}

Forillon National Park (1970)

La Mauricie National Park (1970)

Mingan Archipelago National Park Reserve (1984)

Saguenay - St. Lawrence Marine Park (National Marine Conservation Area) (1998)

\section{New Brunswick}

Fundy National Park (1948)

Kouchibouguac National Park (1969) 
Prince Edward Island

Prince Edward Island National Park (1937)

\section{Nova Scotia}

Cape Breton Highlands National Park (1936)

Kejimkujik National Park (1965)

\section{Newfoundland and Labrador}

Gros Morne National Park (1973)

Terra Nova National Park (1957)

Torngat Mountains National Park Reserve (2005)

\section{Yukon Territory}

Ivvavik National Park (1984)

Kluane National Park and Reserve (1976)

Vuntut National Park (1995)

\section{Northwest Territories}

Aulavik National Park (1992)

Nahanni National Park Reserve (1976)

Tuktut Nogait National Park (1996)

Wood Buffalo National Park (Alberta \& Northwest Territories) (1922)

\section{Nunavut Territory}

Auyuittuq National Park (2000)

Quttinirpaaq National Park (1988)

Sirmilik National Park (1999)

Ukkusiksalik National Park (2003) 
Appendix II

\section{Expanded History: \\ Fort Henry Redoubt and Advanced Battery}

Fort Henry consists of two major components, the redoubt and the advanced battery:

The redoubt was built in 1832 using a new form of military technology for the Royal Engineers within Upper Canada. Prior to the construction of Fort Henry most military forts across the country were built with a four-sided bastion trace which provided "...enfilade fire along the entire length of the defensive work...eliminating dead zones and exposing [enemies] to... crossfire from additional bastions on the flanks" (Cary, 2005: 30). Fort Henry, however, was built using a string of "...mutually dependent artillery towers and more substantial fortifications called Redoubts..." (Cary, 2005: 30). Each redoubt acted as a detached bastion and channelled the attacking force to areas protected by either other towers or other redoubts. This change in technology meant that the concept of using an "...unbroken trace could be abandoned and the [Fort] could take an irregular shape suitable to local topography..." (Cary, 2005: 30).

The redoubt was built with a polygonal trace and features a series of two-story casemates surrounding a large parade area. On the roof surface of each row of casemates a terreplein serves as a massive gun platform (Cary, 2005: 31). The redoubt was used for a variety of functions over the years including the housing 
of military personnel during various periods of unrest and rebellion and the housing of war prisoners and war criminals during the First and Second World Wars (Cary, 2005: 35-38).

Unfortunately, almost from the beginning the redoubt was plagued with structural problems most of which stemmed from the inadequate drainage of water from within the Fort's limestone walls. The water, which would collect over the warm, rainy seasons, would quickly freeze once winter set in. As the water froze, expansion would begin a process that would literally tear the walls apart, causing huge fault lines and adding extra strain to associated walls. Although attempts were made to improve the drainage of the redoubt, by the turn of the century huge portions had either collapsed or been torn down by the occupying Canadian army because they had become unstable (Figure 14). It was not until 1936, when Ronald Way was commissioned by the provincial and federal governments to restore the Fort, that substantial attention was paid to fixing the redoubt (Cary, 2005: 38).

In 1943, the redoubt was back in the hands of the Canadian army and the Fort was used as a detention centre for Canadian soldiers charged with military offences. Although the army and Way had attempted to improve conditions of the redoubt and protect it from future disintegration, little money was ever available to have any real impact. In 1951, the parade was capped in asphalt and maintenance records began to detail the installation of various utilities and minor repairs. It was not until the beginning of the 2001 restoration program at the fort 
that the redoubt began to see any hope of salvation from continued and inevitable destruction (Cary, 2005: 39).

The advanced battery, often referred to as the Upper Fort, consists of the advanced battery parade, the east and west commissariat ranges, the scarp wall, the entrance ramp and the defensive ditch surrounding the Lower Fort (Figure 2) (Figure 7). This area serves as the entrance to the Fort and overlooks both Kingston and the st. Lawrence River. Although the advanced battery was built after the redoubt, it served as important protection for the Lower Fort and created storerooms to house goods during the Fort's occupation. The advanced battery was built between 1838 and 1843 and included the construction of a ravelin, a palisade and eventually two commissariat ranges which fully enclosed the existing Fort and demolished the last of the remaining structures of the first Fort (Cary and Last, 2004: 5). The advanced battery was used throughout the $19^{\text {th }}$ century and into the $20^{\text {th }}$ century by British garrisons, internment camp POW's and picnickers from the local Kingston area, but by 1920 it was returned to the ownership of the Canadian Army. Photographs from the period show that the entire complex had fallen into disrepair and depict dislodged downspouts and a crumbled south scarp wall. Finally, in the late $1920 \mathrm{~s}$ the Canadian Army initiated some general maintenance around the advanced battery, replacing the roofs on the commissariat buildings and re-pointing the masonry throughout to stabilize the area. These repairs meant that when Ronald Way began his restoration in 1936 , the 
advanced battery would have been in good condition and was not repaired further. Additionally, as the commissariat ranges were still held by DND for ammunition storage, they would have remained beyond Way's jurisdiction (Cary and Last, 2004: 8). 


\title{
Appendix III
}

\section{Charters Pertaining to Cultural Resource and Archaeological Management}

\author{
ICOMOS Charter for the Protection and Management of the \\ Archaeological Heritage (1990)
}

\begin{abstract}
Introduction
It is widely recognized that a knowledge and understanding of the origins and development of human societies is of fundamental importance to humanity in identifying its cultural and social roots.
\end{abstract}

The archaeological heritage constitutes the basic record of past human activities. Its protection and proper management is therefore essential to enable archaeologists and other scholars to study and interpret it on behalf of and for the benefit of present and future generations.

The protection of this heritage cannot be based upon the application of archaeological techniques alone. It requires a wider basis of professional and scientific knowledge and skills. Some elements of the archaeological heritage are components of architectural structures and in such cases must be protected in accordance with the criteria for the protection of such structures laid down in the 1966 Venice Charter on the Conservation and Restoration of Monuments and Sites. Other elements of the archaeological heritage constitute part of the living traditions of indigenous peoples, and for such sites and monuments the participation of local cultural groups is essential for their protection and preservation.

For these and other reasons the protection of the archaeological heritage must be based upon effective collaboration between professionals from many disciplines. It also requires the cooperation of government authorities, academic researchers, private or public enterprise, and the general public. This charter therefore lays down principles relating to the different aspects of archaeological heritage management. These include the responsibilities of public authorities and legislators, principles relating to the professional performance of the processes of inventorization, survey, excavation, documentation, research, maintenance, conservation, preservation, reconstruction, information, presentation, public access and use of the heritage, and the qualification of professionals involved in the protection of the archaeological heritage.

The charter has been inspired by the success of the Venice Charter as guidelines and source of ideas for policies and practice of governments as well as scholars and professionals.

The charter has to reflect very basic principles and guidelines with global validity. For this reason it cannot take into account the specific problems and possibilities of regions or 
countries. The charter should therefore be supplemented at regional and national levels by further principles and guidelines for these needs.

\section{Article 1. Definition and Introduction}

The "archaeological heritage" is that part of the material heritage in respect of which archaeological methods provide primary information. It comprises all vestiges of human existence and consists of places relating to all manifestations of human activity, abandoned structures, and remains of all kinds (including subterranean and underwater sites), together with all the portable cultural material associated with them.

\section{Article 2. Integrated Protection Policies}

The archaeological heritage is a fragile and non-renewable cultural resource. Land use must therefore be controlled and developed in order to minimize the destruction of the archaeological heritage.

Policies for the protection of the archaeological heritage should constitute an integral component of policies relating to land use, development, and planning as well as of cultural, environmental and educational policies. The policies for the protection of the archaeological heritage should be kept under continual review, so that they stay up to date. The creation of archaeological reserves should form part of such policies.

The protection of the archaeological heritage should be integrated into planning policies at international, national, regional and local levels.

Active participation by the general public must form part of policies for the protection of the archaeological heritage. This is essential where the heritage of indigenous peoples is involved. Participation must be based upon access to the knowledge necessary for decision-making. The provision of information to the general public is therefore an important element in integrated protection.

\section{Article 3. Legislation and Economy}

The protection of the archaeological heritage should be considered as a moral obligation upon all human beings; it is also a collective public responsibility. This obligation must be acknowledged through relevant legislation and the provision of adequate funds for the supporting programmes necessary for effective heritage management.

The archaeological heritage is common to all human society and it should therefore be the duty of every country to ensure that adequate funds are available for its protection.

Legislation should afford protection to the archaeological heritage that is appropriate to the needs, history, and traditions of each country and region, providing for in situ protection and research needs. 
Legislation should be based on the concept of the archaeological heritage as the heritage of all humanity and of groups of peoples, and not restricted to any individual person or nation.

Legislation should forbid the destruction, degradation or alteration through changes of any archaeological site or monument or to their surroundings without the consent of the relevant archaeological authority.

Legislation should in principle require full archaeological investigation and documentation in cases where the destruction of the archaeological heritage is authorized.

Legislation should require, and make provision for, the proper maintenance, management and conservation of the archaeological heritage. Adequate legal sanctions should be prescribed in respect of violations of archaeological heritage legislation.

If legislation affords protection only to those elements of the archaeological heritage which are registered in a selective statutory inventory, provision should be made for the temporary protection of unprotected or newly discovered sites and monuments until an archaeological evaluation can be carried out.

Development projects constitute one of the greatest physical threats to the archaeological heritage. A duty for developers to ensure that archaeological heritage impact studies are carried out before development schemes are implemented, should therefore be embodied in appropriate legislation, with a stipulation that the costs of such studies are to be included in project costs. The principle should also be established in legislation that development schemes should be designed in such a way as to minimize their impact upon the archaeological heritage.

\section{Article 4. Survey}

The protection of the archaeological heritage must be based upon the fullest possible knowledge of its extent and nature. General survey of archaeological resources is therefore an essential working tool in developing strategies for the protection of the archaeological heritage. Consequently archaeological survey should be a basic obligation in the protection and management of the archaeological heritage.

At the same time, inventories constitute primary resource databases for scientific study and research. The compilation of inventories should therefore be regarded as a continuous, dynamic process. It follows that inventories should comprise information at various levels of significance and reliability, since even superficial knowledge can form the starting point for protectional measures. 


\section{Article 5. Investigation}

Archaeological knowledge is based principally on the scientific investigation of the archaeological heritage. Such investigation embraces the whole range of methods from non-destructive techniques through sampling to total excavation.

It must be an overriding principle that the gathering of information about the archaeological heritage should not destroy any more archaeological evidence than is necessary for the protectional or scientific objectives of the investigation. Nondestructive techniques, aerial and ground survey, and sampling should therefore be encouraged wherever possible, in preference to total excavation.

As excavation always implies the necessity of making a selection of evidence to be documented and preserved at the cost of losing other information and possibly even the total destruction of the monument, a decision to excavate should only be taken after thorough consideration.

Excavation should be carried out on sites and monuments threatened by development, land-use change, looting, or natural deterioration.

In exceptional cases, unthreatened sites may be excavated to elucidate research problems or to interpret them more effectively for the purpose of presenting them to the public. In such cases excavation must be preceded by thorough scientific evaluation of the significance of the site. Excavation should be partial, leaving a portion undisturbed for future research.

A report conforming to an agreed standard should be made available to the scientific community and should be incorporated in the relevant inventory within a reasonable period after the conclusion of the excavation.

Excavations should be conducted in accordance with the principles embodied in the 1956 UNESCO Recommendations on International Principles Applicable to Archaeological Excavations and with agreed international and national professional standards.

\section{Article 6. Maintenance and Conservation}

The overall objective of archaeological heritage management should be the preservation of monuments and sites in situ, including proper long-term conservation and curation of all related records and collections etc. Any transfer of elements of the heritage to new locations represents a violation of the principle of preserving the heritage in its original context. This principle stresses the need for proper maintenance, conservation and management. It also asserts the principle that the archaeological heritage should not be exposed by excavation or left exposed after excavation if provision for its proper maintenance and management after excavation cannot be guaranteed. 
Local commitment and participation should be actively sought and encouraged as a means of promoting the maintenance of the archaeological heritage. This principle is especially important when dealing with the heritage of indigenous peoples or local cultural groups. In some cases it may be appropriate to entrust responsibility for the protection and management of sites and monuments to indigenous peoples.

Owing to the inevitable limitations of available resources, active maintenance will have to be carried out on a selective basis. It should therefore be applied to a sample of the diversity of sites and monuments, based upon a scientific assessment of their significance and representative character, and not confined to the more notable and visually attractive monuments.

The relevant principles of the 1956 UNESCO Recommendations should be applied in respect of the maintenance and conservation of the archaeological heritage.

\section{Article 7. Presentation, Information, Reconstruction}

The presentation of the archaeological heritage to the general public is an essential method of promoting an understanding of the origins and development of modern societies. At the same time it is the most important means of promoting an understanding of the need for its protection.

Presentation and information should be conceived as a popular interpretation of the current state of knowledge, and it must therefore be revised frequently. It should take account of the multifaceted approaches to an understanding of the past.

Reconstructions serve two important functions: experimental research and interpretation. They should, however, be carried out with great caution, so as to avoid disturbing any surviving archaeological evidence, and they should take account of evidence from all sources in order to achieve authenticity. Where possible and appropriate, reconstructions should not be built immediately on the archaeological remains, and should be identifiable as such.

\section{Article 8. Professional Qualifications}

High academic standards in many different disciplines are essential in the management of the archaeological heritage. The training of an adequate number of qualified professionals in the relevant fields of expertise should therefore be an important objective for the educational policies in every country. The need to develop expertise in certain highly specialized fields calls for international cooperation. Standards of professional training and professional conduct should be established and maintained.

The objective of academic archaeological training should take account of the shift in conservation policies from excavation to in situ preservation. It should also take into account the fact that the study of the history of indigenous peoples is as important in 
preserving and understanding the archaeological heritage as the study of outstanding monuments and sites.

The protection of the archaeological heritage is a process of continuous dynamic development. Time should therefore be made available to professionals working in this field to enable them to update their knowledge. Postgraduate training programmes should be developed with special emphasis on the protection and management of the archaeological heritage.

\section{Article 9. International Cooperation}

The archaeological heritage is the common heritage of all humanity. International cooperation is therefore essential in developing and maintaining standards in its management.

There is an urgent need to create international mechanisms for the exchange of information and experience among professionals dealing with archaeological heritage management. This requires the organization of conferences, seminars, workshops, etc. at global as well as regional levels, and the establishment of regional centres for postgraduate studies. ICOMOS, through its specialized groups, should promote this aspect in its medium- and long-term planning.

International exchanges of professional staff should also be developed as a means of raising standards of archaeological heritage management.

Technical assistance programmes in the field of archaeological heritage management should be developed under the auspices of ICOMOS.

This Charter, written by the International Committee on Archaeological Heritage Management (ICAHM), a specialized committee of ICOMOS, was approved by the ICOMOS General Assembly, meeting in Lausanne, Switzerland, in October 1990. 
Australia

\section{The Burra Charter: The Australia ICOMOS charter for the conservation of places of cultural significance (1999) (excerpts)}

\section{Preamble}

Considering the International Charter for the Conservation and Restoration of Monuments and Sites (Venice 1964), and the Resolutions of the 5th General Assembly of the International Council on Monuments and Sites (ICOMOS) (Moscow 1978), the Burra Charter was adopted by Australia ICOMOS (the Australian National Committee of ICOMOS) on 19 August 1979 at Burra, South Australia. Revisions were adopted on 23 February 1981, 23 April 1988 and 26 November 1999.

The Burra Charter provides guidance for the conservation and management of places of cultural significance (cultural heritage places), and is based on the knowledge and experience of Australia ICOMOS members.

Conservation is an integral part of the management of places of cultural significance and is an ongoing responsibility.

\section{Who is the Charter for?}

The Charter sets a standard of practice for those who provide advice, make decisions about, or undertake works to places of cultural significance, including owners, managers and custodians.

\section{Using the Charter}

The Charter should be read as a whole. Many articles are interdependent. Articles in the Conservation Principles section are often further developed in the Conservation Processes and Conservation Practice sections. Headings have been included for ease of reading but do not form part of the Charter.

The Charter is self-contained, but aspects of its use and application are further explained in the following Australia ICOMOS documents:

- Guidelines to the Burra Charter: Cultural Significance;

- Guidelines to the Burra Charter: Conservation Policy;

- Guidelines to the Burra Charter: Procedures for Undertaking Studies and

Reports;

- Code on the Ethics of Coexistence in Conserving Significant Places. 


\section{What places does the Charter apply to?}

The Charter can be applied to all types of places of cultural significance including natural, indigenous and historic places with cultural values.

The standards of other organisations may also be relevant. These include the Australian Natural Heritage Charter and the Draft Guidelines for the Protection, Management and Use of Aboriginal and Torres Strait Islander Cultural Heritage Places.

\section{Why conserve?}

Places of cultural significance enrich people's lives, often providing a deep and inspirational sense of connection to community and landscape, to the past and to lived experiences. They are historical records, that are important as tangible expressions of Australian identity and experience. Places of cultural significance reflect the diversity of our communities, telling us about who we are and the past that has formed us and the Australian landscape. They are irreplaceable and precious.

These places of cultural significance must be conserved for present and future generations.

The Burra Charter advocates a cautious approach to change: do as much as necessary to care for the place and to make it useable, but otherwise change it as little as possible so that its cultural significance is retained.

\section{Article 28: Disturbance of Fabric}

Disturbance of significant fabric for study, or to obtain evidence, should be minimised. Study of a place by any disturbance of the fabric, including archaeological excavation, should only be undertaken to provide data essential for decisions on the conservation of the place, or to obtain important evidence about to be lost or made inaccessible.

Investigation of a place which requires disturbance of the fabric, apart from that necessary to make decisions, may be appropriate provided that it is consistent with the policy for the place. Such investigation should be based on important research questions which have potential to substantially add to knowledge, which cannot be answered in other ways and which minimises disturbance of significant fabric 


\section{New Zealand}

\section{Charter for the Conservation of Places of Cultural Heritage Value}

\section{Preamble}

New Zealand retains a unique assemblage of places of cultural heritage value relating to its indigenous and its more recent peoples. These areas, landscapes and features, buildings, structures and gardens, archaeological and traditional sites, and sacred places and monuments are treasures of distinctive value. New Zealand shares a general responsibility with the rest of humanity to safeguard its cultural heritage for present and future generations. More specifically, New Zealand peoples have particular ways of perceiving, conserving and relating to their cultural heritage.

Following the spirit of the International Charter for the Conservation and Restoration of Monuments and Sites (the Venice Charter 1966), this charter sets our principles to guide the conservation of places of cultural heritage value in New Zealand. It is intended as a frame of reference for all those who, as owners, territorial authorities, tradespersons or professionals, are involved in the different aspects of such work. It aims to provide guidelines for community leaders, organisations and individuals concerned with conservation issues. It is a statement of professional practice for members of ICOMOS New Zealand.

Each section of the charter should be read in the light of all the others. Definitions of terms used are provided in section 22.

Accordingly this charter has been adopted by the New Zealand National Committee of the International Council on Monuments and Sites at its Annual General Meeting on 4 October 1992.

\section{The Purpose of Conservation}

The purpose of conservation is to care for places of cultural heritage value, their structures, materials and cultural meaning. In general, such places:

i. have lasting values and can be appreciated in their own right;

ii. teach us about the past and the culture of those who came before us;

iii. provide the context for community identity whereby people relate to the land and to those who have gone before;

iv. provide variety and contrast in the modern world and a measure against which we can compare the achievements of today; and

$\mathrm{v}$. provide visible evidence of the continuity between past, present and future. 


\section{Indigenous Cultural Heritage}

The indigenous heritage of Maori and Moriori relates to family, local and tribal groups and associations. It is inseparable from identity and well-being and has particular cultural meanings.

The Treaty of Waitangi is the historical basis for indigenous guardianship. It recognises the indigenous people as exercising responsibility for their treasures, monuments and sacred places. This interest extends beyond current legal ownership wherever such heritage exists. Particular knowledge of heritage values is entrusted to chosen guardians. The conservation of places of indigenous cultural heritage value therefore is conditional on decisions made in the indigenous community, and should proceed only in this context. Indigenous conservation precepts are fluid and take account of the continuity of life and the needs of the present as well as the responsibilities of guardianship and association with those who have gone before. In particular, protocols of access, authority and ritual are handled at a local level. General principles of ethics and social respect affirm that such protocols should be observed.

\section{Conservation Practice}

Appropriate conservation professionals should be involved in all aspects of conservation work. Indigenous methodologies should be applied as appropriate and may vary from place to place. Conservation results should be in keeping with their cultural content. All necessary consents and permits should be obtained.

Conservation projects should include the following:

definition of the cultural heritage value of the place, which requires prior researching of any documentary and oral history, a detailed examination of the place, and the recording of its physical condition;

community consultation, continuing throughout a project as appropriate; preparation of a plan which meets the conservation principles of this charter; the implementation of any planned work; and

the documentation of any research, recording and conservation work, as it proceeds.

\section{General Principles}

\section{Conservation Method}

Conservation should:

i. make use of all relevant conservation values, knowledge, disciplines, arts and crafts;

ii. show the greatest respect for, and involve the least possible loss of, material of cultural heritage value;

iii. involve the least degree of intervention consistent with long term care and the principles of this charter; 
iv. take into account the needs, abilities and resources of the particular communities; and

v. be fully documented and recorded.

\section{Respect for existing evidence}

The evidence of time and the contributions of all periods should be respected in conservation. The material of a particular period may be obscured or removed if assessment shows that this would not diminish the cultural heritage value of the place. In these circumstances such material should be documented before it is obscured or removed.

\section{Setting}

The historical setting of a place should be conserved with the place itself. If the historical setting non longer exists, construction of a setting based on physical and documentary evidence should be the aim. The extent of the appropriate setting may be affected by constraints other than heritage value.

\section{Risk Mitigation}

All places of cultural heritage value should be assessed as to their potential risk from any natural process or event. Where a significant risk is determined, appropriate action to minimise the risk should be undertaken. Where appropriate, a risk mitigation plan should be prepared.

\section{Relocation}

The site of an historic structure is usually an integral part of its cultural heritage value. Relocation, however, can be a legitimate part of the conservation process where assessment shows that:

i. the site is not of associated value (an exceptional circumstance); or relocation is the only means of saving the structure; or

ii. relocation provides continuity of cultural heritage value.

iii. A new site should provide a setting compatible with cultural heritage value.

\section{Invasive Investigation}

Invasive investigation of a place can provide knowledge that is not likely to be gained from any other source. Archaeological or structural investigation can be justified where such evidence is about to be lost, or where knowledge may be significantly extended, or where it is necessary to establish the existence of material of cultural heritage value, or where it is necessary for conservation work. The examination should be carried out 
according to accepted scientific standards. Such investigation should leave the maximum amount of material undisturbed for study by future generations.

\section{Contents}

Where the contents of a place contribute to its cultural heritage value, they should be regarded as an integral part of the place and be conserved with it.

\section{Works of Art and Special Fabric}

Carving, painting, weaving, stained glass and other arts associated with a place should be considered integral with a place. Where it is necessary to carry out maintenance and repair of any such material, specialist conservation advice appropriate to the material should be sought.

\section{Records}

Records of the research and conservation of places of cultural heritage value should be placed in an appropriate archive. Some knowledge of place of indigenous heritage value is not a matter of public record, but is entrusted to guardians within the indigenous community.

\section{Conservation Processes}

\section{Degrees of Intervention}

Conservation may involve, in increasing extent of intervention: non-intervention, maintenance, stabilisation, repair, restoration, reconstruction or adaptation. Where appropriate, conservation processes may be applied to parts or components of a structure or site.

Re-creation, meaning the conjectural reconstruction of a place, and replication, meaning to make a copy of an existing place, are outside the scope of this charter.

\section{Non-intervention}

In some circumstances, assessment may show that any intervention is undesirable. In particular, undisturbed constancy of spiritual association may be more important than the physical aspects of some places of indigenous heritage value.

\section{Maintenance}

A place of cultural heritage value should be maintained regularly and according to a plan, 
except in circumstances where it may be appropriate for places to remain without intervention.

\section{Stabilisation}

Places of cultural heritage value should be protected from processes of decay, except where decay is appropriate to their value. Although deterioration cannot be totally prevented, it should be slowed by providing stabilisation or support.

\section{Repair}

Repair of material or of a site should be with original or similar materials. Repair of a technically higher standard than the original workmanship or materials may be justified where the life expectancy of the site or material is increased, the new material is compatible with the old and the cultural heritage value is not diminished. New material should be identifiable.

\section{Restoration}

Restoration should be based on respect for existing material and on the logical interpretation of all available evidence, so that the place is consistent with its earlier form and meaning. It should only be carried out if the cultural heritage value of the place is recovered or revealed by the process.

The restoration process typically involves reassembly and reinstatement and may involve the removal of accretions.

\section{Reconstruction}

Reconstruction is distinguished from restoration by the introduction of additional materials where loss has occurred. Reconstruction may be appropriate if it is essential to the function or understanding of a place, if sufficient physical and documentary evidence exists to minimise conjecture, and if surviving heritage valued are preserved. Reconstruction should not normally constitute the majority of a place. Generalised representations of typical features or structures should be avoided.

\section{Adaptation}

The conservation of a place of cultural heritage value is usually facilitated by it serving a socially, culturally or economically useful purpose. In some cases, alterations and additions amy be acceptable where they are essential to continued use, or where they are culturally desirable, or where the conservation of the place cannot otherwise be achieved. Any change, however, should be the minimum necessary and should not detract from the cultural heritage value of the place. Any conditions and alterations should be compatible with original fabric but should be sufficiently distinct that they can be read as new work. 


\section{Interpretation}

Interpretation of a place may be appropriate if enhancement of public understanding is required. Relevant protocol should be complied with. Any interpretation should not compromise the values, appearance, structure or materials of a place, or intrude upon the experience of the place. 


\section{United States of America}

\section{Charter for Historic Towns: A Preservation Charter for the Historic Towns and Areas of the United States of America (1992)}

Since the 1960's both the national and international preservation movements have stressed the importance of writing down the principles and practices of preservation. This began in the United States with the regulations that support the National Historic Preservation Act of 1966 and with the Secretary of the Interior's Standards for Historic Preservation Projects, based on the international Venice Charter of 1964. These documents were amplified in the following decades by such detailed conference reports as the National Trust's "Preservation: Toward an Ethic in the 1980s" and "A Vision for America: An Agenda for the Future", which came out of a 1986 conference at Mary Washington College. The practice of formalization has continued most recently with the National Trust's 1990 Charleston Principles; the 1992 New Orleans Charter for the Joint Preservation of Historic Structures and Artifacts, which was sponsored by the Association for Preservation Technology and the American Institute of Conservation; and the 1987 ICOMOS Historic Towns Charter, which is the basis for the United States version of the charter published here.

The 1987 ICOMOS Charter, which set forth preservation principles recognized as applicable throughout the civilized world, was adapted in 1992 by the US/ICOMOS Committee on Historic Towns to suit the specific nature of local government in the United States.

It sets forth a comprehensive statement about the importance of historic towns, neighborhoods, and places and states what must be done by communities in the United States that wish to tackle their preservation problems in a coherent, comprehensive way.

\section{Preamble:}

US/ICOMOS believes that the Washington Charter (the common name for the ICOMOS Charter on the Conservation of Historic Towns and Urban Areas [1987]), with some changes in language that make it more understandable to a United States audience of preservationists and public officials, will fill very well the need for a comprehensive, coherent statement of American preservation philosophy.

The Washington Charter was the result of twelve years of work and study by international specialists in various aspects of the ICOMOS General Assembly in Washington, D.C. The terms of the Charter are intentionally broad and recognize that when viewed from an international perspective, there are many approaches to the planning and protection of historic urban areas. The Charter recognizes this diversity. That the document had its origins in, and original application to, the more ancient cities of Europe does not diminish its potential usefulness or importance for application to the cities and historic areas of the United States of America, since the principles it espouses 
have been generally recognized as valid throughout the United States professional preservation community for many years.

What follows immediately below is a new version of this Charter, developed specifically for use in the United States of America. The full title of the new document is A Preservation Charter for the Historic Towns and Areas of the United States of America. The document may be cited by the short title, A Preservation Charter for the United States of America.

\section{Four Basic Objectives:}

The basic objectives of the preservation of historic towns and historic areas in the United States of America are:

The preservation of historic towns and historic districts or areas must be an integral part of every community's comprehensive planning process. All planning efforts-- plans for land use, economic development, housing, public utilities and facilities, transportation, recreation, housing and social services, open space, and urban design -- must incorporate historic preservation goals if they are to serve the needs of local inhabitants. This is also true of national, state, and regional planning efforts having a direct effect on local areas.

The significant features of a historic town or district include all of the physical and intangible or spiritual elements that go to make up its character. These elements include five special attributes:

1. The historic development patterns of the place, as these have emerged over time.

2. The special relationships between the buildings of the town or district, and its surrounding streetscape and landscape.

3. The physical attributes of the inside and outside of the buildings themselves. These include not only the main facade of a building, but its construction features, proportions, and interior spaces.

4. The major characteristics of an individual building to be preserved include its scale, materials, construction features, size, style, and ornamentation.

The unique relationship between the historic town or district and its larger surrounding area, whether the surrounding area is urban or rural.

The various functions that the historic district or neighborhood have acquired over time. These functions give it an overall ambience that along with other intangible elements combine to create or define its special character.

Any threat to any of these qualities compromises the authenticity of a historic town or district and is to be avoided absolutely, whether as a matter of public policy, private investment, or both. 
Property owners and residents are central to the process of protection and must have every opportunity to become democratically and actively involved in decisions affecting each historic town or district. Special attention must be given to basic human needs, which include affordable housing, personal safety and security, access to public services, and political participation as part of the overall historic preservation planning process. Historic towns and districts are of primary importance for those who live and work in them. This consideration must not be overlooked in preservation programs.

Historic preservation efforts in historic towns or districts must reflect a comprehensive and consistent set of standards and policies, adopted as consistent regulatory, investment, and operating policies by the local governing board. While these should follow generally accepted guidelines for professional practice, they must also be especially responsive to the particular needs or priorities of individual communities and their assets and their inhabitants. They must also be sufficiently flexible to meet the special needs of unusual or unique cultural resources and populations.

\section{Eighteen Basic Principles:}

A local preservation program must be based on the following measures:

1. Successful and realistic planning for the preservation of a historic town or district must be preceded by appropriate studies of the place itself. Typically these studies will include United States history and culture, architectural and landscape history, prehistory, and related fields. These studies establish the historic contexts of the place and insure that future public and private investment will be based on knowledge and reason rather than emotion. A well-conceived preservation plan must also address the future of the area. Such a plan must be based on appropriate economic, demographic, and land-use studies and projections.

2. The principal objectives of the preservation plan should be clearly stated in both verbal and graphic form, as should the legal, administrative, and financial measures needed to carry them out.

3. The preservation plan should aim to create and maintain a harmonious relationship between the historic area and its setting in the larger town, city, or region.

4. The preservation plan should determine which buildings, groups of buildings, sites and landscapes must be preserved, recognizing that what is worthy of preservation is an evolving concept.

5. Before any changes, including restoration, preservation, adaptive use, and/or conservation are made to individual structures or their settings, existing conditions must be thoroughly documented. 
6. The current residents of the historic area should be actively and continuously involved in the planning process. They should have access to all necessary information. Their reactions and comments to all public and private proposals for the area should be actively sought.

7. Until a preservation plan has been adopted, and as an interim measure, any necessary preservation work should be carried out in accordance with the objectives and principles outlined here. Such work should also be in conformity with the Venice Charter and other relevant ICOMOS and UNESCO recommendations and charters.

8. Local, state, and national governments must recognize that the continuing maintenance of both public and private property and the economic well-being of the inhabitants are essential to the effective preservation of any historic place.

9. New functions and activities proposed to take place within the historic town or district should be compatible with the overall character of the place. When historic places and buildings are adapted for contemporary use, it is essential that the design, installation, and maintenance of supporting public utilities and facilities be sensitive to the special character of the place.

10. The improvement of housing, the retention of affordable housing, and the avoidance of wholesale displacement of existing residents should be among the basis policy objectives of a preservation plan.

11. When it is necessary to construct new buildings or to adapt existing ones, the existing scale and spatial structure of the place must be respected, as well as the relationship of each building or place to its larger setting. The introduction of appropriate contemporary design, in harmony with its surroundings, should not be discouraged. Such contemporary additions, when appropriately designed, enrich and enliven a historic area and provide as well a measure of cultural continuity.

12. When appropriate, knowledge of the history of a given area should be expanded through continuing programs of archaeological investigation, and through the presentation and preservation of archaeological findings and artifacts.

13. Traffic and transportation inside a historic area must be controlled and must respect the historic environment. It is essential that parking areas be designed in ways that do not cause aesthetic or functional damage to any historic structure, group of buildings, sites, landscapes, or the general environment.

14. When major roads and transit systems are planned or built, they must not penetrate or divide a historic area, but should improve access to it. Transportation and utility corridors and other public works within the historic area must be designed and constructed to cause the least possible damage to historic structures, groups, sites, or landscapes or to the setting of the whole area. 
15. To maintain both the physical heritage and the security and well-being of residents, historic areas should be protected insofar as possible against natural disasters, pollution, nuisances, and other harmful intrusions. Whether in laying plans for the protection of a historic area from disaster or in its aftermath, preventive and repair measures must be adapted to the specific character of the area and its component parts.

16. In order to encourage residents to participate in preservation activities and to enhance the local climate for preservation, continuing general information and educational programs should be established. This effort must begin with heritage education programs for children of school age. Specialized training should be provided for all those professions actively involved with preservation, as well as for public officials, volunteers, and volunteer organizations.

17. The creation and support of appropriate preservation organizations should be encouraged.

18. An appropriate variety of preservation-related financial incentives should be identified. Their development should be encouraged by governments, private businesses, and individuals. 


\section{Canada}

\section{The Appleton Charter for the Protection and Enhancement of the Built Environment (1983)}

Published by ICOMOS Canada under the auspices of the English-Speaking Committee, Ottawa, Canada, August 1983

\section{A. Preamble}

This charter acknowledges The International Charter for the Conservation \& Restoration of Monuments \& Sites (Venice, 1964), the Australia ICOMOS Charter for the Conservation of Places of Cultural Significance (the Burra Charter of February 23, 1981), and the Charter for the Preservation of Quebec's Heritage (Declaration of Deschambault), without which it could not exist.

It further recognizes that the sound management of the built environment is an important cultural activity; and that conservation is an essential component of the management process.

\section{B. Framework}

Intervention within the built environment may occur at many levels (from preservation to redevelopment), at many scales (from individual building elements to entire sites), and will be characterized by one or more activities, ranging from maintenance to addition.

Though any given project may combine intervention scales, levels and activities, projects should be characterized by a clearly stated goal against which small scale decisions may be measured.

The appropriate level of intervention can only be chosen after careful consideration of the merits of the following: cultural significance, condition and integrity of the fabric, contextual value, appropriate use of available physical, social and economic resources.

Decisions concerning the relative importance of these factors must represent as broadly based a consensus as possible. Legitimate consensus will involve public participation and must precede initiation of work. The relationship between scales of intervention levels of intervention and intervention activities is summarized below. 


\section{Activity}

Levels of Maintenance Stabilization Removal Addition

Intervention:

$\begin{array}{lll}\text { Preservation } & \mathrm{X}\end{array}$

Period

Restoration

$\mathrm{X} \quad \mathrm{X}$

Rehabilitation

$\mathrm{X}$

$\mathbf{x}$

Period

Reconstruction

Redevelopment

$\mathbf{X} \quad \mathrm{X} \quad \mathrm{X}$

$\mathrm{x} \quad \mathrm{x}$

$\mathbf{x}$

$\mathrm{x} \quad \mathrm{x}$

$\mathrm{X}$

$\mathrm{X}$

\section{Scales of intervention}

\section{Levels of \\ Intervention: Elements \\ Bldgs Groups Bldgs Sites \\ of $\quad \&$ \\ Buildings Settings}

Preservation

$\mathbf{X}$

$\mathrm{x}$

$\mathrm{X}$

$\mathrm{x}$

$\mathrm{x}$

Period

Restoration

Rehabilitation

$\mathrm{X}$

X

$\mathrm{X}$

$\mathrm{x} \quad \mathrm{x}$

Period

Reconstruction

$\mathbf{X}$

$\mathbf{X}$

$\mathrm{X}$

X $\quad \mathrm{X}$

Redevelopment

$\mathrm{X}$

$\mathrm{X}$

$\mathrm{X}$

$\mathrm{X}$

$\mathbf{x}$

Levels of intervention:

Preservation:

- retention of the existing form, material and integrity of site.

Period Restoration:

- recovery of an earlier form, material and integrity of a site.

\section{Rehabilitation:}

- modification of a resource to contemporary functional standards which may involve adaptation for new use. 
Period Reconstruction:

- recreation of vanished or irreversibly deteriorated resources.

Redevelopment:

- insertion of contemporary structures or additions sympathetic to the setting.

Activities:

Maintenance:

- continual activity to ensure the longevity of the resource without irreversible or damaging intervention.

\section{Stabilization:}

- a periodic activity to halt deterioration and to put the existing form and materials of a site into a state of equilibrium, with minimal change.

\section{Removal:}

- a periodic activity: modification which involves the subtraction of surfaces, layers, volumes and/or elements.

\section{Addition:}

- a periodic activity: modification which involves the introduction of new material.

\section{Principles}

Respect for the existing fabric is fundamental to the activities of protection and enhancement.

The process of protection and enhancement must recognize all interests and have recourse to all fields of expertise which can contribute to the study and safeguarding of a resource.

In intervening at the scales, levels and activities described, measures in support of the protection and enhancement of the built environment will involve adherence to the following principles:

\section{Protection:}

- Protection may involve stabilization; it must involve a continuing programme of maintenance.

\section{Artifactual value:}

- Sites of the highest cultural significance are to be considered primarily as artifacts, demanding protection as fragile and complex historical monuments. 


\section{Setting:}

- Any element of the built environment is inseparable from the history to which it bears witness, and from the setting in which it occurs. Consequently, all interventions must deal with the whole as well as with the parts.

\section{Relocation:}

- Relocation and dismantling of an existing resource should be employed only as a last resort, if protection cannot be achieved by any other means.

\section{Enhancement:}

- The activities of removal or addition are characteristic of measures in support of enhancement of the heritage resource.

\section{Use:}

- A property should be used for its originally intended purpose. If this is not feasible, every reasonable effort shall be made to provide a compatible use which requires minimal alteration.

- Consideration of new use should begin with respect for existing and original traditional patterns of movement and layout.

\section{Additions:}

- New volumes, materials and finishes may be required to satisfy new uses or requirements. They should echo contemporary ideas but respect and enhance the spirit of the original.

\section{Environmental Control:}

- Systems of insulation, environmental control and other servicing should be upgraded in ways which respect the existing and traditional equilibria and do not set in motion processes of deterioration.

\section{Practice}

\section{Documentation:}

- The better a resource is understood and interpreted, the better it will be protected and enhanced.

- In order to properly understand and interpret a site, there must be a comprehensive investigation of all those qualities which invest a structure with significance.

- This activity must precede activity at the site. Work on site must itself be documented and recorded.

\section{Conjecture:}

- Activities which involve the recovery or recreation of earlier forms must be limited to those forms which can be achieved without conjecture. 


\section{Distinguishability:}

- New work should be identifiable on close inspection or to the trained eye, but should not impair the aesthetic integrity or coherence of the whole.

\section{Materials and techniques:}

- Materials and techniques should respect traditional practice unless modern substitutes for which a firm scientific basis exists, which have been supported by a body of experience and which provide significant advantage can be identified.

\section{Patina:}

- Patina forms part of the historic integrity of a resource, and its destruction should be allowed only when essential to the protection of the fabric. Falsification of patina should be avoided.

\section{Reversibility:}

- The use of reversible processes is always to be preferred to allow the widest options for future development or the correction of unforeseen problems, or where the integrity of the resource could be affected.

\section{Integrity:}

- Structural and technological integrity must be respected and will require attention to performance as well as to appearance. 


\section{References}

Archaeological Institute of America.

2006 Glossary. Available online < http://www.archaeological.org/webinfo.php?page=10299\#r $>$, Accessed January 20, 2007.

Bell, J and C. Ouimet.

2004 "Tailoring the Heritage Record. A Proactive Approach to Users Needs." New Perspectives to Save Cultural Heritage, CIPA 2003 XIXth International Symposium, Antalya, Turkey. Available online $<$ http://cipa.icomos.org/fileadmin/papers/antalya/184.pdf >, Accessed November 6, 2006.

Bennett, Gordon.

2006 Personal Communication, March 29, Ottawa, Ontario.

Brown, Robert Craig.

1969 "The Doctrine of Usefulness: Natural Resource and National Park Policy in Canada, 1887-1914," in Canadian Parks in Perspective, Harvest House Ltd. Quebec, Canada. 46-62

Burns, Robert J.

1979 Fort Wellington: A Narrative and Structural History 1812-38. Manuscript Report Number 296, Parks Canada, Ottawa, Ontario.

Cary, Henry.

2003 Archaeology at Fort Henry, 2003. From the library of Henry Cary, Unpublished.

2004 Early Works at Point Henry: Recent Research on the 1812-1842 Defences of Fort Henry, Kingston. CNEHA Conference Presentation, Kingston, Ontario. From the library of Henry Cary, Unpublished.

2005 First Fort and Redoubt. Parks Canada Archaeological Services, Military Sites Unit, Ontario Service Centre, Cornwall, Ontario.

Cary, Henry and Joseph Last.

2002 Fort Henry National Historic Site 2001 Archaeological Investigations on the Entrance Ramp's West Retaining and Counterscarp Walls. Parks Canada, Ontario Service Centre, Cornwall, Ontario.

2004 Archaeology at Fort Henry: The Advanced Battery. Parks Canada, Ontario Service Centre, Cornwall, Ontario.

Coleman, Karalee.

1966 "Report on Excavations at Fort Wellington, Prescott, Ontario," in Miscellaneous Reports of Fort Wellington, Ontario. Manuscript Report Number 130. By the 
Department of Indian and Northern Affairs, Parks Canada, National Parks and Sites Branch. Date unknown, pp. 77-119.

Department of Finance, Canada.

2005 Budget 2005 - Budget Plan, Chapter 3: Securing Canada's Social Foundations. Available Online < http://www.fin.gc.ca/budget05/bp/bpc3e.htm >, Accessed July 19, 2005.

2006 Budget 2006-Budget Plan. Available online < http://www.fin.gc.ca/budget06/bp/bptoce.htm >, Accessed August 23, 2006.

Department of Mines and Resources, Canada.

Undated (circa. 1936-1949) ${ }^{41}$ Guide to Fort Wellington and Vicinity, Prescott, Ontario. Lands, Parks and Forests Branch. Republished in Interpretive Resource Inventory: Fort Wellington National Historic Park, Prescott, Ontario. By Louis J. Flynn, 1976, pp. 34-37.

Duffy, Christopher.

1975 Fire and Stone: The Science of Warfare 1660-1860. Douglas David \& Charles Limited, Vancouver, British Columbia.

Dykman, James and Lawrence B. De Graff.

1987 "Cultural Resource Management: Caring for Culture's Clutter in the Bureau of Land Management and the National Park Service," in The Public.Historian, Vol. 1, No. 2 (Spring), pp. 154-159.

Ferris, Neal.

1998 "I don't think we're in Kansas anymore...": The rise of the archaeological consulting industry in Ontario. Archaeology \& Heritage Planning, Ministry of Citizenship, Culture \& Recreation. Available online at

$<$ http://www.adamsheritage.com/articles/neal/neal.htm >, Accessed on January 24, 2006.

Flynn, Louis J.

1967 Excerpt from: "Prescott, 1810-1967," The Cardinal News, Prescott. Republished in Interpretive Resource Inventory: Fort Wellington National Historic Park, Prescott, Ontario. By Louis J. Flynn, 1976, pp. 24-27.

1976 Interpretive Resource Inventory: Fort Wellington National Historic Park, Prescott, Ontario. Parks Canada, Ontario Region.

\footnotetext{
${ }^{41}$ Although this document is undated, The Department of Mines and Resources was created in 1936 and was replaced by the Department of Mines and Technical Surveys by 1949 (Natural Resources Canada, 2006).
} 
Garcia, Bob.

2003 Underground Drainage at Fort Henry, Vol. 1. Parks Canada, Ontario Service Centre, Cornwall, Ontario.

Goldring, Philip.

2006 Personal Communication, March 30, Ottawa, Ontario.

Hargrove, Cheryl M.

2002 "Heritage Tourism," in CRM (Cultural Resource Management), Vol. 25 (1). pp. 10-11.

Historic Sites and Monuments Board of Canada.

1979 Recognizing Canadian history: the historic sites and monuments board of Canada. Parks Canada, Ottawa, Ontario.

2003 About the Historic Sites and Monuments Board of Canada: History of the Board. Available online < http://www.pc.gc.ca/clmhc-hsmbc/clmhc-hsmbc/clmhc-hsmbcl_E.asp >, Accessed August 24, 2006.

2004 About the Historic Sites and Monuments Board of Canada: Introduction. Available online < http://www.pc.gc.ca/clmhc-hsmbc/clmhc-hsmbc/index_E.asp >, Accessed August 24, 2006.

Hogg, Ian V.

1975 Fortress: A History of Military Defence. Macdonald and Jane's, London, UK.

House of Commons,

1998 The Parks Canada Agency Act. Available online at < http://laws.justice.gc.ca/en/P0.4/text.html >, Accessed August 25, 2006.

2005 Bill C-7: An Act to amend the Department of Canadian Heritage Act and the Parks Canada Agency Act and to make related amendments to other Acts. 38th Parliament, 1st Session. Available online at $<$ http://www.parl.gc.ca/38/1/parlbus/chambus/house/debates/033_2004-11-26/han033_1000E.htm\#PT-1 >, Accessed August 25, 2006.

ICOMOS.

1990 The ICOMOS Charter for the Protection and Management of the Archaeological Heritage. Available online < http://www.international.icomos.org/e_archae.htm >, Accessed November 20, 2006.

ICOMOS Australia.

1999 The Burra Charter: The Australia ICOMOS charter for the conservation of places of cultural significance. Available online < http://www.icomos.org/australia/burra.html >, Accessed November 20, 2006. 
ICOMOS Canada.

1983 Appleton Charter for the Protection and Enhancement of the Built Environment. Available online $<\mathrm{http}: / / \mathrm{www}$.international.icomos.org/charters/appleton.pdf $>$, Accessed November 20, 2006.

ICOMOS United States of America.

1992 The Preservation Charter for the Historic Towns and Areas of the United States of America. US/ICOMOS Committee on Historic Towns.

ICOMOS New Zealand.

1992 Charter for the Conservation of Places of Cultural Heritage Value. Available online $<\mathrm{http}: / /$ www.icomos.org/docs/nz_92charter.html $>$, Accessed November 20, 2006.

Jones, K.L., D. Harlow and D.S. Gosling.

2002 Caring for archaeological sites: New Zealand guidelines. Available online < http://www.doc.govt.nz/Publications/004 Science-andResearch/Miscellaneous/PDF/ArchSitesA.pdf >, Accessed November 21, 2006.

Karamanski, Theodore J.

1980 "History as an Empowering Force in Cultural Resource Management," in The Public Historian, Vol. 2, No. 3, Spring. pp. 71-76.

Kelley, Jane H., and Ronald F. Williamson.

1996 "The Positioning of Archaeology within Anthropology: A Canadian Historical Perspective" in American Antiquity, Vol. 61(1), pp. 5-20.

Killan, Gerald.

1980 "The Canadian Institute and the Origins of the Ontario Archaeological Tradition, 1851-1884" in Ontario Archaeology, Vol. 34, pp. 3-16.

King, Thomas F.

1976 "Public Archaeology" in American Antiquity, Vol. 41, No. 2 (April), pp. 236-238.

2002 Thinking About Cultural Resource Management: Essays from the Edge. (Altamira Press, California).

Last, Joseph.

2006 Personal Communication, September 15, Cornwall, Ontario.

Lee, Ellen.

2007 Personal Communication, January 12, Gatineau, Quebec.

Lipe, William D.

1974 "A Conservation Model for American Archaeology," The Kiva 39, no. 1-2 (1974): 213-243. 
Lipe, William D. and Alexander J. Lindsay, Jr.

1974 "Introduction," in Proceedings of the 1974 Cultural Resource Management Conference, Denver, Colorado. ed. William D. Lipe and Alexander J. Lindsay, Jr. The Northern Arizona Society of Science and Art, Inc. Flagstaff, Arizona. pp. viixiii.

Lyon, Elizabeth A.

1982 "Cultural and Environmental Resource Management: the Role of History in Historic Preservation," in The Public Historian, Vol. 4, No. 4, Fall. pp. 69-86.

MacDonald, George.

1976 "Prehistoric Archaeology in Canada" in New Perspectives in Canadian Archaeology: Fifteenth Symposium. (ed. A.G. McKay) The Royal Society of Canada, Ottawa, Ontario. pp. 73-81.

Mathers, Clay, Timothy Darvill and Barbara J. Little.

2005a Heritage of Value, Archaeology of Renown: Reshaping Archaeological Assessment and Significance, University Press of Florida, Gainsville.

2005b "Introduction: Archaeological value in a world context," in Heritage of Value, Archaeology of Renown: Reshaping Archaeological Assessment and Significance, University Press of Florida, Gainsville. pp. 1-21

Marion, Bob

Date unknown

Archaeology at Fort Henry, 2002-2003: PowerPoint Presentation. From the personal library of Henry Cary, Parks Canada, Ontario Service Centre, Cornwall, Ontario.

Marsh, John S.

1969 "Maintaining the Wilderness Experience in Canada's National Parks," in Canadian Parks in Perspective, Harvest House Ltd. Quebec, Canada. 123-136

Marsters, Roger S.

2004 John Clarence Webster and Bicultural Nationalism: Language, Ethnicity and the Politics of Commemoration in Early Twentieth-Century Canada. Masters Thesis, Dalhousie University, Nova Scotia.

McKenna, Katherine, M. J.

1995 Family Life in a Military Garrison: History of the Routines and Activities of the Royal Canadian Rifle Regiment at Fort Wellington, Prescott, 1843-1854. Microfiche Report Series Number 533, Parks Canada, Department of Canadian Heritage, Hull, Quebec. 
McManamon, Francis, $\mathrm{P}$.

2000 "The protection of archaeological resources in the United States: reconciling preservation with contemporary society" in Cultural Resource Management in Contemporary Society: Perspectives on Managing and Presenting the Past, ed. Francis P. McManamon and Alf Hatton. Routledge, London. pp. 40-55.

Minnesota State University.

2003 A History of Latin America Archaeology. Available online < http://www.mnsu.edu/emuseum/prehistory/latinamerica/topics/history.html >, Accessed January 20, 2007.

National Parks Service (NPS), Department of the Interior, United States of America.

1992 The Secretary of the Interior's Standards for the Treatment of Historic Properties. Available online < http://www.cr.nps.gov/hps/tps/standguide/index.htm $>$, Accessed November 22, 2006.

2006a Archeology Program: Managing Archeological Collections Glossary. Available online < http://www.cr.nps.gov/archeology/collections/glossary.htm >, Accessed November $1,2006$.

2006b Management Policies: The Guide to Managing the National Park System. Available online <http://www.nps.gov/policy/MP2006.pdf >, Accessed November 22, 2006.

Natural Resources Canada.

2006 The Evolution of NRCan. Available online < http://www.nrcan.gc.ca/inter/factsheets 10ya/evolution_e.html >, Accessed October 20, 2006.

New York State Division of Military and Naval Affairs.

2006 Forts: Glossary of Terms. Available online at $<$ http://www.dmna.state.ny.us/forts/glossary/glossary.htm >, Accessed November 1, 2006.

New South Wales National Parks and Wildlife Service (Australia).

1997 "Standards For Archaeological Practice in Aboriginal Heritage Management" in Aboriginal Cultural Heritage Standards \& Guidelines Kit. Available online < http://www.nationalparks.nsw.gov.au/pdfs/aboriginal_heritage_guidelines_kit_final.pdf $>$, Accessed November 20, 2006.

Noble, William C.

1972 "One Hundred and Twenty-five Years of Archaeology in the Canadian Provinces" in Canadian Archaeological Association Bulletin, Vol. 4, pp. 1-78.

Novak, Melissa E.

2006a Photographs from Fort Henry National Historic Site. September 10, Kingston, Ontario. 
2006b Photographs from Fort Wellington National Historic Site. September 28, Prescott, Ontario.

Office of the Auditor General of Canada.

2003 Report of the Auditor General of Canada, November Report, Chapter 6:

Protection of Cultural Heritage in the Federal Government. Available Online < http://www.oag-bvg.gc.ca/domino/media.nsf/html/20031 106pr_e.html >, Accessed July 19, 2005.

Parks Canada.

1994a Parks Canada Guiding Principles and Operational Policies. Department of Canadian Heritage, Hull, Quebec.

1994b "Cultural Resource Management Policy," in Parks Canada Guiding Principles and Operational Policies. Department of Canadian Heritage, Hull, Quebec. $p p$. 99-123.

1996 Fort Henry National Historic Site Commemorative Integrity Statement. Department of Canadian Heritage, Hull, Quebec.

Parks Canada Agency.

1998 Kingston Fortifications National Historic Site Commemorative Integrity Statement. Government of Canada, Ottawa, Canada.

1999 Press Release, April 16: Eggleton and Mitchell announce new measures for the preservation of Fort Henry National Historic Site. Available online $<$ http://www.pc.gc.ca/apps/cp-nr/release_e.asp?id=12\&andor $1=n r>$, Accessed September 27, 2006.

2001 Fort Wellington \& the Battle of the Windmill National Historic Sites of Canada Management Plan. Government of Canada, Ottawa, Canada.

2002a Parks Canada Charter. Available online < http://www.pc.gc.ca/agen/chart/chartr_E.asp $>$, Accessed August 28, 2006.

2002b Press Release, November 22: Restoration Work at Fort Henry National Historic Site of Canada. Available online $<$ http://www.pc.gc.ca/apps/cp$\mathrm{nr} /$ release_e.asp?id=651\&andor $1=\mathrm{nr}>$, Accessed September 27, 2006.

2003a Standards and Guidelines for the Conservation of Historic Places in Canada. Available online

$<$ http://www.parkscanada.pch.gc.ca/docs/pc/guide/nldclpc-sgchpc/index_E.asp >, Accessed July 19, 2005. 
2003b Minister's Round Table on Parks Canada-Pre-reading Material. Available online < http://www.pc.gc.ca/agen/trm-mrt/2005/itm4-/table4a_e.asp\#note >, Accessed December 10. 2005.

2003c National Historic Sites of Canada. Available online < http://www.pc.gc.ca/progs/lhnnhs/intro_e.asp >, Accessed December 12, 2005.

2003d Press Release, December 22: Government of Canada Announces Contract for Stabilization Work at Fort Henry National Historic Site of Canada. Available online $<$ http://www.pc.gc.ca/apps/cp-nr/release_e.asp?id=756\&andorl=nr $>$, Accessed September 27, 2006.

2003e State of Protected Heritage Areas - Heritage Renewal. Available online $<$ http://www.pc.gc.ca/docs/pc/rpts/heritage/prot72_e.asp >, Accessed December 22, 2005.

2004a National Marine Conservation Areas of Canada. Available online $<$ http://www.pc.gc.ca/progs/amnc-nmca/index_E.asp >, Accessed September 5, 2006.

2004b "Part III - Report on Plans and Priorities", in Parks Canada 2004/05 Estimates. Canadian Government Publishing, Ottawa, Ontario.

2004c Press Release, September 23: Government of Canada Announces Contract for Stabilization Work at Fort Henry National Historic Site of Canada. Available online $<\mathrm{http}: / / \mathrm{www} . \mathrm{pc} . \mathrm{gc} . \mathrm{ca} / \mathrm{apps} / \mathrm{cp}-\mathrm{nr} /$ release_e.asp?id=837\&andor $1=\mathrm{nr}>$, Accessed September 27, 2006.

2005a Archaeology at Parks Canada. Available online < http://www.pc.gc.ca/progs/pfafap/itm4-/arch4_e.asp >, Accessed November 22, 2006.

2005bJobs@Parks Canada. Available online < http://www.pc.gc.ca/agen/empl/index_e.asp $>$, Accessed December 12, 2005.

2005c National Parks of Canada. Available online < http://www.pc.gc.ca/progs/nppn/index_E.asp >, Accessed September 5, 2006.

2006 Directory of Designations of National Historic Significance in Canada. Available online < http://www.pc.gc.ca/apps//hn-nhs/index_e.asp $>$ Accessed November $8,2006$.

Parks of the St. Lawrence.

2004 "History Overview," at FortHenry.com < http://www.forthenry.com/pasthist.htm >, Accessed September 29, 2006.

Renfrew, Colin and Paul Bahn.

1996 Archaeology: Theories, Methods, Practice. Douglas \& McIntyre, Vancouver, British Columbia. 
Rick, Anne M.

1994 The Privy Speaks: A Study of Status and Gender from Animal Remains at Fort Wellington, Ontario, 1994 Revision. Zooarchaeological Analysis Programme, Canadian Museum of Nature, Ottawa, Ontario.

Robinson, Willard B.

1977 American Forts: Architectural Form and Function. University of Illinois Press, Urbana, USA.

Rutch, Edwards S. and Kim M. Peters

1977 "Forty Years of Archaeological Research at Morristown National Historical Park, Morristown, New Jersey" in Historical Archaeology, Vol. 11. pp. 15-39.

Sabloff, Jeremy A.

1978 "Editor's Corner" in American Antiquity, Vol. 43, No. 4 (October), pp. 551-552.

Schiffer, Michael B. and John H. House.

1977 "Cultural Resource Management and Archaeological Research: The Cache Project" in Current Anthropology, Vol. 18, No. 1 (March), pp. 43-68.

Scovill, Douglas H.

1974 "History of Archaeological Conservation Policy and the Moss-Bennett Bill," in the Proceedings of the 1974 Cultural Resource Management Conference, Denver, Colorado. ed. William D. Lipe and Alexander J. Lindsay, Jr. The Northern Arizona Society of Science and Art, Inc. Flagstaff, Arizona. pp. 1-11.

Stine, Jeffery K.

1992 "The Tennessee-Tombigbee Waterway and the Evolution of Cultural Resource Management," in The Public Historian, Vol. 14, No. 2 (Spring). pp. 7-30.

Sussman, Lynne.

1994 "Fine Ceramics from the RCRR Layers of the Latrine at Fort Wellington," in Material Culture of the Royal Canadian Rifle Regiment: Artifacts found in the Latrine at Fort Wellington, Prescott. Parks Canada, National Historic Sites, Department of Canadian Heritage, Hull, Quebec. pp. 193-264.

Taylor, C.J.

1990 Negotiating the past; the making of Canada's National Historic Parks and Sites. Montreal, McGill-Queen's University Press.

Taylor, W.E., Jr.

1976 "Fourth Session Introduction: Archaeology, New Motivations and Attitudes," in New Perspectives in Canadian Archaeology, (ed. A.G. McKay) The Royal Society of Canada, Ottawa, Ontario. pp. 151-159. 
Thomas, Gerald Arthur.

1990 John Clarence Webster: The Evolution and Motivation of an Historian 19221950. Masters Thesis, University of New Brunswick.

Trigger, Bruce G.

1978 "Giants and Pygmies: The Professionalization of Canadian Archaeology" in Towards a History of Archaeology (ed. G. Daniel) Thames and Hudson, London. pp. 69-84.

1979 "Sixteenth Century Ontario: History, Ethnohistory, and Archaeology" in Ontario History, Vol. 71(4), pp. 205-223.

Turnbull, C.

1976 "Of Backdirt and Bureaucracy: The Role of Government in Canadian Archaeology" in New Perspectives in Canadian Archaeology: Fifteenth Symposium. (ed. A.G. McKay) The Royal Society of Canada, Ottawa, Ontario. pp. 119-136.

University of Manitoba, Department of Anthropology.

2006 A Glossary of Manitoba Prehistoric Archaeology. Available online < http://www.umanitoba.ca/anthropology/manarchnet/appendices/glossary.html\#letter\%20p >, Accessed, January 20, 2007.

Williamson, Ronald F.

2000 "Trends and Issues in Consulting Archaeology," in the Canadian Journal of Archaeology, Vol. 24. pp. 158-162.

Wright, J.V.

1985 "Development of Prehistory in Canada, 1935- 1985" in American Antiquity, Vol. 50(2). pp. 421-433.

Wylie, E.A.

1968 "Fort Wellington Excavations, 1968," in Miscellaneous Reports of Fort Wellington, Ontario. Manuscript Report Number 130. By the Department of Indian and Northern Affairs, Parks Canada, National Parks and Sites Branch. Date unknown, $p p$. 285-302. 